Florida International University

FIU Digital Commons

6-28-2019

\title{
Evaluation of Pre-eruptive Conditions for Cordon Caulle Rhyo- Dacitic Historic Eruptions
}

Mauro Andres Mingo

Florida International University, mming007@fiu.edu

Follow this and additional works at: https://digitalcommons.fiu.edu/etd

Part of the Geochemistry Commons, and the Volcanology Commons

\section{Recommended Citation}

Mingo, Mauro Andres, "Evaluation of Pre-eruptive Conditions for Cordon Caulle Rhyo-Dacitic Historic Eruptions" (2019). FIU Electronic Theses and Dissertations. 4228.

https://digitalcommons.fiu.edu/etd/4228

This work is brought to you for free and open access by the University Graduate School at FIU Digital Commons. It has been accepted for inclusion in FIU Electronic Theses and Dissertations by an authorized administrator of FIU Digital Commons. For more information, please contact dcc@fiu.edu. 


\title{
FLORIDA INTERNATIONAL UNIVERSITY
}

\author{
Miami, Florida
}

\section{EVALUATION OF PRE-ERUPTIVE CONDITIONS FOR CORDON CAULLE RHYO-DACITIC HISTORIC ERUPTIONS}

\author{
A thesis submitted in partial fulfillment of \\ the requirements for the degree of \\ MASTER OF SCIENCE \\ in \\ GEOSCIENCES \\ by \\ Mauro Andres Mingo
}


To: Dean Michael R. Heithaus

College of Arts, Sciences and Education

This thesis, written by Mauro Andres Mingo, and entitled Evaluation of Pre-eruptive Conditions for Cordon Caulle Rhyo-dacitic Historic Eruptions, having been approved in respect to style and intellectual content, is referred to you for judgment.

We have read this thesis and recommend that it be approved.

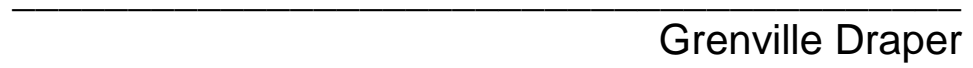

Grenville Draper

Andrew Macfarlane

Rosemary Hickey-Vargas, Major Professor

Date of Defense: June 28, 2019

The thesis of Mauro Andres Mingo is approved.

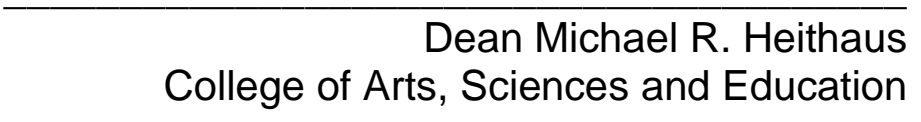

Dean Michael R. Heithaus

College of Arts, Sciences and Education

Florida International University, 2019

Andrés G. Gil

Vice President for Research and Economic Development and Dean of the University Graduate School 


\section{ACKNOWLEDGMENTS}

This process of the thesis has been a life changing opportunity and could not have being possible without the incredible help I have received. I would like to give my acknowledgment to the following people/institutions:

1) I would like to give my deepest thanks to Bec.ar Fulbright commission of Argentina, they have believed, invested and helped through all this process. 2) I would like to express my gratitude to my advisor Rosemary Hickey-Vargas who believed in me from day one and guided me throughout all this process being very engaged in my research and giving me the most valuable feedback. 3) I would like to thank Thomas Beasley, the head of the Electron Microscopy lab of FIU that without his help the present study would not have being possible. 4) I would also like to thank my committee members Dr. Draper and Dr. Macfarlane, both of whom were always predisposed to give feedback and correct my mistakes.

5) To all the staff at FIU that have being very welcoming of my stay in this incredible university.

6) To the National University of La Plata and specially the Igneous petrology staff that supported my stay in this new experience.

7) To my family and friends (old and new ones) that gave me incredible moral support to facilitate my stay long away from home. 


\title{
ABSTRACT OF THE THESIS \\ EVALUATION OF PRE-ERUPTIVE CONDITIONS FOR CORDON CAULLE RHYO-DACITIC HISTORIC ERUPTIONS
}

\author{
by \\ Mauro Andres Mingo \\ Florida International University, 2019 \\ Miami, Florida \\ Professor Rosemary Hickey-Vargas, Major Professor
}

For better understanding of Plinian-hybrid eruptive events, I analyzed the variables that affect the pre-eruptive conditions of the latest three eruptive events of the Puyehue Cordon Caulle Volcanic Complex (PCCVC). The analysis was done by performing a petrological study of lava samples followed by Electron Probe Microanalysis (EPMA) on selected mineral phases. Mineral data were then used in established mathematical models to calculate pre-eruptive magma temperature and water content. The acquired data are compared to bulk measured water content, and the difference is utilized to estimate viscosities and evaluate the degassing regime. Results indicate that the historic eruptive events have similar bulk composition and pre-eruptive variables; the 2011 event has slightly lower temperature and higher water content. However, the differences do not suggest that the eruptive style varies in accordance with the variable changes but instead is controlled by external factors such as the regional tectonic regime. The influence of deep heat source is also possible. 


\section{TABLE OF CONTENTS}

CHAPTER

PAGE

1. Introduction.

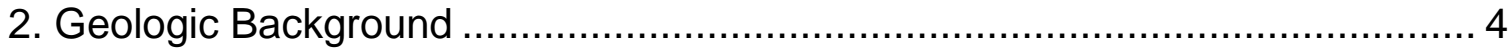

2.1. The Southern Volcanic Zone (SVZ) ................................................ 4

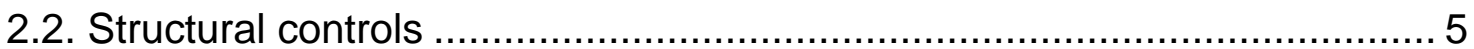

2.3. Puyehue Cordon Caulle Volcanic Complex (PCCVC) .............................. 6

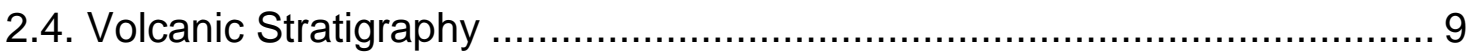

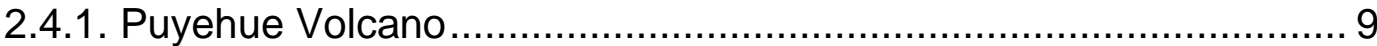

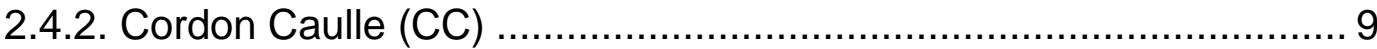

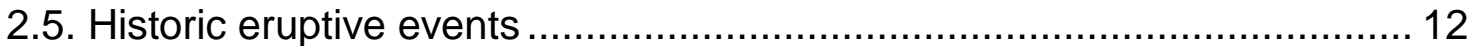

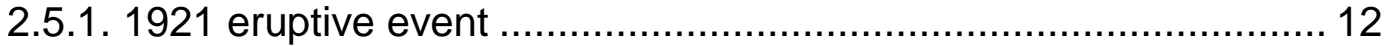

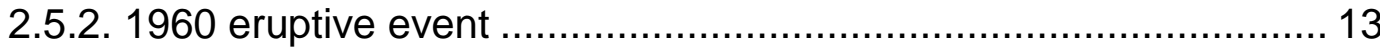

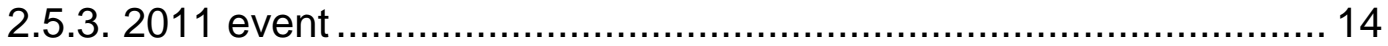

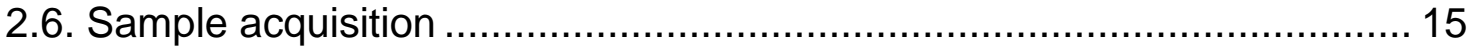

3. Background on methods used to determine pre-eruptive variables.............. 15

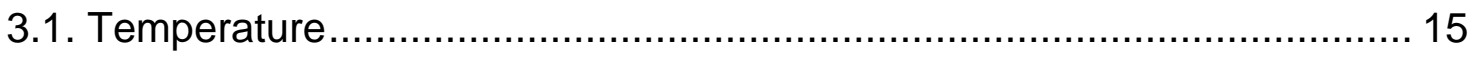

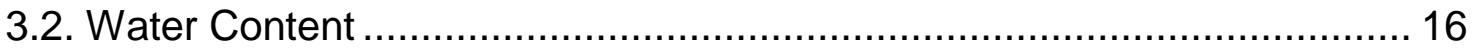

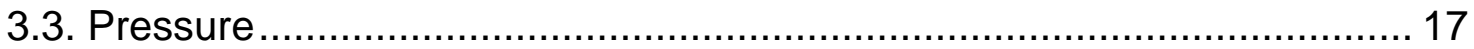

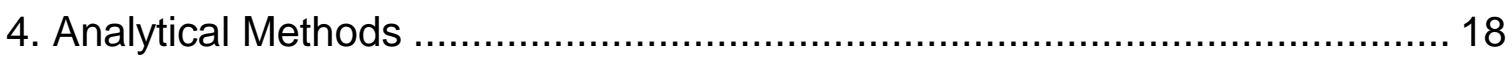

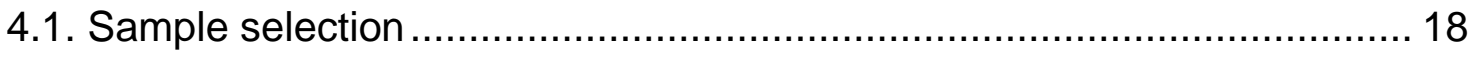

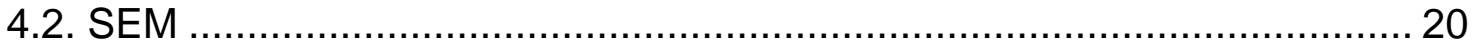

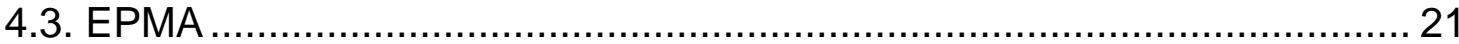

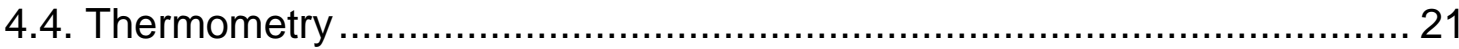

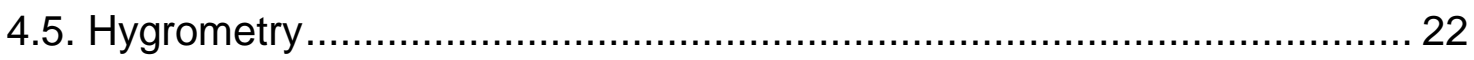

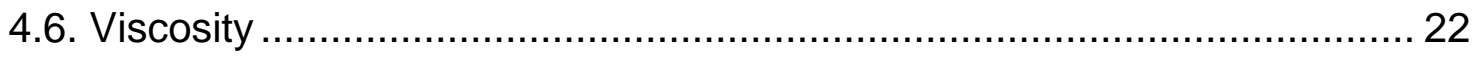

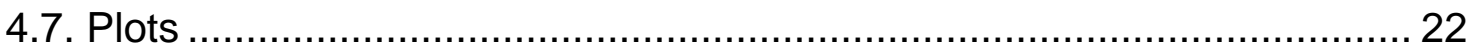

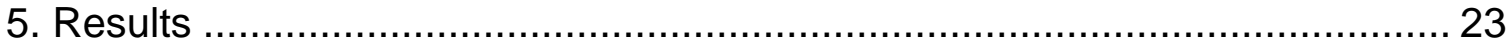

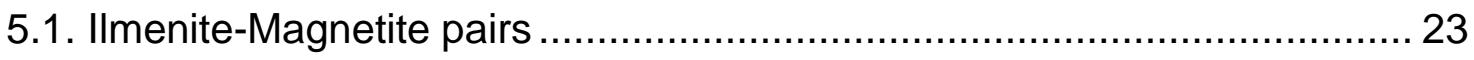




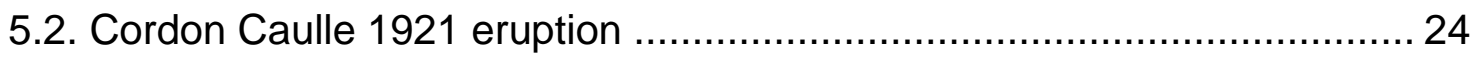

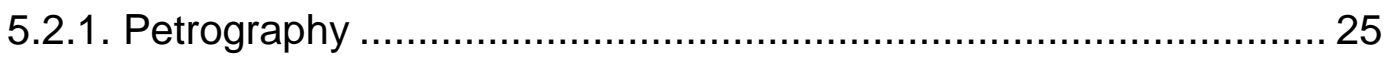

5.2.2. Geochemistry and Mineral Compositions .................................. 25

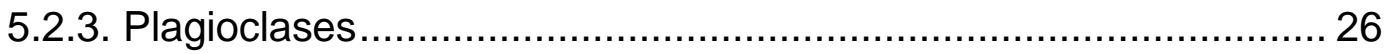

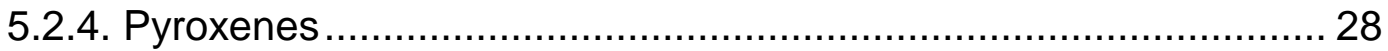

5.2.5. Oxides............................................................................... 30

5.2.6. Temperature and Oxygen Fugacity........................................... 30

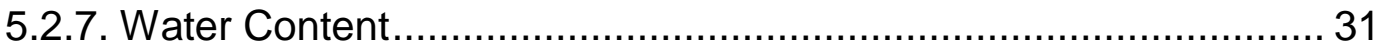

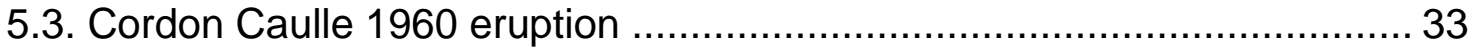

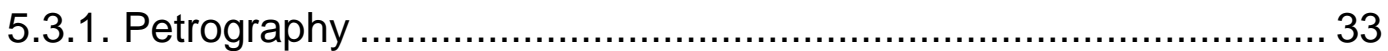

5.3.2. Geochemistry and Minerals compositions ................................. 34

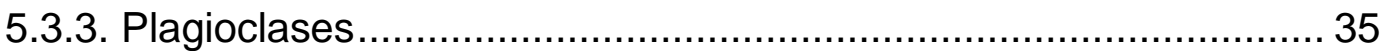

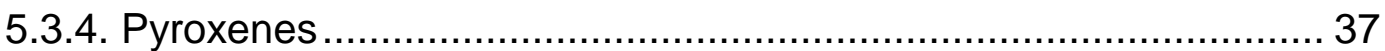

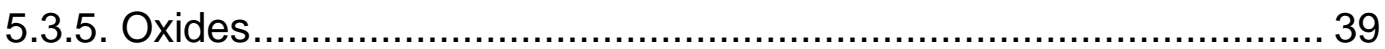

5.3.6. Temperature and Oxygen Fugacity........................................... 39

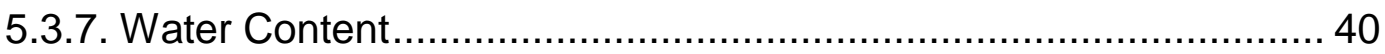

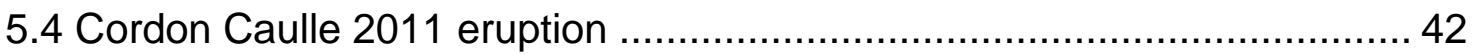

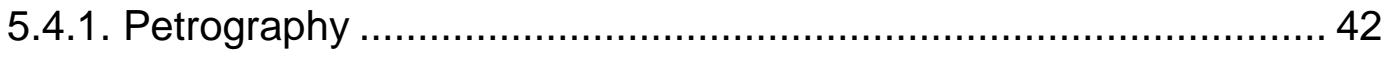

5.4.2. Geochemistry and Minerals compositions ................................. 42

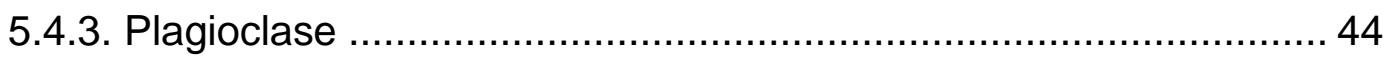

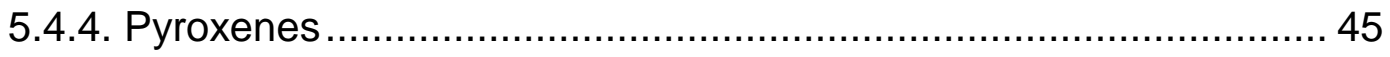

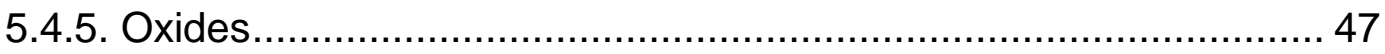

5.4.6. Temperature and Oxygen Fugacity.............................................. 48

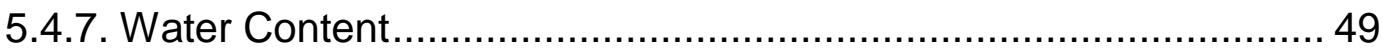

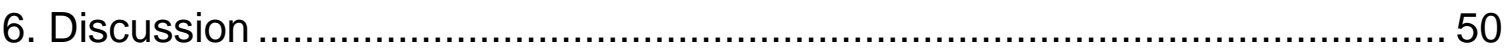

6.1. Temperature and water content comparison across events ................... 50

6.2. Textural analysis in variable changes.................................................. 55

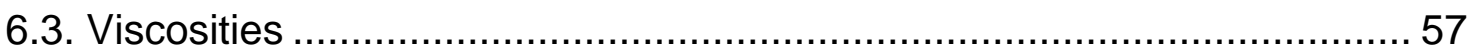

6.4. Equilibrium of Plagioclase phenocrysts ............................................. 59

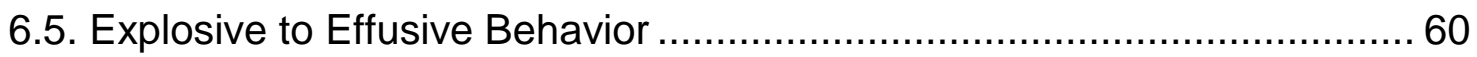

6.6. Magma ascent and possible volcanic triggers ..................................... 61

6.7. Comparing CC historic eruption to other rhyolitic explosive events.......... 62 


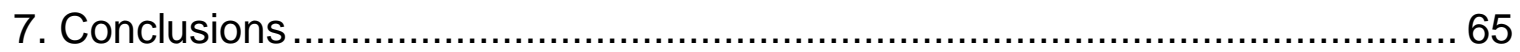

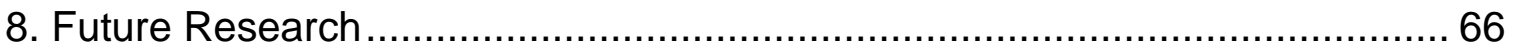

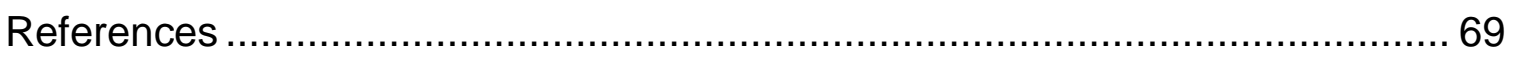

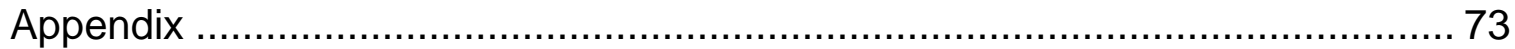




\section{LIST OF TABLES}

TABLE

PAGE

Table 1. Texture group selection for CC historic eruptive events.

Table 2. Major element bulk analysis for 1921 eruptive event, taken from Gerlach et al. (1988).

Table 3. Ghiorso and Evans (2008), thermometry and oxygen fugacity relative to NiNO buffer. Average results per sample for 1960 eruptive event.....

Table 4. Waters and Lange (2015) hygrometry average results per sample for 1921 eruptive event

Table 5. Mayor element bulk analysis for 1960 eruptive event, taken from Gerlach et al. (1988).

Table 6. Ghiorso and Evans (2008), thermometry and oxygen fugacity relative to NiNO buffer. Average results per sample for 1960 eruptive event.....

Table 7. Waters and Lange (2015) hygrometry average results per sample for 1960 eruptive event

Table 8. Geochemical data taken from Waters and Lange (2015) based on Castro et al. (2013) measurements

Table 9. Giohrso and Evans (2008), thermometry and oxygen fugacity relative to NNO buffer. average results per sample for 2011 eruptive event

Table 10. Waters and Lange (2015) hygrometry average measurements per sample for 2011 eruptive event, compared with samples from the present study.....

Table 11. Giordano (2008) viscosity measurements for CC historic eruptive events 


\section{LIST OF FIGURES}

Figure 1. A) Volcanic style classification (Walker. 1973) B) Volcanic Explosive index and tephra volume correlation. Image taken from http://volcanoes.usgs.gov/Products/Pglossary/vei.html .....

Figure 2. PCCVC units and main structures. Map taken from Lara et al. (2006a).8

Figure 3. Geologic map of the Puyehue-Cordón Caulle volcanic complex. The cross section from A-A ' illustrates plausible stratigraphic relations below the complex. 1:50,000 base from Instituto Geographico Militar map 4030-7200.

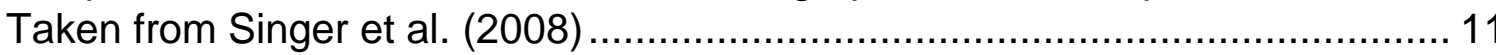

Figure 4. Main flows of 1921 eruptive event. Image from Google Earth ............. 12

Figure 5. Main flow of 1960 eruptive event. Image from Google Earth............... 13

Figure 6. Effusive phase of 2011 eruptive event. Image from Google Earth ...... 14

Figure 7. Bacon and Hirschman test for equilibrium; in black circles are all the measured oxides pairs, the green and blue lines represent the estimated error of the instruments, while the red line represents the equilibrium ......................2 23

Figure 8. Selected samples distribution for 1921 eruptive event ...................... 24

Figure 9. EPMA images for Plagioclase of 1921 eruptive event A) Plagioclase phenocryst sample 42825-pl-R5; B) Microlite sample 42823b-pl-R1m .

C) Cluster plagioclase from sample 42823a.

Figure 10. Ternary classification diagram Ab-An-Or EPMA data for 1921 eruptive event samples. Pink crosses represent phenocrysts and pink circles

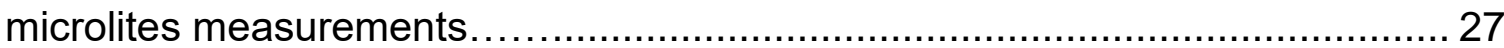

Figure 11. EPMA images of pyroxene crystals for 1921 eruptive event A) Cpx sample42823a-px-R3; B) Opx sample 42823a-px-R3Ot; C) Cpx sample 42828-px-Cot; D) Opx 42828-px-R3. 
Figure 12. Pyroxenes classification ternary diagram for En: Wo: Fa phases.

Pink crosses for EPMA data for pyroxene crystals of 1921 samples

Figure 13. Oxide pairs for 1921 eruptive event. A) inclusion on px crystal pair 72822-Br1m; B) inclusion on pyroxene crystal 42825-R3 C) touching pair 42825-R1

Figure 14. Selected samples distribution for 1960 eruptive event 33

Figure 15. EPMA images for plagioclase grains of 1960 eruptive event. A) Plagioclase phenocryst 132824a-pl-A1. B) Microlite example 132828-pl-E1. C) Cluster plagioclase 132826-PI-A1

Figure 16. Ternary classification diagram Ab-An-Or. EPMA data for 1960 eruptive event samples. In red crosses phenocrysts and red circles microlites measurements.

Figure 17 EPMA images of pyroxene crystals A) Cpx 132824a-px-R1; B) Opx 132824a-R2ot; c) Clxp-132828-px-Got; D) Opx 132828-px-H.

Figure 18. Pyroxene classification ternary diagram for En: Wo: Fa phases. Red crosses for EPMA data for pyroxene crystals of 1921 samples

Figure 19. EPMA images for 1960 eruptive event of: A) touching ilmenite magnetite pair sample 132824x; B) ilmenite and magnetite pair inclusion of Cpx, from sample 128236-EX; C) Adjacent ilmenite Magnetite pair from sample 212825-F.

Figure 20. A) Major-element TAS diagram after Le Bas and Streckeisen (1991).B) and chondrite-normalized REE element chemistry of the 2011 Cordón Caulle rhyolite. Image taken from Castro et al. (2013).

Figure 21. EPMA images for plagioclase grains. A) Plagioclase phenocryst Dtccl11-pl-D. B) Microlite Dtccl11-pl-em. C) Pumice plagioclase crystal Pmh11-pl-1 
Figure 22. Ternary classification diagram Ab-An-Or EPMA data for 2011 eruptive event samples. In green crosses phenocrysts and green circles microlites measurements. In blue squares measurements from Castro et al. (2013)

Figure 23. EPMA images for pyroxene phenocrysts of 2011 eruptive event. A) Cpx Sample Dtccl11-px-F; B) Opx sample Dtccl11-Px-R3.

Figure 24. Pyroxene classification ternary diagram for En: Wo: Fa phases. Green crosses for EPMA data for pyroxene crystals of $2011 \mathrm{dtccl} 11$ sample. Blue Triangles (pumice) and crosses (lava) data from Castro et al. (2013)......47

Figure 25. Oxide pair for 2011 eruptive event. A) adjacent pair dtccl-Ex. B) and C) pumice oxide pair Pmh11-H.

Figure 26. Average measurements per sample of Ghiorso an Evans (2008) temperature vs Water wt\% from Waters and Lange (2015).

Figure 27. Water wt $\%$ content vs An wt $\%$ for different temperature scenarios.

A) Average measurements per sample. B) Highest temperature set constant.

C) Highest Temperature measurement per unit. D) average temperature per unit.

Figure 28. Variable variations across the different texture groups.................... 56

Figure 29. Histogram of pre-eruptive viscosity vs degassed post eruptive lava sample viscosities for all three $\mathrm{CC}$ historic eruptions. 59

Figure 30. Pre-eruptive variable comparison for different volcanic events. 64 


\section{ABBREVIATIONS AND ACRONYMS}

\begin{tabular}{|c|c|}
\hline Ap & Apatite \\
\hline $\mathrm{CC}$ & Cordon Caulle \\
\hline CSVZ & Central Southern Volcanic Zone \\
\hline Cpx & Clinopyroxene \\
\hline DRE & Dense Rock Equivalent \\
\hline EDS & Energy Dispersive X-ray Spectrometry \\
\hline EPMA & Electron probe micro analysis \\
\hline FTIR & Fourier Transform Infrared Spectroscopy \\
\hline III & Ilmenite \\
\hline InSAR & Interferometric Synthetic Aperture Radar \\
\hline LOFZ & Liquine Ofqui Fault Zone \\
\hline $\mathrm{Mg}$ & Magnesium \\
\hline Mgt & Magnetite \\
\hline $\mathrm{Mn}$ & Manganese \\
\hline NNO & Nickel-Nickel oxide \\
\hline NSVZ & North Southern Volcanic Zone \\
\hline Opx & Orthopyroxene \\
\hline $\mathrm{Pl}$ & Plagioclase \\
\hline PCCVC & Puyeuhe Cordon Caulle Volcanic Complex \\
\hline REE & Rare Earth Element \\
\hline SEM & Scanning Electron Microscopy \\
\hline SSVZ & Southern Southern Volcanic Zone \\
\hline SVZ & Southern Volcanic Zone \\
\hline
\end{tabular}


SW

TG

VEI

Wt

$\mathrm{Zr}$
South West

Texture Group

Volcanic Explosive Index

Weight

Zircon 


\section{Introduction}

Volcanos are a window to Earth's interior, and they are a key element to decipher the inner mechanics of the Earth. Volcanos impact the everyday life of human society, for example, they can lead to the formation of major economically profitable ore deposits or provide communities with an energy source such as geothermal energy. They also represent a very important hazard for human communities as they can cause wide range of damage to properties, damage to crop and live-stock fields, air traffic interferences and health problem for citizens. For example, the 2011 Cordon Caulle eruption caused air transport to be cut off completely for a day and it only regained normal service after months, even in faraway places such as New Zealand. In Argentina, it caused the death of 40-60\% of livestock in the Jacobassi district, water supplies were cut off from a major city such as Bariloche that also remained without power for a period of 24 hours. Cleanup of the city was estimated to be around 35 million dollars (Wilson et al., 2013). For these reasons it is of vital importance to understand the mechanisms, evolution and the potential threats that may occur on communities adjacent to volcanic centers. 

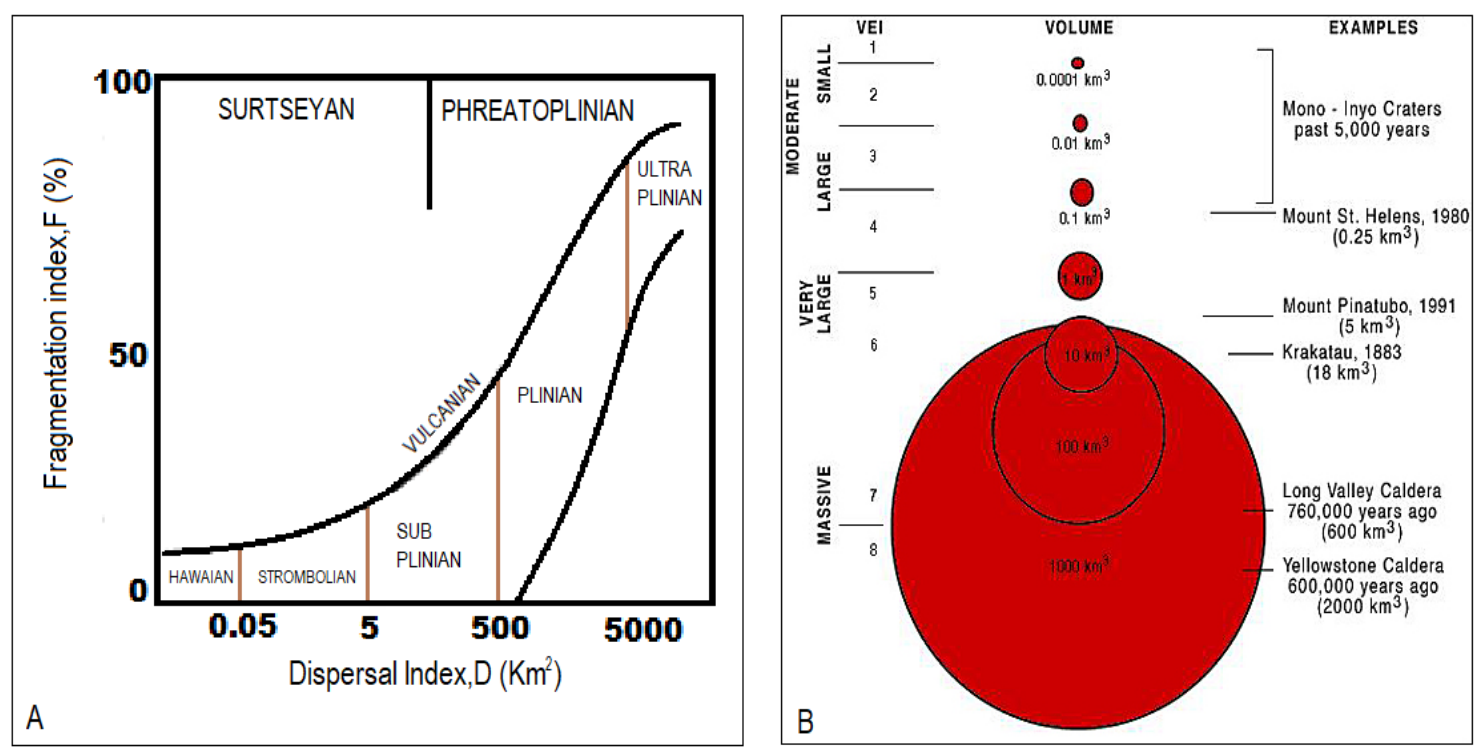

Figure 1. A) Volcanic style classification (Walker. 1973) B) Volcanic Explosive index and tephra volume correlation. image taken from http://volcanoes.usgs.gov/Products/Pglossary/vei.html.

Volcanic eruptions can be classified as either effusive, where the lava is poured on the surface, or explosive, where the main motivating force is the volatile content that expels volcanic materials in a vigorous manner sometimes with great intensity. The explosive eruptions can be classified on the basis of height of the eruptive column, the dispersal of the products and the level of fragmentation of the volcanic material. It is also possible to assign a Volcanic Explosive Index VEI defined by the volume of extruded tephra, which marks the potential threat of a particular center (Fig 1).

Many fields of science study volcanic processes, such as geodesy, geophysics, traditional geology, among others and all of them must be combined to achieve a comprehensive model of volcanic processes. An undisputed approach to study the processes that lead to volcanic eruptions is by the analysis of the 
extruded products from previous events, since they contain the information of how, when, and why the particular events happened. The extruded products are the only source of direct physical evidence that gives clues to the inner workings of the system, therefore a comparison through the historic and geological record of erupted volcanic units can shed light on the evolution and possible future eruptive activities of a particular center. There are some difficulties that arise when trying to understand the mechanisms of volcanic systems because of to the complexity and high extent of interaction among variables. Depending on how the volcanic center evolves, these variables can change, leading to different outcomes. For instance, it is known that a single volcanic center can present different styles between different historic eruptions and even change the eruptive style during the same event. Since volcanos have been studied for decades, some types of explosive activity are well documented and known, such as the top to bottom decompression events, but the explosive nature of the Plinian and complex multipulse hybrid events are still poorly understood, since, the forces that cause them could be influenced by processes that happen in the magmatic chamber (Cassidy et al., 2018 and references therein).

The focus of the present study will be the most recent eruptive events of Cordon Caulle fissure system (CC) that is part of the Puyehue-Cordon Caulle Volcanic Complex (PCCVC) located in southern Chile. The PCCVC is an active system that spanned many geological periods and is still currently active in modern days. The thesis will cover a thorough evaluation of the physical properties inside the magma chamber of the latest three eruptive events of CC corresponding to the 
1921, 1960 and 2011 eruptions, with emphasis on the estimation of the major variables prior to an eruption and narrowing down the mechanisms that lead to a certain type of eruptive style. The variables are inferred from a complete collection of volcanic rocks that are representative of each event, using established mathematical models constructed from the chemical equilibrium of known mineral phases, and evaluating the variations between each event and rock textures. The present study will facilitate future comparisons of volcanic units and eruptive styles through time and will be of vital importance to achieve useful petrologic indicators that can be used for mathematical modeling and increase the database of global systems, as well as contribute to the overall goal of reaching a comprehensive predictive model of volcanic systems for better forecasting.

\section{Geologic Background}

\subsection{The Southern Volcanic Zone (SVZ)}

The SVZ is a segment of the Andes volcanic arc and is over $1400 \mathrm{~km}$ long, located in the southern part of Chile and Argentina from latitudes of 33 to $46^{\circ} \mathrm{S}$. The zone is one of the five major segments of the long and active Andes mountain range volcanic arc. The SVZ is distinguished from other segments on the basis of several morpho-tectonic features where the presence of active volcanism is the determining tool to differentiate each segment. The SVZ can be further divided into

4 sub-segments: The Northern $33-34.5^{\circ} \mathrm{S}$; Transitional $34.5-37^{\circ} \mathrm{S}$; Central $37-$ $41.5^{\circ} \mathrm{S}$ and Southern $41.5-46^{\circ} \mathrm{S}$ SVZs (Stern, 2004 and references therein). It has over 60 active volcanic systems and the rock compositions are mostly basaltic to 
andesitic in nature (Lopez-Escobar et al., 1981; Hickey et al., 1986; Tormey et al., 1991). Even though the majority of the rocks are basaltic there is an appreciable number of highly differentiated volcanic centers, mostly located in the CSVZ and NSVZ but not exclusive to these areas. The crustal thickness of the SVZ goes from $50 \mathrm{~km}$ in the northern section to approximately $30 \mathrm{~km}$ in the southern part. The rhyolitic centers of the NSVZ have evidence of continental crust assimilation while the thin crust of the CSVZ and SSVZ suggests that the crustal assimilation does not play a big role in the development of the dacitic to rhyolitic magmas, but instead is the result of crystal fractionation from the liquid phase (Gerlach, 1988) or the assimilation of young basaltic rich crust geochemically similar to its products (McMillian et al., 1989). Regardless of their origin, the most evolved andesitic, dacitic or rhyolitic volcanic centers can be highly explosive. For example, the Villarrica volcano showed evidence of explosive pyroclastic flows at ages of approximately 14,000 years ago (Clavero and Moreno, 2004) and is still active to this day with its latest eruption in 2015. The Calbuco volcano is one of the most active and explosive centers with over ten eruptions in recent history since 1837, and Puyehue-Cordon Caulle, which is the object of the current study and will be described further, among others.

\subsection{Structural controls}

The distribution of the volcanic centers in the SVZ is complex, but it results from two major factors determined by : 1) if they respond to the actual compressional or dextral transpressional tectonic conditions of present times 
(Cembrano et al., 1996, Herve, 1994), or 2) if they respond to the basement conditions, crustal thickness and the presence of the NNE trending Liquine Ofqui fault (LOFZ), which is a $1000 \mathrm{~km}$ long strike-slip and vertical displacement zone that goes through the NSVZ and CSVZ (Lavenu and Cembrano, 1999, Lopez Escobar et al., 1995). The interaction between these factors results in a complex plumbing system having major impact on the volcanic eruption style. If the faults cut through the lithosphere, rapid magma ascent is favored, resulting in more basic volcanic centers with monogenetic eruptions, as is the case with the basaltic monogenetic cones lined up with the LOFZ. (Cembrano and Lara, 2009). On the other hand, more complex interconnected fault systems derived of second-order pathways from the LOFZ and a compressional environment favor longer residence times in magmatic chambers, resulting in more differentiated dacitic/rhyolitic products (Cembrano and Lara, 2009) that can lead to more explosive events. Therefore, the structural control of the volcanic arc plays a major role on the type of volcanic eruption.

\subsection{Puyehue Cordon Caulle Volcanic Complex (PCCVC)}

The PCCVC is one of the over 50 active volcanos of the SVZ, and it is situated at the summit of a plateau, where the basement is comprised of the granitoids from the 10-6.5 million years old north Patagonian batholith (Campos et al., 1998). 
The PCCVC includes the latest Pleistocene to Holocene "Puyehue" stratovolcano, which is built of approximately $18 \mathrm{~km}^{3}$ of basaltic to rhyolitic lava and tephra deposits and reaches an elevation of $2236 \mathrm{~m}$ with a $2.5-\mathrm{km}$-diameter, 280-m deep caldera-like crater at its summit. It also includes the Pleistocene to Holocene CC, comprised of dacitic to rhyolitic units that extend $20 \mathrm{~km}$ along a fissure zone that trends northwest, starting from the stratovolcano to the ancient caldera of Cordillera Nevada. The CC fissure is emplaced on top of the Ichupe River Fault that is an oblique branch of the LOFZ that responds to the late Cenozoic transpressive regime (Fig. 2; Gerlach, 1988; Lara et al., 2006a) 


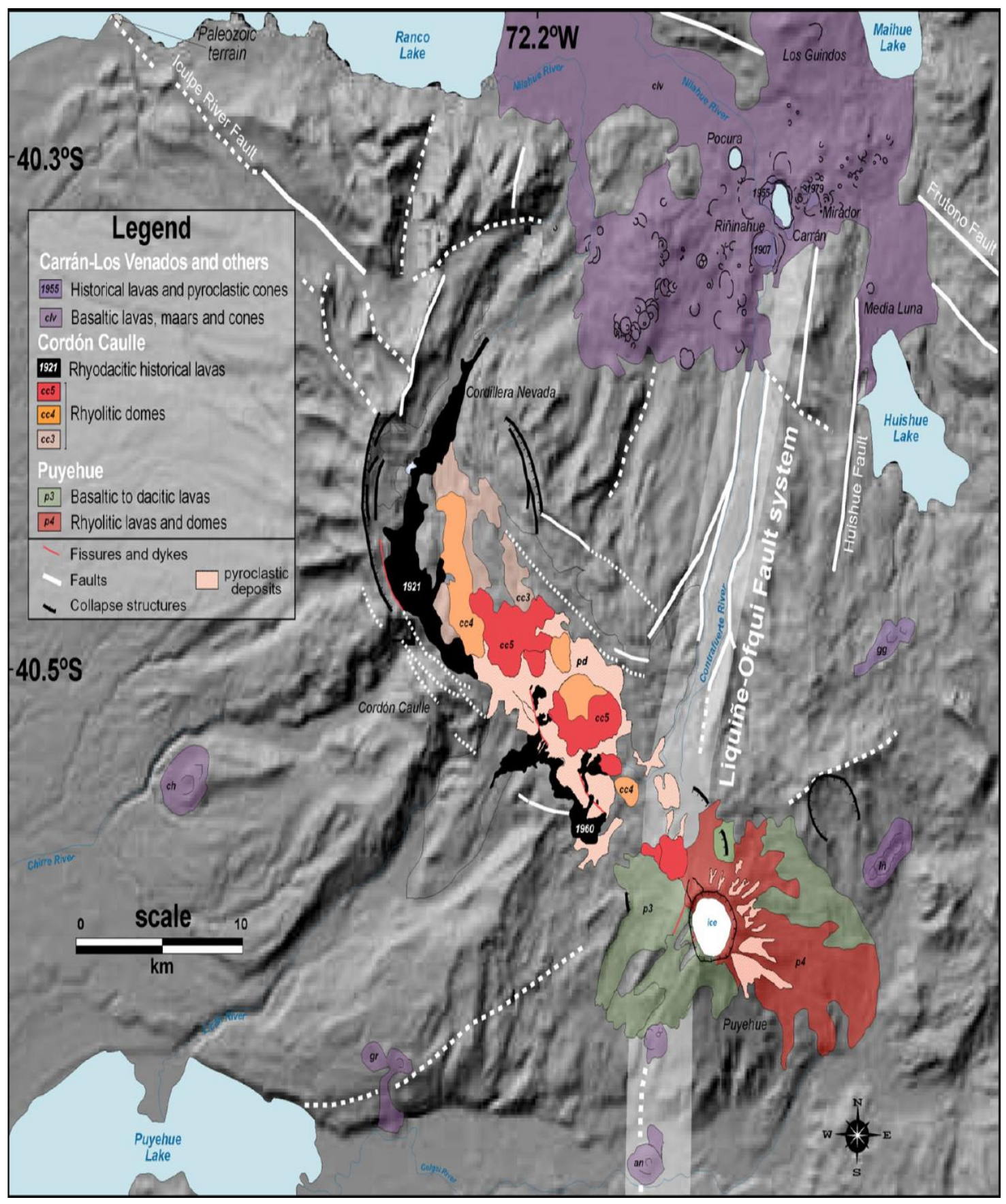

Figure 2. PCCVC units and main structures. Map taken from Lara et al. (2006a). 


\subsection{Volcanic Stratigraphy}

\subsubsection{Puyehue Volcano}

Gerlach (1988), expanding the work of Moreno-Roa (1977), noted that the main strato-volcano was built on top of an ancient eroded edifice of similar age to Cordillera Nevada, denominated PI, which is composed of tephra and is intruded by massive dikes of basaltic, andesitic and dacitic compositions. Following this unit the main building stage of the edifice was divided into three units PII, PIII and PIV, with PII (early stage) representing almost $70 \%$ of the edifice composed mostly of basaltic flows. The activity of the volcano got more explosive over time with unit PIII producing thick tephra units and pyroclastic activity near the crater with presence of rhyolitic to dacitic bombs. PIV corresponds to dacites and andesites with some pyroclastic activities. More modern studies like Lara et al. (2006b) and later Singer et al. (2008) further expand the divisions resulting in eight distinct mappable units (Fig 3), defined by isotopic dating, field research, and geochemical evidence.

\subsubsection{Cordon Caulle (CC)}

Cordon Caulle is the fissure system that hosts the most modern eruptions of PCCVC. Lara (2006b) has separated five units defined by the tectonic settings, which are distributed between a pre-graben stage of shield volcanism or an intra graben stage. The first 2 units, the CCI and CCII, first noted by Moreno-Roa (1977), belong to the older shield stage pre-graben, mainly dominated by basaltic and 
andesitic rocks, however the $\mathrm{CCl}$ also has some rhyolites with some of the highest silica contents of the PCCVC. The intra graben stage is divided into units CCIII, CIV and CCV, dominated by dacitic flows and pyroclastic deposits, and the most recent historic events of 1921 and 1960 characterized by rhyolites. The units were further divided by Singer et al. (2008) into three groups based on chronostratigraphic relations which are: 1 ) early CC erosional remnants, ages of $>173-73 \mathrm{Ka}$, grouping $\mathrm{CCl}, \mathrm{CCll}$ (previously mentioned) and the two new separated units Cig and Cas, corresponding to the sills and dikes; 2) the younger lavas and tephra from 54ka until modern times, with unit Cca, the oldest unit of the group consisting of andesitic lavas; CCIII mostly dacitic to rhyolitic flows with some pyroclastic activity; CCIV corresponding to rhyolitic domes and coulees with pumice cones and CCV, rhyolitic domes with evidence of explosive events; 3) the historic events of 1921 and 1960 (Fig. 3) with the newly added 2011 eruptive event. 


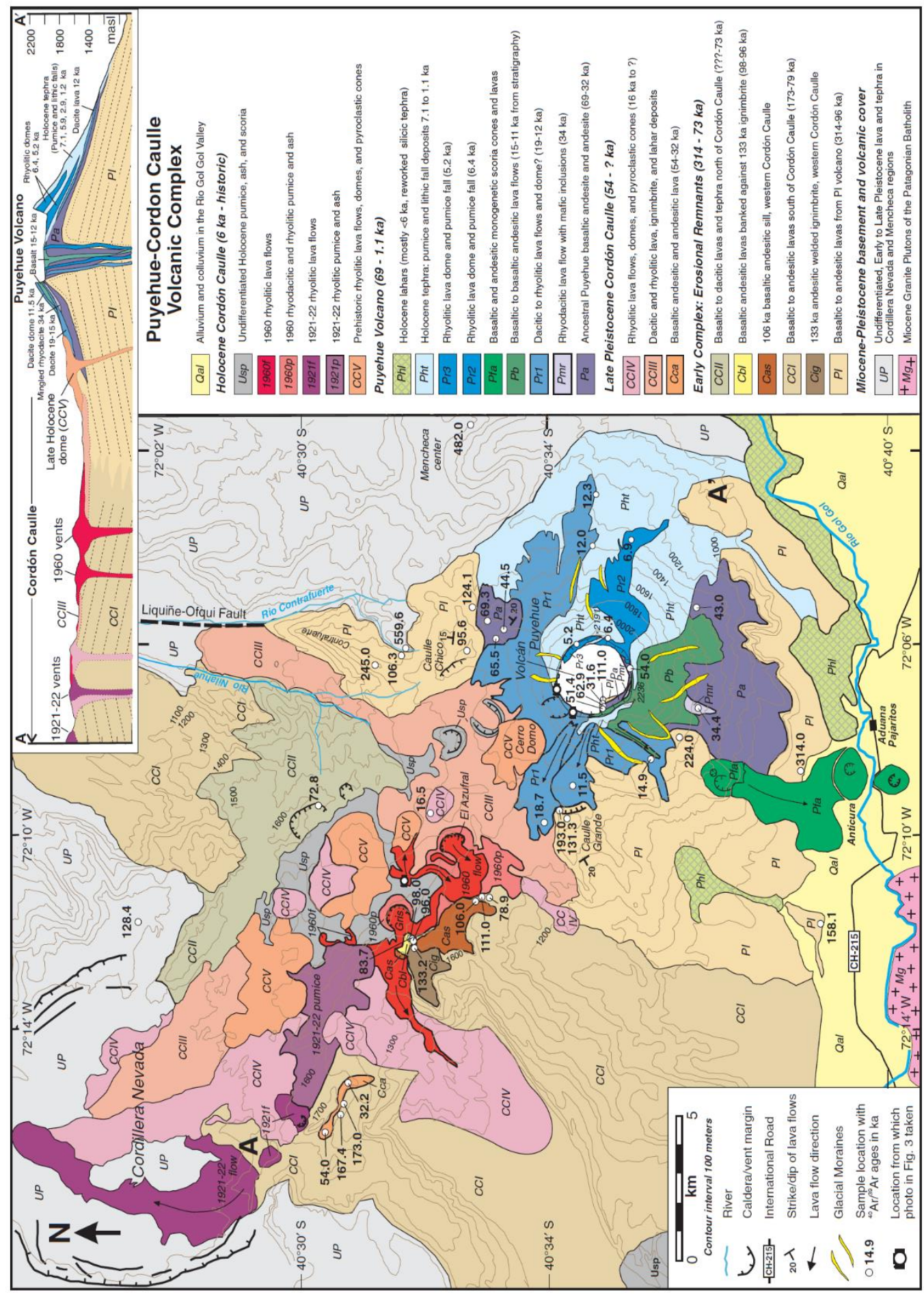

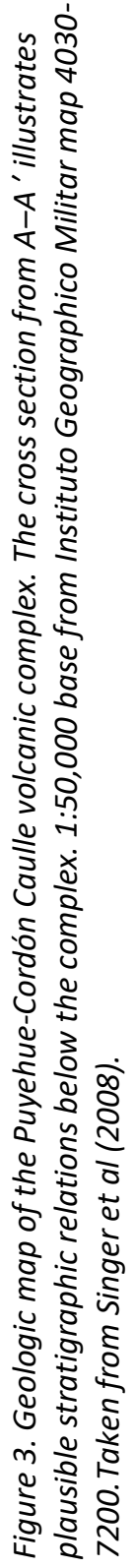




\subsection{Historic eruptive events}

\subsubsection{1 eruptive event}

The 1921 eruptive event has little information as not many journalistic reports remain, but according to Lara (2006b and references there in), during December of 1921 until mid-1922, Cordon Caulle's fissure system started an eruptive stage that produced a $6.2 \mathrm{~km}$ high sub Plinian column alternating with explosive and seismic activity, followed by a later second stage of dacitic effusive lava flows with an average $\mathrm{SiO}_{2}$ content of $69.6 \mathrm{wt} \%$ (Lara et al., 2004, 2006b) that drained from a set of $8 \mathrm{~km}$ ring faults inside Cordillera Nevada caldera (Fig.4).

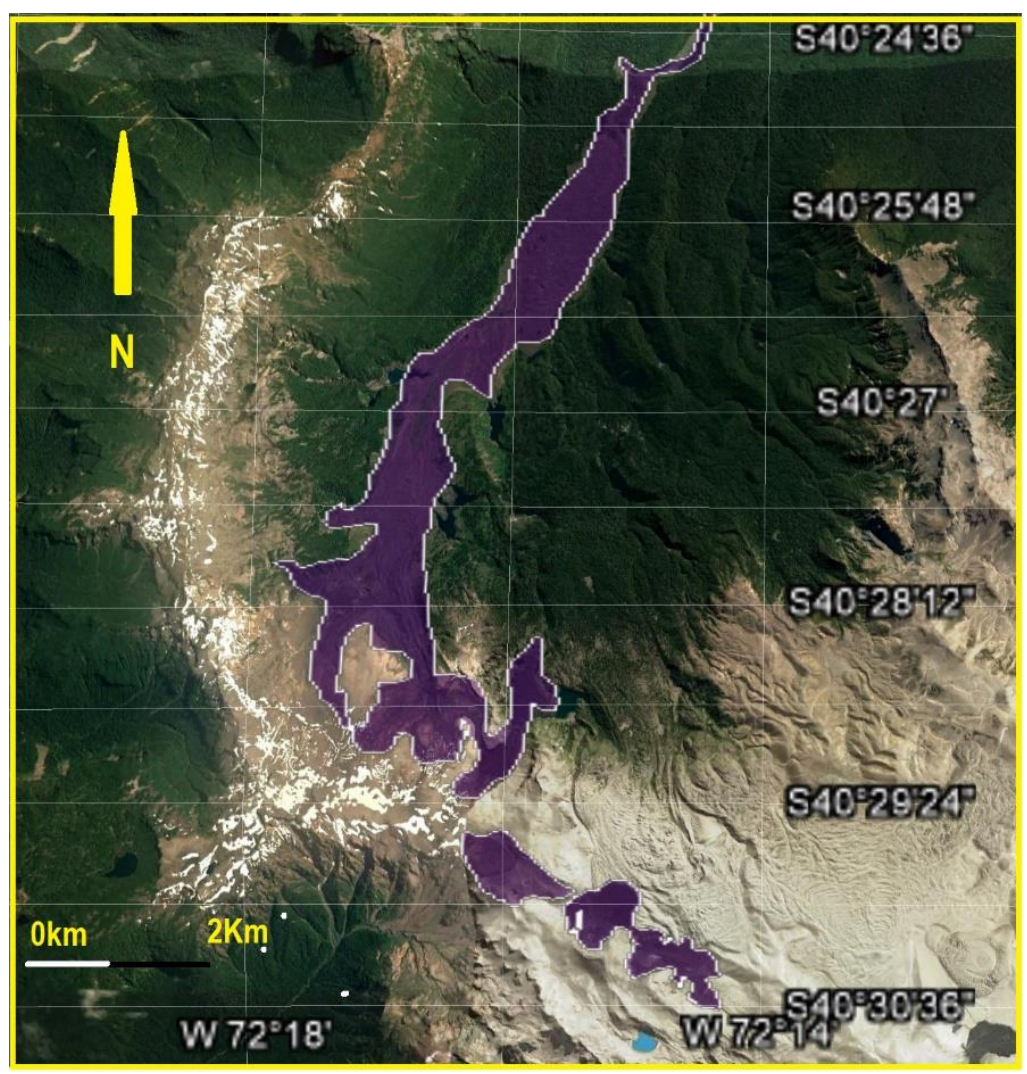

Figure 4. Main flows of 1921 eruptive event. Image from google earth 


\subsubsection{0 eruptive event}

On the 22nd of May in 1960, the region of Valdivia, Chile suffered the most powerful earthquake ever recorded on Earth, with a 9.5 magnitude on the Richter scale. This damaging event may have triggered the CC 1960 eruption, which occurred 38 hours after the earthquake on 24th of May. The eruptive cycle started with an explosive sub-Plinian phase and the formation of an $8 \mathrm{~km}$ high eruptive column. The southern part of the CC fissure system has sited 21 identifiable vents along a 5.5km long zone (Fig. 5), which emitted pyroclastic ejecta and lava flows of rhyodacitic composition $\left(68.9-70.01 \% \mathrm{SiO}_{2}\right)$ with $\mathrm{DRE}$ total volume of $0.25 \mathrm{~km}^{3}$ (Lara et al., 2004, Lara et al., 2006, Singer et al., 2008) (Figure 5).

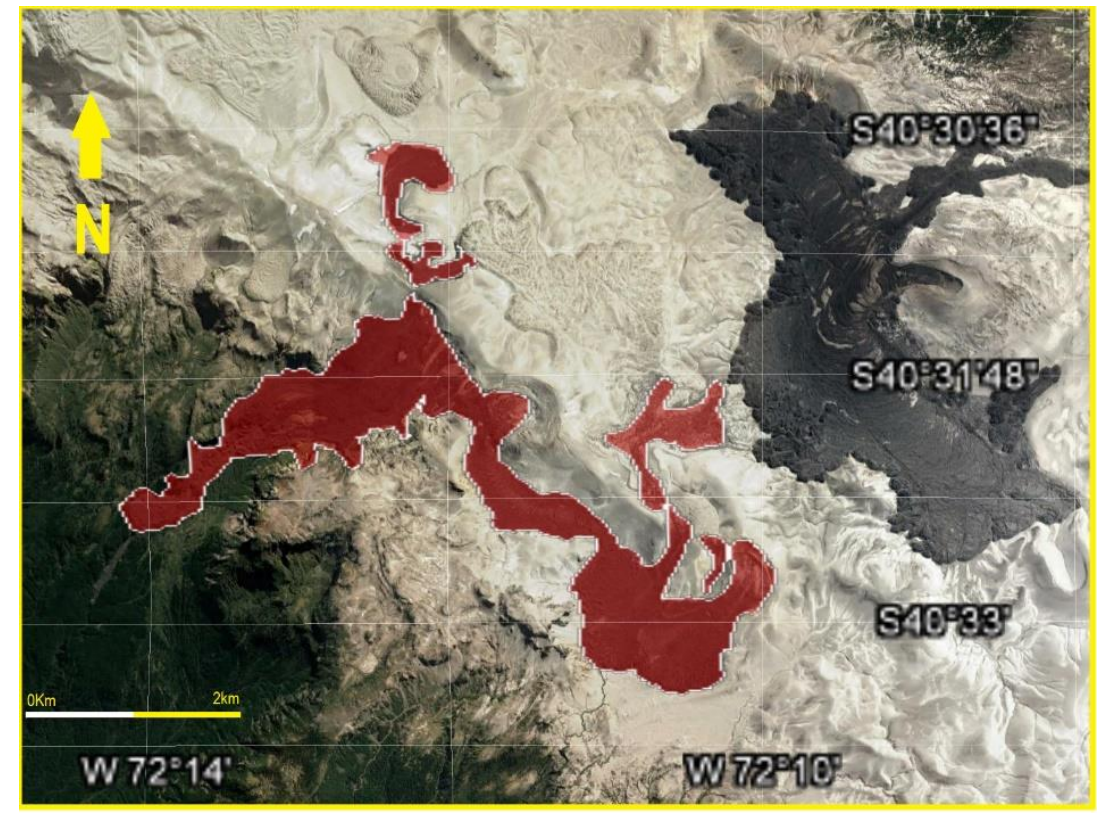

Figure 5. Main flow of 1960 eruptive event. Image from google earth 


\subsubsection{1 event}

The latest eruptive event started on June $4^{\text {th }}$ of 2011 . This event was classified as a Plinian to sub Plinian event with a VEI $>$ or $=$ to 5 , that developed an eruptive column of approximately $15 \mathrm{~km}$ high. It was a hybrid eruptive event with transitions between effusive (Fig 6), and explosive activity. By January 2012, the activity declined from sustained Plinian to intermittent sub-Plinian fountaining, to mixed gas- and ash-jetting punctuated by Vulcanian blasts. One of the most important aspects of this event is the synchronous effusive activity from the same vents that continue to expel sub Plinian ash columns (Castro et al., 2013, Silva Parejas et al., 2012) making this event particularly useful for understanding the transition between explosive and effusive activity.

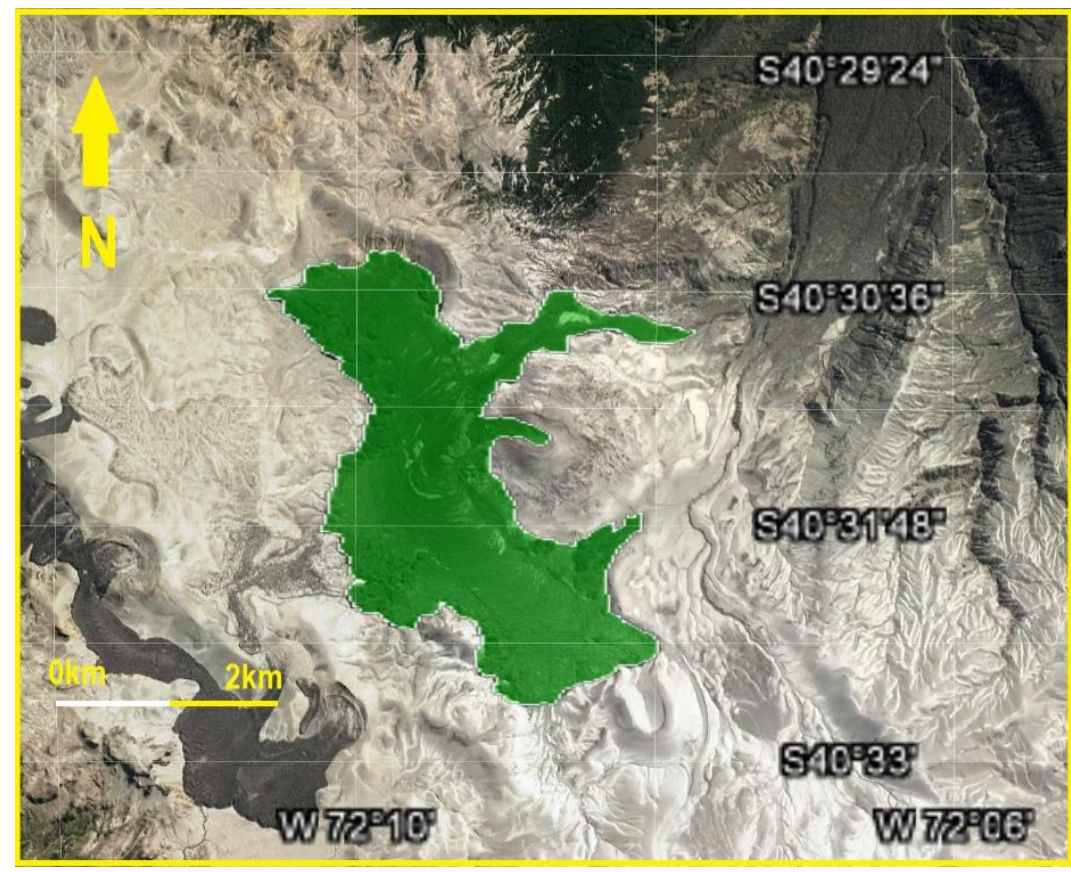

Figure 6. Effusive phase of 2011 eruptive event. Image from google earth. 


\subsection{Sample acquisition}

The samples for CC unit V (after Lara, 2006b), the 1921 and 1960 effusive phase for variable analysis in the present study, were acquired from a collection available from a sampling campaign to PCCVC region by Gerlach and HickeyVargas in 1982.

To complement and complete the historic events, two samples were selected for the 2011 eruptive event, one pumice collected by Hickey-Vargas in 2013 and a 2011 lava rock collected by Daniel Tormey in 2012.

\section{Background on methods used to determine pre-eruptive variables}

\subsection{Temperature}

Geothermometers are essential tools that can reveal necessary information to fully understand the driving forces of volcanic systems. These models depend on the equilibrium of chemical reaction(s) between two or more phases (e.g., minerals, melt). Because the extent of chemical equilibrium is determined by kinetic factors, such as solid-state diffusion, reactions become inhibited below a threshold (or "closure") temperature that in volcanic rocks is often considered to be the eruption temperature (Blundy and Cashman, 2008). Thermometers and barometers have been proven to be used to calculate temperatures and pressures to a precision of $\pm 30^{\circ} \mathrm{C}$ and $\pm 1.5 \mathrm{kbar}$, respectively, for individual mineral- melt or mineral-mineral pairs (Putirka, 2008). One of the most widely used is the Ghiorso and Evans (2008) thermometer that works under the assumption of equilibrium of 
magnetite and ilmenite mineral phases and the interaction reactions between them. Fe-Ti oxides have been shown experimentally to re-equilibrate quickly in response to changes in temperature and/or $\mathrm{fO}_{2}$, but not so much for pressure (Hammond and Taylor., 1982; Venezky and Rutherford., 1999), making the model very reliable for sub-surface processes.

The Ghiorso and Evans (2008) thermometer was used on mineral samples for the 2011 Cordon Caulle eruption in Castro et al. (2013) obtaining average temperature of $890^{\circ} \mathrm{C}$. Further analysis of Castro's data will be used in the present study for comparison to the new measurements.

\subsection{Water Content}

The dissolved water content in the melt is an important variable because, in context of arc volcanos, it is the mayor volatile phase of the magma. The water content plays a major role in shaping the physical characteristics of the melts having major influence on the viscosity, fusion points, and even in chemical stability of the mineral phases. It is hard to measure the water content of a magmatic body since after the extrusion to the surface, post-volcanic processes change the quantity in the melt, for example by degassing or even by rehydrating of rocks after extrusion. For the 2011 eruptive event, Castro et al. (2013) measured volatile content through analysis of melt inclusions on plagioclase grains with results of 0.74 to $2.4 \mathrm{wt} \%$ but this value is lower than the 2.5 to $4 \mathrm{wt} \%$ estimated in his phase equilibrium experiments meaning that the inclusions volatile content could have leaked (Castro et al., 2013). 
The water content component obtained through direct measurements of extruded products do not represent the in-chamber conditions. However, just as temperature, water acts as a phase in chemical stability of the mineral components therefore if equilibrium of minerals can be achieved, the water content can be estimated through phase analysis calculations, like the hygrometer model proposed by Lange et al. (2009), and later recalibrated by Waters and Lange (2015), for rhyolitic liquids. It is based on the plagioclase-liquid exchange reaction between the albite $\left(\mathrm{NaAlSi}_{3} \mathrm{O}_{8}\right)$ and anorthite $\left(\mathrm{CaAl}_{2} \mathrm{Si}_{2} \mathrm{O}_{8}\right)$ endmembers. The model takes into account calorimetric and volumetric standard-state data along with phase-equilibrium experiments to appreciate how temperature, pressure, and liquid composition each contribute to the partitioning of albite. The model is sensitive to dissolved water concentrations and temperature but not so much for pressure; if the temperature is known a calculated water weight percentage content can be inferred.

\subsection{Pressure}

The pressure conditions in the magma chamber can determine how an eruption takes place, however it is a difficult variable to constrain as a result of the role of different volatile species and the uncertainty in the methods used to acquire the depths of the magmatic storage. To obtain the pressure value, Castro et al. (2013) made phase relation experiments and was able to accurately constrain a pressure range of approximately $50-100 \mathrm{MPa}$ which would situate the magmatic body for the 2011 eruptive event at a shallow depth of $2-5 \mathrm{~km}$. Another study used Interferometric Synthetic Aperture Radar (InSAR) have proposed an over $8 \mathrm{~km}$ 
long magmatic body at depths of 4 to $9 \mathrm{~km}$ depth that may be the main source for all three eruptive events (Jay et al., 2014). Therefore, the pressure limits of Castro can be applicable for both the 1921 and 1960 events.

Even though there is a wide range of probable pressures; the possible values do not bring changes to the overall results, since in the proposed thermometer and hygrometer, the pressure is almost neglectable due to the fact that the volume change in the exchange reactions is minimal compared to the enthalpy variations in said exchange reactions (Waters and Lange., 2015; Lange., 2009; Blundy and Cashman., 2008). Just to be sure in the present study, an average pressure of $100 \mathrm{Mp}$ was used on the models but was tested for up to $500 \mathrm{Mp}$ without experiencing significant changes in the results.

\section{Analytical Methods}

\subsection{Sample selection}

A selection of samples was carried out choosing the most significant textures present in each of the three selected units of Cordon Caulle, corresponding to the most recent historic eruptions of years 1921, 1960 and 2011.The reason for the selected textures is that each style represents a different stage of the eruptive events or volcanic flow zone, where volatile content played a major role in its development, therefore each temperature and water content calculated can be compared within and across each eruptive event. To facilitate the comparison between events, five different texture groups can be separated, where the main difference between each texture group is defined by the glass 
percentage in the groundmass and the vesicle morphology and volume (Table 1). It's important to clarify that even thou the texture groups are distinct from one another there is a transition with a possible evolution through the groups starting with a halophilic rock with lacking bubbles (TG1) than eventually the volatile phase is separated from the glass forming a large volume of bubbles that are isolated from each other (TG2), eventually the bubbles start coalescing with each other forming bands (TG3), and finally when the magma is free of volatile species having an obsidian phase as the outcome (TG4). However, TG4 and TG1 could be interchangeable to clarify this point further analysis is required. Refer to the image section of the appendix for photos of the textural group samples.

\begin{tabular}{|c|c|c|}
\hline Texture Group & Description & Samples represented \\
\hline TG1 & $\begin{array}{l}\text { Hyalopilitic texture groundmass with no } \\
\text { vesicles }\end{array}$ & $\begin{array}{l}-42825(1921) \\
-\quad 132824 a(1960)\end{array}$ \\
\hline TG2 & $\begin{array}{l}\text { Hyalopilitic texture with small size } \\
\text { vesicles up to } 40 \% \text { volume }\end{array}$ & $\begin{array}{l}-42823 a(1921) \\
-\quad 132826(1960)\end{array}$ \\
\hline TG3 & $\begin{array}{l}\text { Hyalopilitic texture with irregular shape } \\
\text { interconnected vesicles in bands varying } \\
\text { total volume }\end{array}$ & $\begin{array}{ccc}- & 42828 & (1921) \\
- & 212825 & (1960) \\
- & 132828 & (1960) \\
& & \\
- & \text { Dtccl11 } & (2011)\end{array}$ \\
\hline TG4 & $\begin{array}{l}\text { Holohyaline obsidian sample with } \\
\text { a very low percentage of vesicles } \\
\text { or absent. }\end{array}$ & $\begin{array}{l}-42823 b \quad(1921) \\
-\quad 72822 \quad(1921) \\
-\quad 212823 b \quad(1960)\end{array}$ \\
\hline
\end{tabular}




\begin{tabular}{|l|l|l|}
\hline TG5 & Pumice & - Pmh11 (2011) \\
\hline
\end{tabular}

Samples for Cordon Caulle Unit IV were also considered, however the geochemical composition of the oxides did not meet the requirements for the use of the proposed thermometer, since the ilmenite phase is absent completely from the rock samples, therefore the samples were left out of the present study, but will be considered for future research.

Five samples were chosen from the 1921 and 1960 eruptive event and two from 2011, representing different flows geographically distinct from one another. The selected samples were cut with a rock saw and sent to National Petrographic Laboratories to produce the polished cross sections of 30 um thickness. There is one sample of pumice that belongs to the 2011 event that was impregnated with epoxy and polished at FIU for a proper EPMA visualization.

The polished sections were analyzed under a petrographic polarized light microscope with 4 to $30 \times$ magnifying lens with the purpose of selecting mineral pairs that reflect chemical equilibrium measured by the petrographic analysis of textures.

\subsection{SEM}

Once the oxide grains were selected, the samples were analyzed under SEM low vacuum with the purpose of separating only useful mineral pairs, consisting of ilmenite and magnetite grains that fulfill the condition needed for 
proper temperature measurements for the selected model. The EDS method was used for identification of the mineral species that would later be analyzed for quantitative results on the EPMA.

\subsection{EPMA}

The samples were carbon coated and the selected oxides, pyroxenes and plagioclase mineral phases were analyzed with a JEOL 8900r EPMA with EDS instrument. The spot size used is approximately 1.5 microns in diameter and the acceleration voltage is $15 \mathrm{kv}$ and sample current set to 20 Nano amps. The system is adjusted to a specific optical position and is in optical focus for each analysis, then compared to the collected spectra from known standards.

\subsection{Thermometry}

The Ghiorso and Evans (2008) thermometer was used to acquire the preeruptive conditions of temperature. To obtain the most accurate results, the oxide mineral pair selection follows the criteria cited in Blundy and Cashman (2008), selecting crystal pairs of ilmenite and magnetite that are either touching, in inclusions of a particular mineral phase or very close to each other in a homogeneous surrounding groundmass; these conditions guarantee the chemical exchange between the elements. As a second method to confirm the validity of the pairs, all of them were tested for equilibrium through the Bacon and Hirschman (1988) equilibrium test, defined by $\mathrm{Mg} / \mathrm{Mn}$ ratios on the exchange reaction. See appendix for expanded discussion. 


\subsection{Hygrometry}

Waters and Lange (2015) calibrated hygrometer is used to acquire the water wt\% for two plagioclase populations: 1) phenocrysts, which are in equilibrium with the liquids and possibly represent the conditions in the magma chamber, and 2) microlites in the groundmass, possibly representing syn-eruptive stage. The difference between both populations can be used to assess if the rock underwent decompression crystallization or crystallized under a loss of volatile content process. The water content is also compared for all the different texture groups to evaluate if the volatile content in the chamber reflects the development of posteruptive vesicles. See appendix for expanded discussion

\subsection{Viscosity}

The model selected for the present study is Giordano (2008), which gives us the opportunity to calculate viscosity values of in-chamber magma based on the bulk composition, water measurements and phenocryst content. The obtained value is an estimation and must be treated as such since there is also the factor of bubbles that can either increase of decrease viscosity of magmas (Cassidy et al., 2018; Giordano, 2008). See appendix for expanded discussion

\subsection{Plots}

The graphical interpretations are made on plots from either Excel spreadsheets or GCDkit software (Janoušek et al., 2006) 


\section{Results}

\subsection{IImenite-Magnetite pairs}

The present study, 49 ilmenite-magnetite pairs were chosen and tested for equilibrium (Fig. 7). The mineral pairs that did not pass the test, for being outside the envelope lines of error, were discarded. The pairs that are either too far away from each other, or have evidence of textural disequilibrium, were also removed from the pre-eruptive variable calculation.

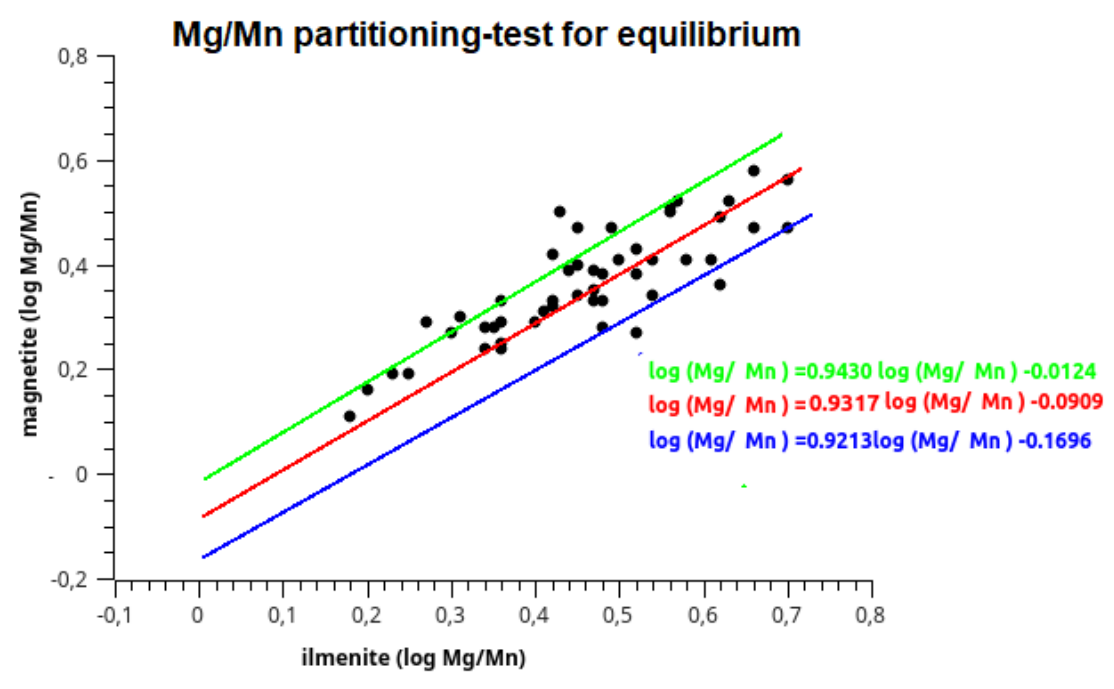

Figure 7. Bacon and Hirschman test for equilibrium in black circles are all the measured oxides pairs, the green and blue lines represent the estimated error of the instruments, while the red line represents the equilibrium.

In addition, there are 2 mineral pairs representing inclusions in multi-minerallic clusters (table 26,27 and 28 of the appendix), that pass the equilibrium test. When performing the calculation for the thermometer, these result in a higher than average temperature (Table 14 of the appendix), therefore were removed 
from the calculations of the pre eruptive variables. However, the presence of these high temperature results could indicate a temperature zonation in chamber and possible the inclusion of high temperature material from deeper sources.

\subsection{Cordon Caulle 1921 eruption}

The five samples selected, which represent the 4 main texture groups of the present study, belong to three of the main flows of the northwestern part of CC from an $8 \mathrm{~km}$ long ring fault system inside Cordillera Nevada, that acted as vents for this event (Fig.8).

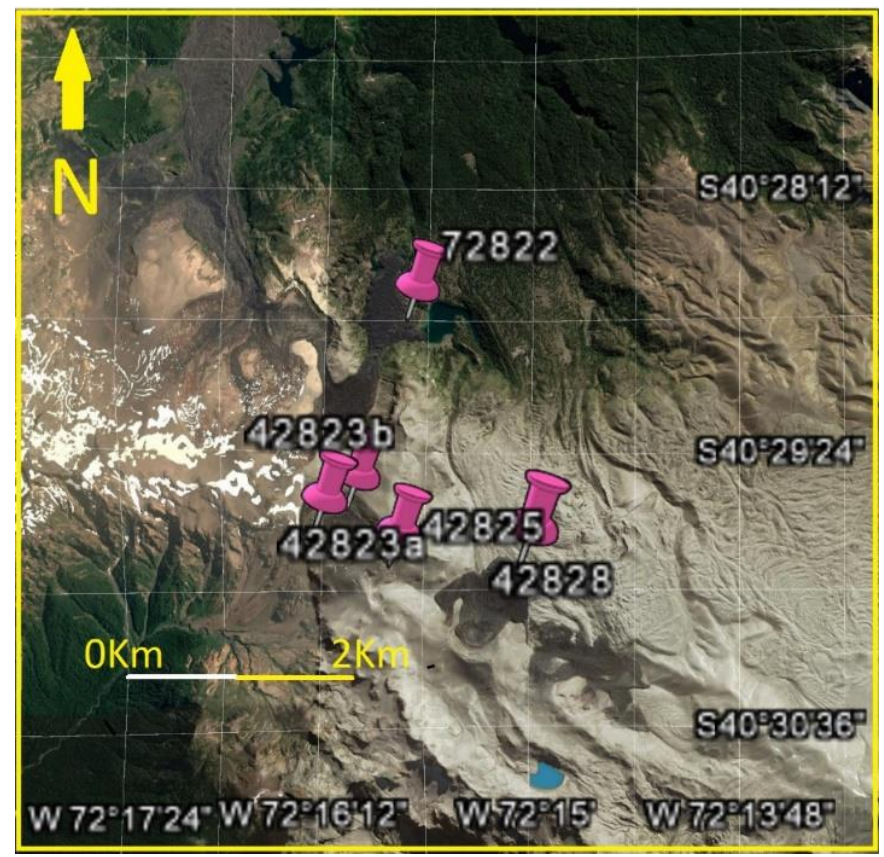

Figure 8. Selected samples distribution for 1921 eruptive event. 


\subsubsection{Petrography}

The selected rock samples have, in general, vitrophyric textures with low percentage of phenocrysts, and holohyaline to hyalopilitic ground mass textures, with flow bands and occasionally trachytic textures for microlites. The rock sample with highest phenocryst volume is the sample representing TG4 with approximately $10 \%$, while the rest of the samples have 5 to $7 \%$. All phenocrysts components are equal in all rock samples with mineral phases of $\mathrm{PI}, \mathrm{Cpx}$, Opx, Mgt, III $\pm \mathrm{Ap}$, Zr. Plagioclase is always the most abundant phase with a ratio of 10:1 over the mafic minerals, while the different samples have varying ratios of Cpx to Opx. The size of the crystal grains is variable and mostly due to the presence of mineral clusters, which are represented in almost all samples and are composed of all the same mineral phases as the phenocrysts. The size in the clusters can be up to $5 \mathrm{~mm}$ for plagioclase, while the average size for the plagioclase phenocrysts is $0.75-0.5 \mathrm{~mm}$; the same stands for all the mineral

components having increased size crystals in clusters (see Table 26 of the appendix).

\subsubsection{Geochemistry and Mineral Compositions}

The bulk magma composition for the 1921 eruptive event (Table 2; Gerlach et al., 1988) plots in the dacite category (Fig. 20). Overall the compositions are very homogeneous with an average $\mathrm{SiO}_{2}$ content of $68.88 \%$ and an average sum of alkali components of $7.22 \%$. The volatile content was also measured and has $0.18 w t \%$ average values of total water content. 


\begin{tabular}{|c|c|c|c|c|}
\hline Event & \multicolumn{4}{|c|}{1921} \\
\hline Sample & 42821 & 72822 & $42823 b$ & 42826 \\
\hline $\mathrm{SiO}_{2}$ & 68.55 & 68.96 & 69.3 & 68.71 \\
\hline $\mathrm{TiO}_{2}$ & 0.79 & 0.79 & 0.77 & 0.73 \\
\hline $\mathrm{Al}_{2} \mathrm{O}_{3}$ & 14.32 & 14.34 & 14.48 & 14.26 \\
\hline $\mathrm{MnO}$ & 0.12 & 0.11 & 0.13 & 0.14 \\
\hline $\mathrm{MgO}$ & 0.62 & 0.6 & 0.57 & 0.7 \\
\hline $\mathrm{FeO}$ & 4.9 & 4.92 & 4.8 & 4.69 \\
\hline $\mathrm{K}_{2} \mathrm{O}$ & 2.59 & 2.62 & 2.62 & 2.61 \\
\hline $\mathrm{Na} 2 \mathrm{O}$ & 4.95 & 5.15 & 5.06 & 5.26 \\
\hline $\mathrm{CaO}$ & 2.52 & 2.55 & 2.43 & 2.4 \\
\hline $\mathrm{P}_{2} \mathrm{O}_{5}$ & 0.17 & 0.17 & 0.15 & 0.16 \\
\hline $\mathrm{H}_{2} \mathrm{O}$ & 0.14 & 0.13 & 0.15 & 0.22 \\
\hline Total & 99.68 & 100.36 & 100.53 & 99.88 \\
\hline
\end{tabular}

\subsubsection{Plagioclases}

The plagioclase crystals are the dominant phase among all the phenocrysts in all rock samples; they are usually present as euhedral prismatic grains with polysynthetic twinning or as large zoned prismatic crystals as part of mineral
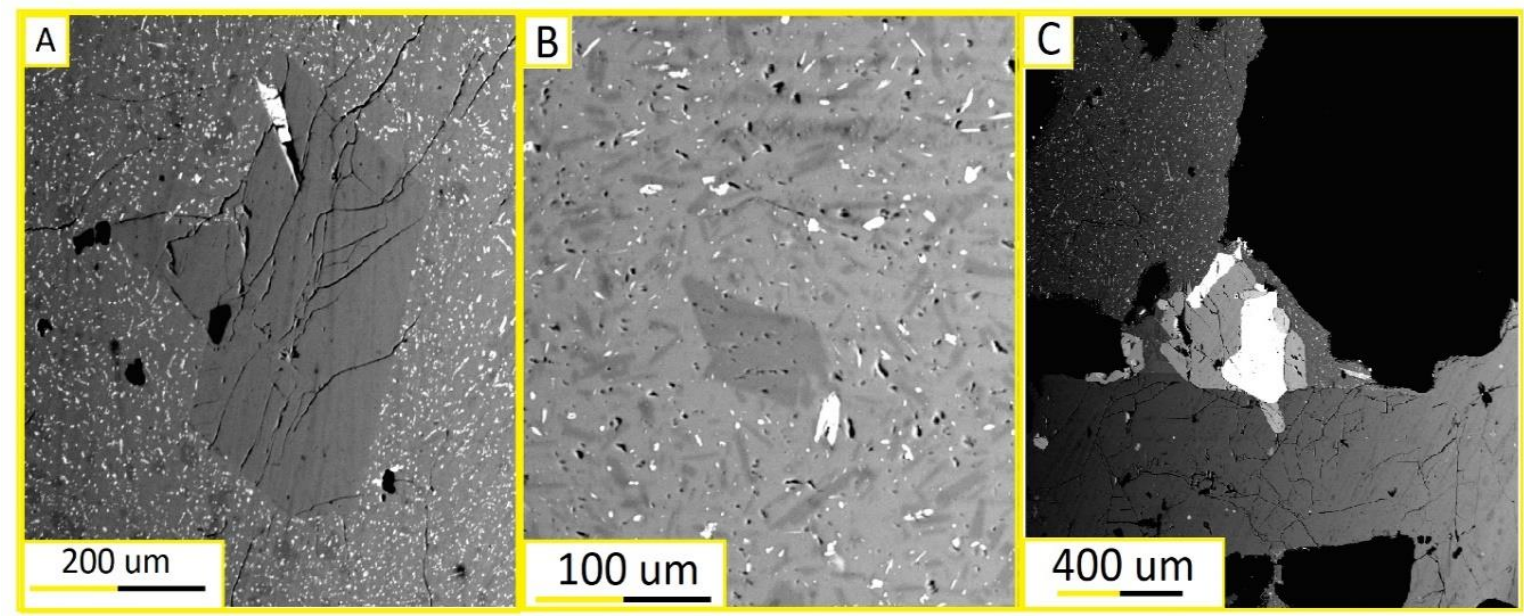

Figure 9.EMPA images for Plagioclase of 1921 eruptive event A) Plagioclase phenocryst sample 42825-plR5; B) Microlite sample 42823 b-pl-R1m .C) Cluster plagioclase from sample $42823 a$. 
clusters. The size of the grains is variable, but the majority have an average of 0.5 $\mathrm{mm}$ with larger grains, up to $5 \mathrm{~mm}$, belonging to mineral clusters (Fig.9).

The geochemical composition of the plagioclase crystals was obtained for six crystal grains per sample for 16 total phenocrysts and 14 microlite grains that plot in the andesite-oligoclase fields of the ternary classification triangle (Fig.10). The average molar fraction for Anorthite content is 0.39 for phenocrysts and 0.31 for microlites with a total range of $0.29-0.41$ (see Table 4 of appendix).

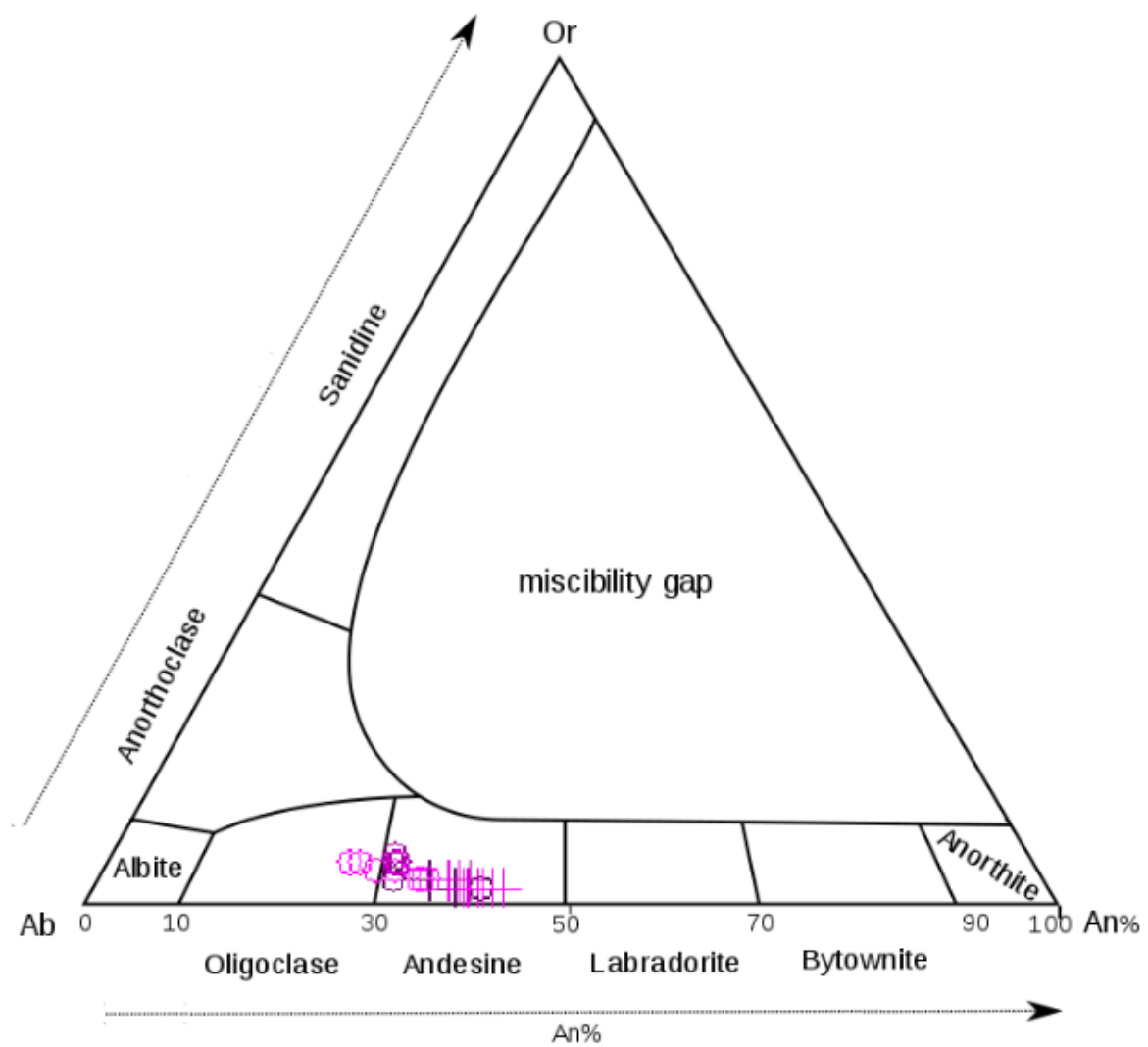

Figure 10. Ternary classification diagram Ab-An-Or EMPA data for 1921 eruptive event samples. In pink crosses represent phenocrysts and pink circles microlites measurements. 


\subsubsection{Pyroxenes}

An outstanding characteristic of all the samples is the presence of both $\mathrm{Cpx}$ and Opx in all rock samples (Fig 11). They are present as small phenocrysts dispersed in the groundmass or grouped in mineral clusters. Mostly all crystal grains are euhedral to subhedral with prismatic habits, but sometimes there is some disequilibrium evidence like reaction border textures or dissolved borders. Even though both phases are present in all samples, there is a level of heterogeneity in the overall volume of each phase, for example, sample 42828 has Opx as the more abundant crystal volume while sample 42823b and 42823a has Cpx as the dominant crystal phase. In both samples the Cpx has a strong presence of reaction or dissolved borders, and overall appears to be the less stable phase in all samples

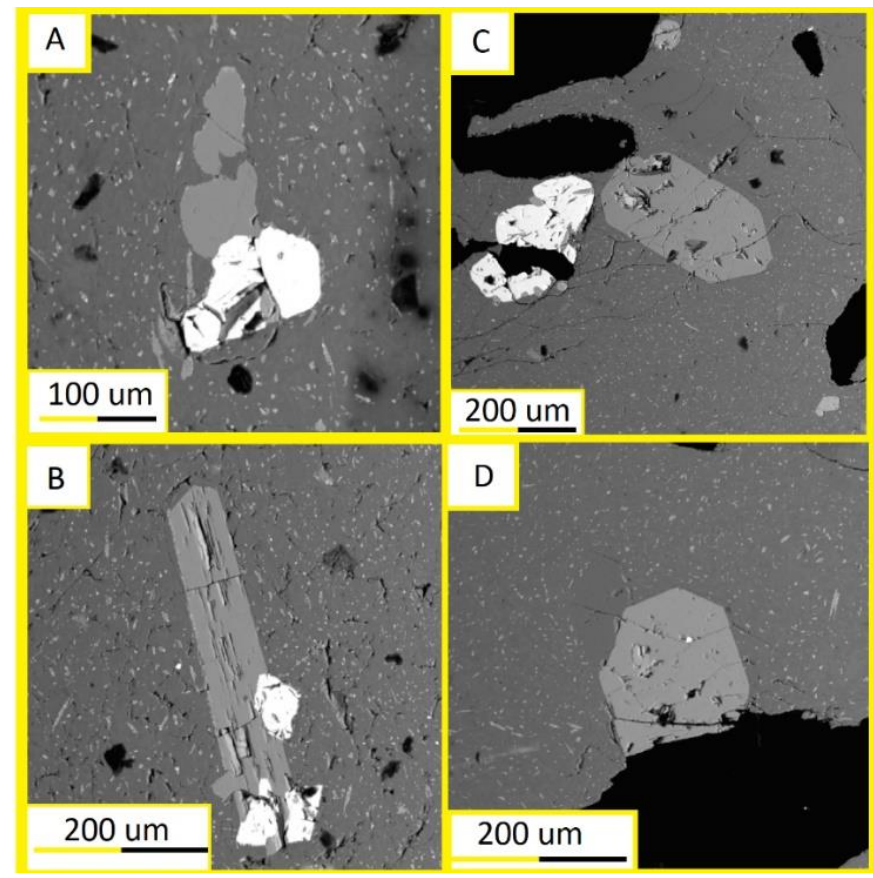

Figure 11. EPMA images of pyroxene crystals for 1921 eruptive event A) Cpx sample 42823a-px-R3; B) Opx sample 42823a-px-R3Ot; C) Cpx sample 42828-px-Cot; D) 42828-px-R3. 
Geochemically speaking, each phase is homogeneous across all samples, with average Wo: En: Fs molar fraction ratios in the order of 0.41:041:021 for Cpx grains, and 0.03:0.59:0.37 for Opx (Fig. 12). A full list of analysis can be seen in Table 7 of the appendix.

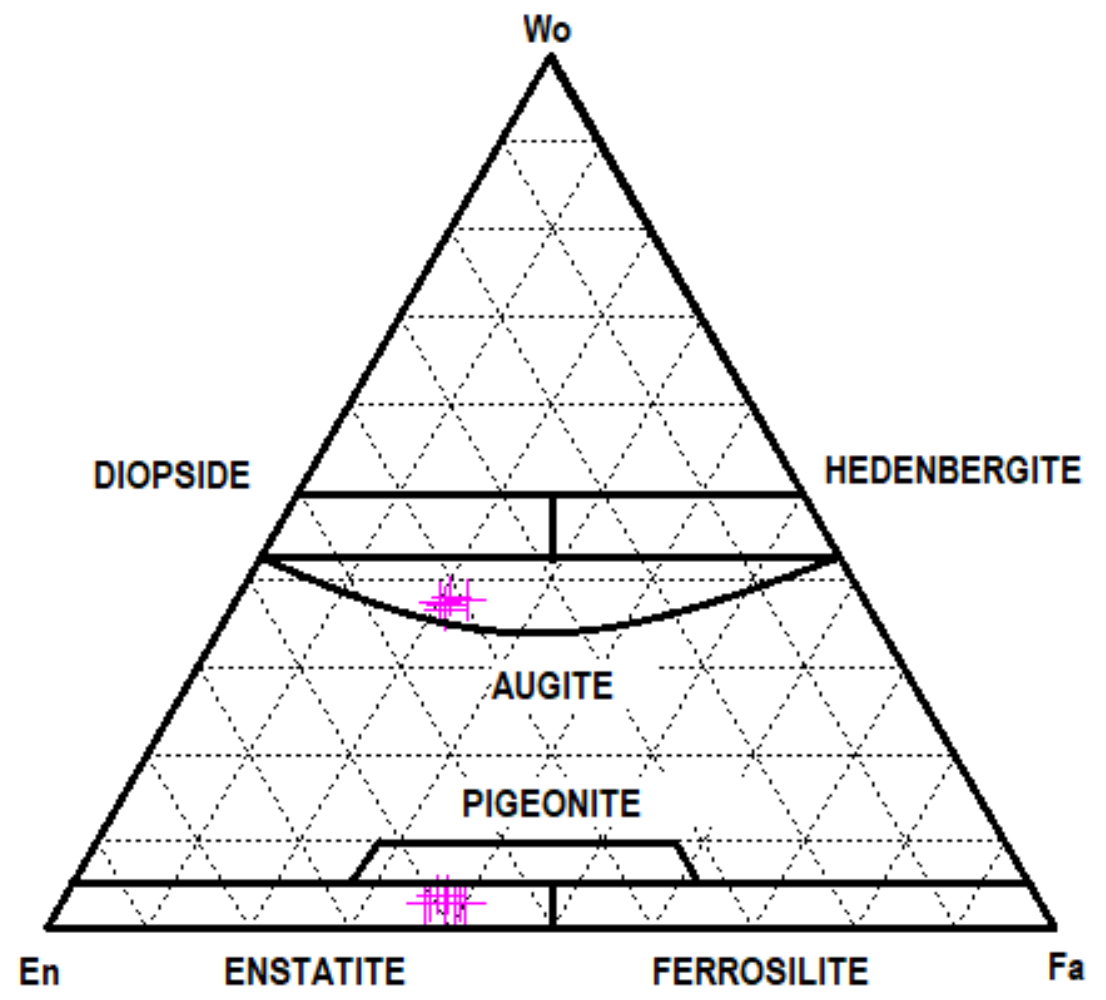

Figure 12. Pyroxenes classification ternary diagram for En: Wo: Fa phases. Pink crosses for EPMA data for pyroxene crystals of 1921 samples 


\subsubsection{Oxides}

Magnetite and ilmenite grains can be found throughout all the samples. They are fairly abundant and are either present as phenocrysts dispersed in the groundmass, inclusions in all other mineral phases (and usually together) and as mega-phenocrysts in the mineral clusters. The shape of the grains varies but are for the most part subhedral to anhedral and sometimes show signs of reequilibration (Fig.13).

Geochemically speaking the magnetite crystals show a high percentage of $\mathrm{TiO}_{2}$ with ranges from 16.48-18.23 wt\%. (Table 1 of the appendix).

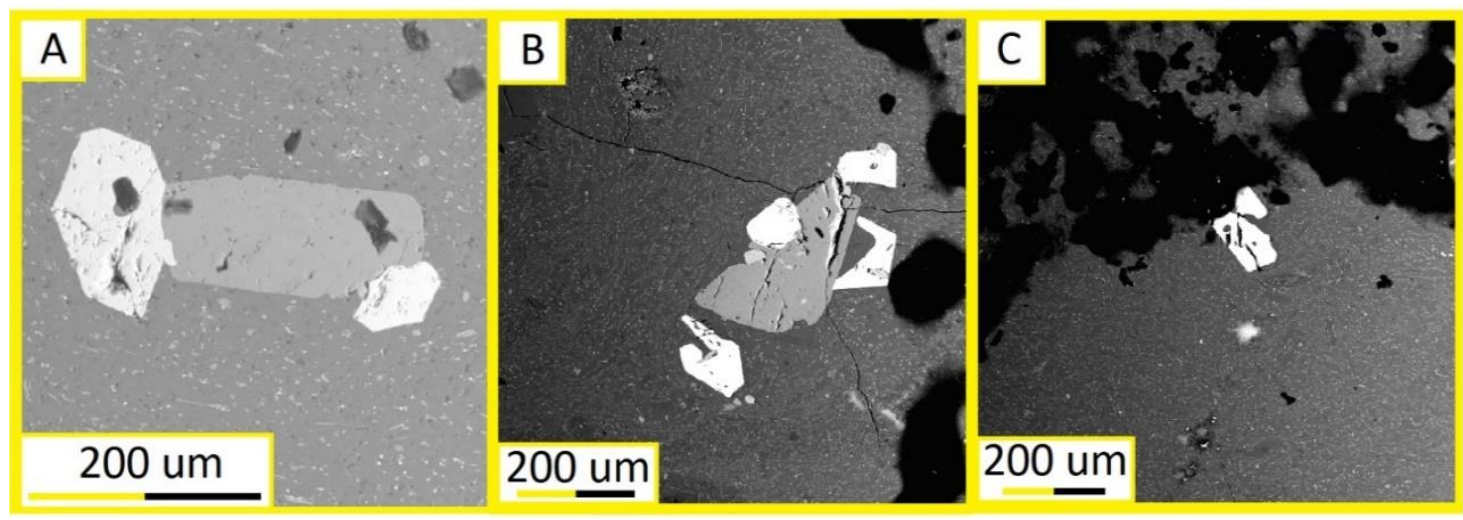

Figure 13. Oxide pairs for 1921 eruptive event. A) inclusion on px crystal pair 72822-Br1m; B) inclusion on pyroxene crystal 42825-R3 C) touching pair 42825-R1.

\subsubsection{Temperature and Oxygen Fugacity}

The 1921 event calculated temperatures (Table 3) have an average value of $940^{\circ} \mathrm{C}$ and is quite stable throughout all rock samples. As discussed before, the standard deviation for the measurements are below the model error therefore the values are safely applicable for at least \pm 20 degrees. The lowest estimate is 920 ${ }^{\circ} \mathrm{C}$ belonging to the TG2 (obsidian no vesicles) and the highest being $973{ }^{\circ} \mathrm{C}$ for 
TG1 (Hyalopilitic, no vesicles), however there seems to be no direct relation for temperature measurements and textural characteristics of the rocks.

As for the calculated oxygen fugacity, the average for the unit is -0.22 however there is a flow that presents a considerable higher value of -0.40 and it does seem to coincide with the sample with highest volume of vesicles.

Table 3. Ghiorso and Evans (2008), thermometry and oxygen fugacity relative to NNO buffer. Average results per sample for 1921 eruptive event.

\begin{tabular}{|l|c|c|c|}
\hline \multicolumn{1}{|c|}{ Sample } & Rock texture & Average Temperature ${ }^{\circ} \mathrm{C}$ & Average Fugacity \\
\hline 42825 & TG1 & 973 & -0.15 \\
\hline 72822 & TG4 & 953 & -0.14 \\
\hline $42823 a$ & TG2 & 920 & -0.40 \\
\hline $42823 b$ & TG4 & 951 & -0.16 \\
\hline 42828 & TG3 & 952 & -0.26 \\
\hline & Total average & 950 & -0.22 \\
\hline
\end{tabular}

\subsubsection{Water Content}

The water content measurements utilizing Waters and Lange (2015) hygrometer model was performed on two populations: 1) plagioclase phenocrysts, that are in equilibrium with the liquid, possibly representing the conditions of the magmatic chamber, and, 2) microlites of plagioclase that may represent post eruptive processes like decompression or degassing crystallization. The results show little variation across all flows (Table 4) with average calculated weight percentage of 2.57 for phenocrysts and 2.44 for microlites showing $0.13 \%$ total difference between the phenocrysts and the microlites. The difference is below the 
average error of the model but is also consistently present across almost all samples. The calculated measurements do not show a direct relation with the different rock textures, however, the sample representing TG2 is considerably higher than the rest of the samples; the other value that stands out is for sample 2123b (TG4) that shows almost no difference in between phenocrystal and microlites estimates.

It is important to note that the water content in this hygrometer model is highly sensitive to temperature measurements, for that reason, in a later section, different scenarios will be explored.

\begin{tabular}{|c|c|c|c|c|}
\hline Sample & $\begin{array}{l}\text { Texture } \\
\text { group }\end{array}$ & $\begin{array}{l}\text { Average } \mathrm{H}_{2} \mathrm{O} \\
\text { wt\% phenocrysts }\end{array}$ & $\begin{array}{l}\text { Average } \mathrm{H}_{2} \mathrm{O} \text { wt\% } \\
\text { Microlites }\end{array}$ & Difference \\
\hline 42825 & TG1 & 2.13 & 1.98 & 0.15 \\
\hline $42823 b$ & TG4 & 2.51 & 2.48 & 0.03 \\
\hline 72822 & TG4 & 2.54 & 2.38 & 0.16 \\
\hline 42828 & TG3 & 2.51 & 2.36 & 0.15 \\
\hline $42823 a$ & TG2 & 3.16 & 3.01 & 0.15 \\
\hline \multicolumn{2}{|c|}{ Total Average } & 2.57 & 2.44 & 0.13 \\
\hline
\end{tabular}




\subsection{Cordon Caulle 1960 eruption}

Five volcanic rock samples from the effusive stage of the eruptive event are selected for this unit; each sample represents a different flow covering most of the 5.5-km-long fissure system where 21 vents were sited (Lara et al, 2006b), located near the SW margin of the PCCVC. (Fig. 14)

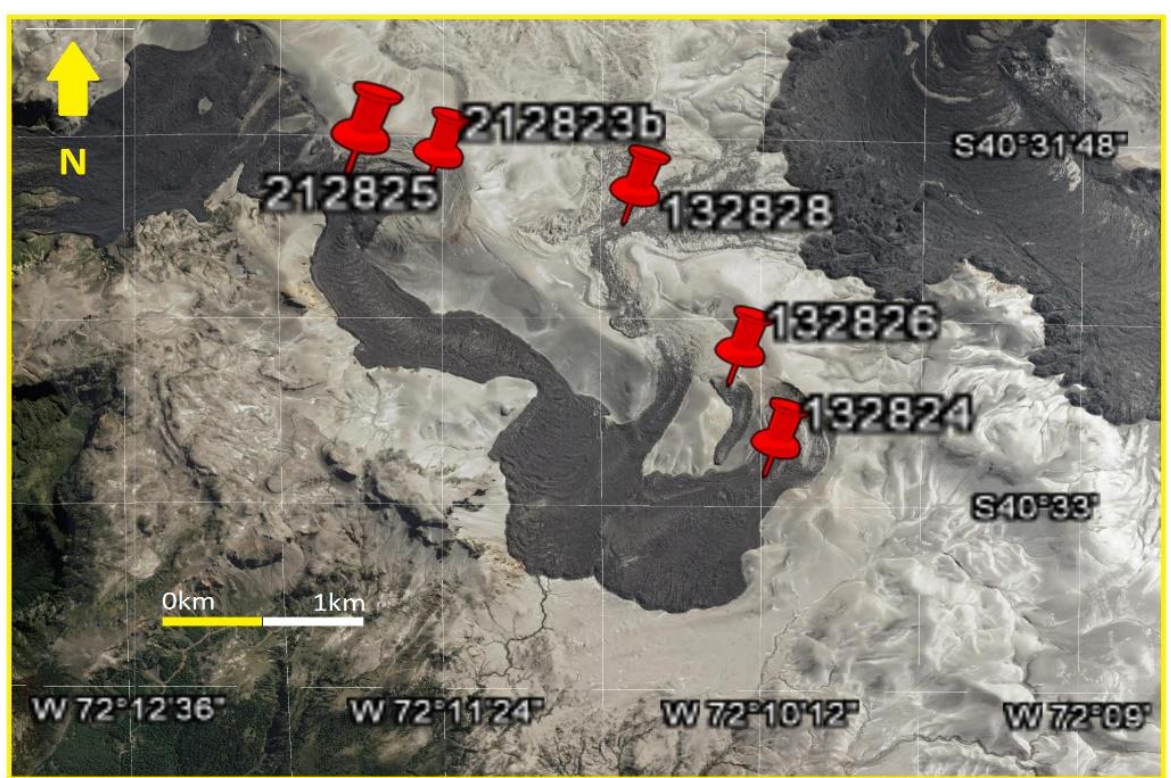

Figure 14. Selected samples distribution for 1960 eruptive event

\subsubsection{Petrography}

All samples for this unit have vitrophyric textures and holohyaline to hyalopilitic ground mass textures. The groundmass usually has flow bands and occasionally trachytic textures for microlites. The rock sample with highest phenocrystal volume is the sample representing TG4 and one sample from TG3 
with approximately $10 \%$, while the rest of the samples have an estimated average of $7 \%$ (slightly higher than the 1921 event). All phenocrysts have the same mineral compositions in all samples with the same mineral phases present in 1921 event, $\mathrm{PI}, \mathrm{Cpx}, \mathrm{Opx}, \mathrm{Mgt}, \mathrm{III} \pm \mathrm{Ap}, \mathrm{Zr}$. Just as for the 1921 event, the same ratio of 10:1 for plagioclase over the mafic minerals is maintained and the mafic dominance of Cpx and Opx varies from sample to sample but most commonly the Cpx is slightly more abundant. The size of the crystal grains is bimodal depending on presence of grain clusters that have crystals up to $2 \mathrm{~mm}$ for plagioclase, while the average size for the plagioclase phenocrysts is $0.75-0.5 \mathrm{~mm}$; the same trends stands for all the mineral components (Table 27 of the appendix).

\subsubsection{Geochemistry and Minerals compositions}

The bulk composition of the rocks is taken from Gerlach et al (1988) and can be observed in Table 5. The $\mathrm{SiO}_{2}$ content from the 1960 eruptive event ranges in between 69 and $70 \mathrm{wt} \%$ and can be classified as rhyolites (Fig. 20), with an average sum of alkali components of $7.22 \mathrm{wt} \%$. and total water content wt\% between $0.11-0.21$. 


\begin{tabular}{|c|c|c|c|c|c|c|c|}
\hline \multirow{2}{*}{$\begin{array}{l}\text { Event } \\
\text { Sample }\end{array}$} & \multicolumn{7}{|c|}{1960} \\
\hline & CVI-D1 & CVI-D2 & CVI-D3 & CVI-D4 & CVI-R1 & CVI-D5 & CVI-D6 \\
\hline $\mathrm{SiO}_{2}$ & 69.73 & 69.92 & 69.52 & 69.83 & 70.01 & 69.62 & 69.00 \\
\hline $\mathrm{TiO}_{2}$ & 0.70 & 0.68 & 0.68 & 0.70 & 0.65 & 0.67 & 0.69 \\
\hline $\mathrm{Al}_{2} \mathrm{O}_{3}$ & 14.18 & 14.11 & 14.18 & 14.20 & 14.06 & 14.13 & 14.07 \\
\hline $\mathrm{MnO}$ & 0.10 & 0.11 & 0.09 & 0.12 & 0.11 & 0.11 & 0.14 \\
\hline $\mathrm{MgO}$ & 0.50 & 0.48 & 0.46 & 0.46 & 0.43 & 0.45 & 0.64 \\
\hline $\mathrm{FeO}$ & 4.59 & 4.48 & 4.46 & 4.53 & 4.34 & 4.43 & 4.50 \\
\hline $\mathrm{K} 2 \mathrm{O}$ & 2.73 & 2.75 & 2.77 & 2.72 & 2.80 & 2.75 & 2.68 \\
\hline $\mathrm{Na} 2 \mathrm{O}$ & 5.01 & 5.13 & 5.50 & 5.09 & 4.99 & 5.05 & 5.40 \\
\hline $\mathrm{CaO}$ & 2.24 & 2.15 & 2.19 & 2.23 & 2.15 & 2.15 & 2.25 \\
\hline $\mathrm{P}_{2} \mathrm{O}_{5}$ & 0.14 & 0.14 & 0.14 & 0.14 & 0.14 & 0.14 & 0.16 \\
\hline $\mathrm{H}_{2} \mathrm{O}$ & 0.13 & 0.12 & 0.14 & 0.21 & 0.11 & 0.11 & 0.21 \\
\hline Total & 99.92 & 99.95 & 99.99 & 100.02 & 99.56 & 99.50 & 99.53 \\
\hline
\end{tabular}

\subsubsection{Plagioclases}

Plagioclase is the dominant phase among all the phenocrysts in all rock samples. They are present as euhedral, prismatic grains of $0.5 \mathrm{~mm}$ average size, with polysynthetic twinning, however bigger mega-phenocrysts up to $2 \mathrm{~mm}$ are present in mineral clusters and are usually zoned. (Fig. 15)

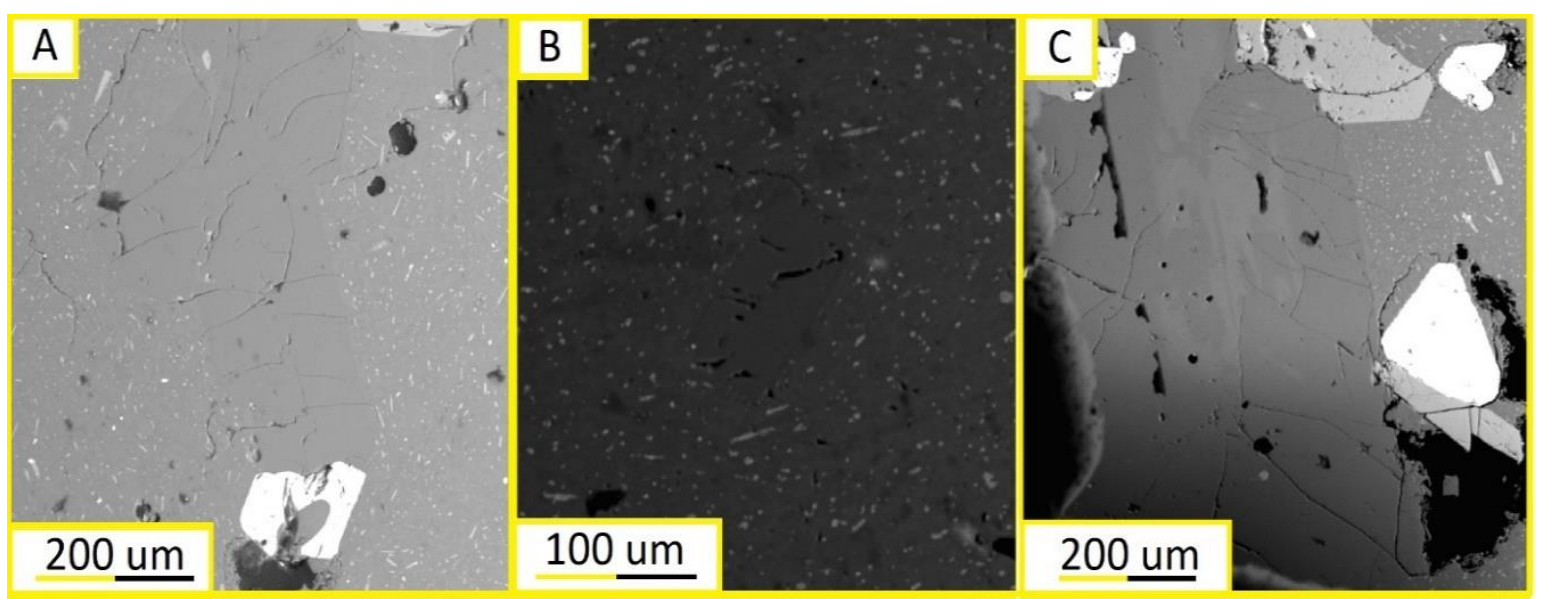

Figure 15. EPMA images for Plagioclase grains of 1960 eruptive event. A) Plagioclase phenocryst 132824apl-A1. B) Microlite example 132828-pl-E1 .C) Cluster plagioclase 132826-PI-A1 
In the classification diagram, the average geochemical components for the phenocrysts fall in the Andesine classification group with an average molar fraction of 0.35 Anorthite content, while the microlites fall mostly in the Oligoclase group with 0.26 , for a total range of 0.21 to 0.35 (Fig. 16). The full analysis list can be seen in Table 5 of the appendix.

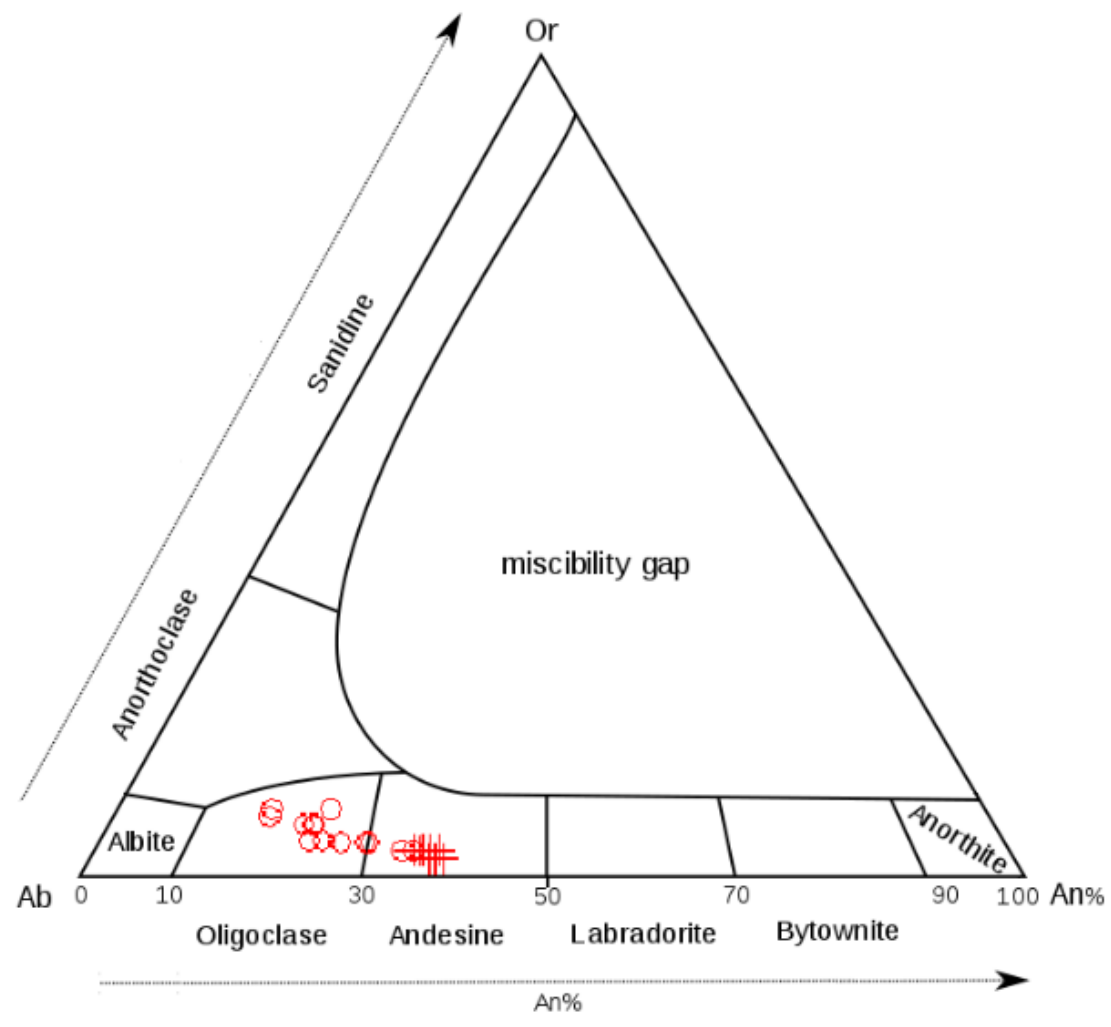

Figure 16. Ternary classification diagram Ab-An-Or. EMPA data for 1960 eruptive event samples. In red crosses phenocrysts and red circles microlites measurements. 


\subsubsection{Pyroxenes}

Just as in the 1921 event all the samples contain the presence of Cpx, and Opx (Fig. 17).

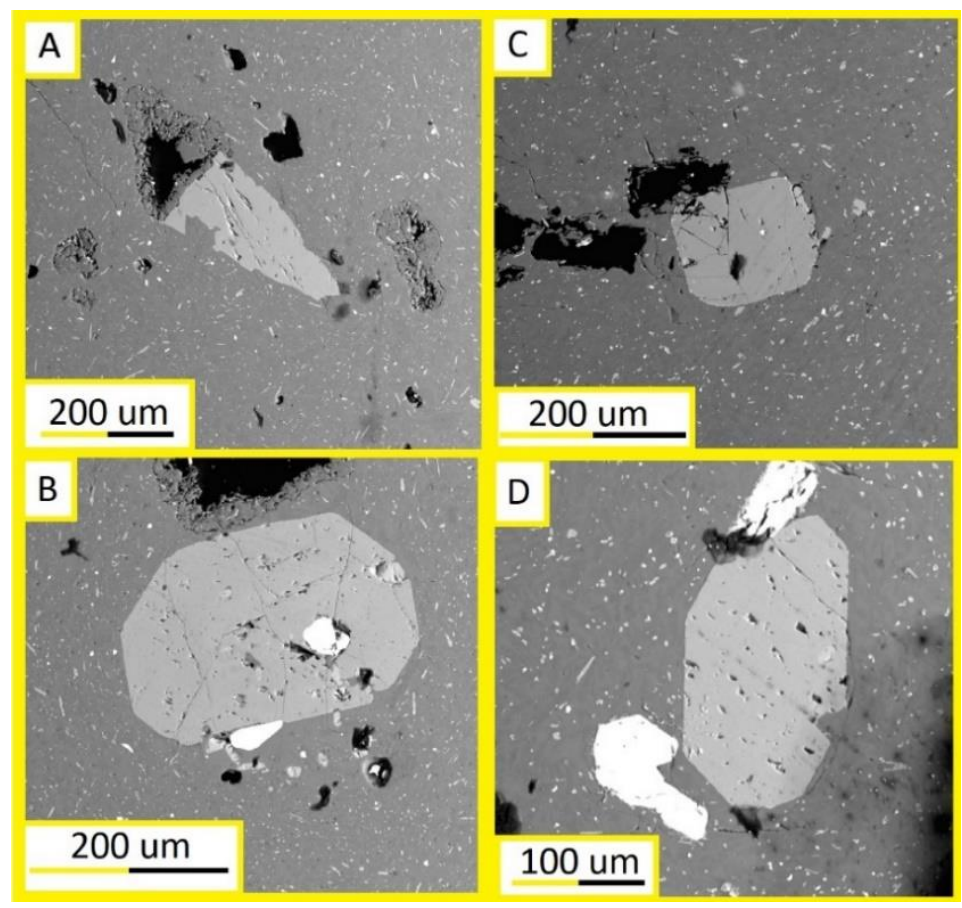

Figure 17 Emp images of pyroxene crystals A) Cpx 132824a-px-R1; B) Opx 132824a-R2ot; c) Clxp-132828-px-Got; D) Opx 132828-px-H

The textural and chemical characteristics of the 1960 event is very similar to that of 1921 , the pyroxene crystals show the same variations, with similar euhedral to subhedral prismatic grains and occasional evidence of disequilibrium such as reaction or dissolved borders. Just as the 1921 event there are some variations in volume of phenocrysts where there is a strong dominance of Cpx. Such is the case for the 212825 sample and a slight dominance in sample 132828, while the rest have basically the same ratio. However, Opx grains are on average of smaller size. The Cpx usually presents reaction borders being relatively less stable than 
the Opx grains especially in cluster grains except for sample 212825 where little evidence of disequilibrium is present on both phases.

Geochemically speaking, the average Wo:En:Fa molar fraction ratios are: 0.35:0.43:0.26 for Cpx grains, and 0.03:0.55:0.41 for Opx, showing almost identical compositions in all samples and to the previous eruptive event (Fig. 18). The full list of analysis can be seen in Table 8 of the appendix.

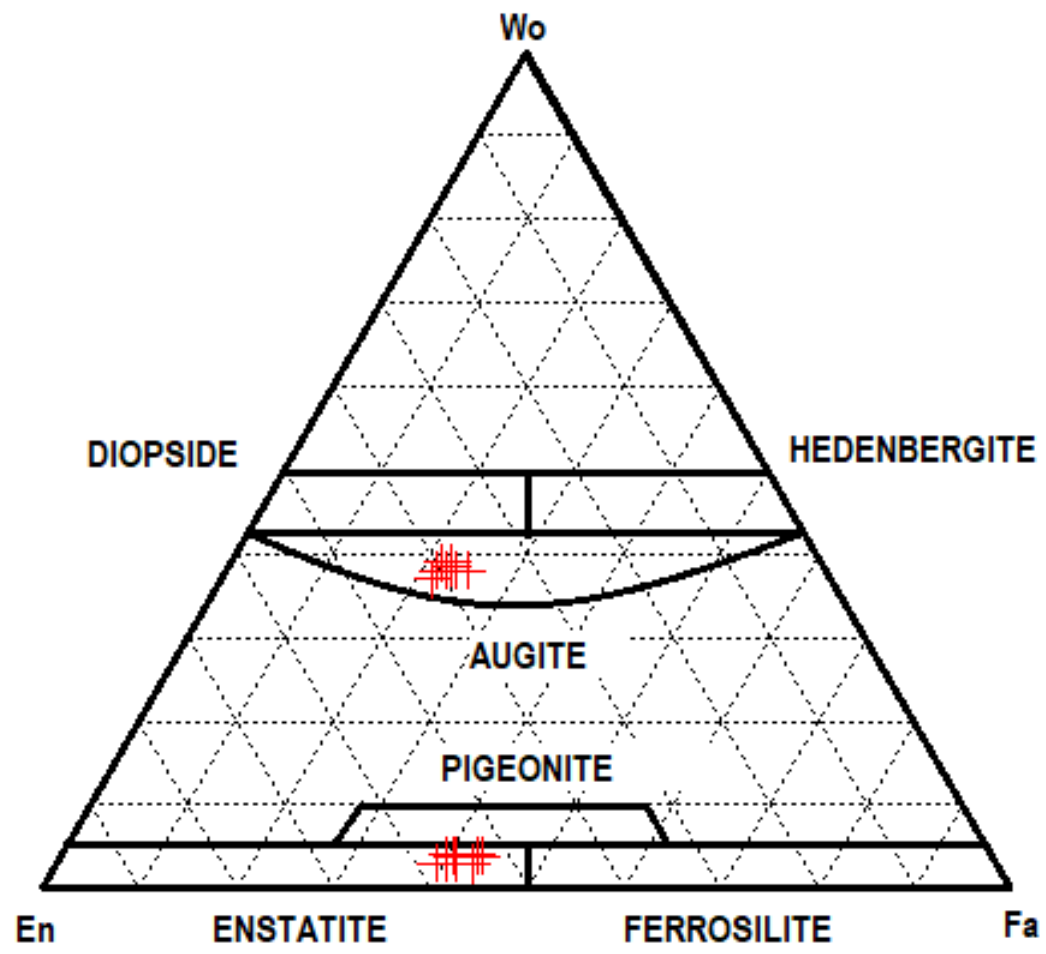

Figure 18. Pyroxenes classification ternary diagram for En: Wo: Fa phases. Red crosses for EPMA data for pyroxene crystals of 1921 samples 


\subsubsection{Oxides}

Magnetite and ilmenite crystals are both present and are relatively abundant in all samples. They can be found either as phenocrysts dispersed in the groundmass, inclusions in all other mineral phases (and usually together), and as mega-phenocrysts in mineral clusters. The shape of the grains varies but for the most part they are subhedral to anhedral and sometimes shows signs of reequilibration. Geochemically speaking, the magnetite crystals show a high percentage of $\mathrm{TiO}_{2}$ with a total range of 24.52-16.33 wt\% (Table 2 of the appendix).
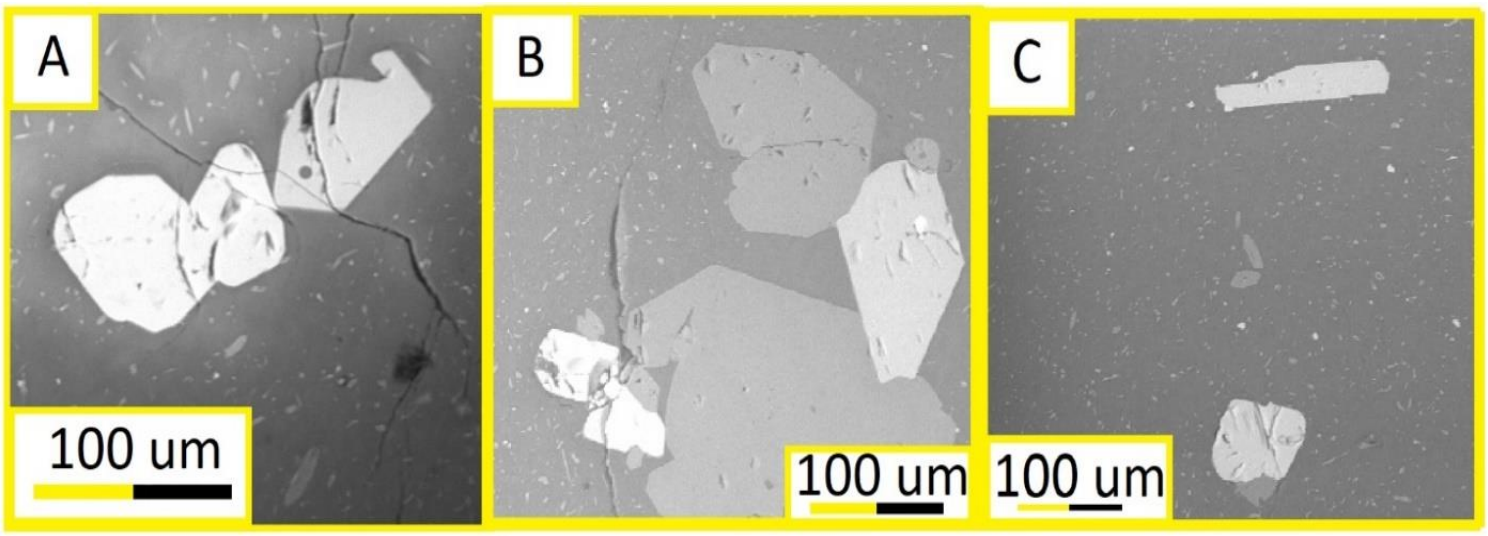

Figure 19. EPMA images for 1960 eruptive event of: A) touching ilmenite -magnetite pair sample $132824 x ; B)$ ilmenite and magnetite pair inclusion of Cpx, from sample 128236-EX; C) Adjacent ilmenite Magnetite pair from sample 212825-F.

\subsubsection{Temperature and Oxygen Fugacity}

The acquired temperature for this event (Table 6) averages $940{ }^{\circ} \mathrm{C}$ and is quite stable throughout all rock samples. As discussed before, the standard deviations for the measurements are below the model error therefore the values are safely applicable for at least \pm 20 degrees, where the lowest measured is 909 
${ }^{\circ} \mathrm{C}$ belonging to the TG3 (interconnected vesicles) and the highest being $963{ }^{\circ} \mathrm{C}$ from TG4 (obsidian without vesicles).

As for the calculated oxygen fugacity, the average for the unit is -0.44 however there is a flow that presents a considerably less negative value of -0.22 belonging to the obsidian sample.

Table 6. Ghiorso and Evans (2008), thermometry and oxygen fugacity relative to NNO buffer. Average results per sample for 1960 eruptive event.

\begin{tabular}{|c|c|c|c|}
\hline Sample & Texture group & Average Temperature ${ }^{\circ} \mathrm{C}$ & Average Fugacity \\
\hline $132824 \mathrm{a}$ & TG1 & 932 & -0.48 \\
\hline $212823 \mathrm{~b}$ & TG4 & 963 & -0.22 \\
\hline 132828 & TG3 & 939 & -0.49 \\
\hline 212825 & TG3 & 909 & -0.53 \\
\hline 132826 & TG2 & 954 & -0.48 \\
\hline \multicolumn{2}{|c|}{ Total average } & 940 & -0.44 \\
\hline
\end{tabular}

\subsubsection{Water Content}

Just as the 1921 flows, the water calculations represent: 1) phenocrysts and 2) microlites in the ground mass. The results also show little variation across all flows (Table. 7) with average calculated weight percentage of 2.67 for phenocrysts and 2.49 for microlites showing $0.18 \%$ difference between them, below the 
average error of the model but just as the 1921 event the difference is stable throughout all samples. The calculated results do not show a direct relation with the different rock textures as it does with the temperature. Accounting for the strong relation between these two variables different calculations, depending on varying temperature scenarios, will be analyzed in a later section.

\begin{tabular}{|c|c|c|c|c|}
\hline Sample & Texture group & $\begin{array}{c}\text { Average } \mathrm{H}_{2} \mathrm{O} \\
\text { wt\% phenocrysts }\end{array}$ & $\begin{array}{l}\text { Average } \mathrm{H}_{2} \mathrm{O} \text { wt } \% \\
\text { Microlites }\end{array}$ & Difference \\
\hline $132824 a$ & TG2 & 2,86 & 2,67 & 0,19 \\
\hline 212823b & TG4 & 2.15 & 2.03 & 0,12 \\
\hline 132828 & TG3 & 2.76 & 2.69 & 0.07 \\
\hline 212825 & TG3 & 3.22 & 3.05 & 0.17 \\
\hline 132826 & TG1 & 2.30 & 2.03 & 0.27 \\
\hline \multicolumn{2}{|c|}{ Total Average } & 2.67 & 2.49 & 0.18 \\
\hline
\end{tabular}




\subsection{Cordon Caulle 2011 eruption}

Two samples were analyzed from 2011 event; 1) a lava flow rock representing the principal flow of the effusive phase, that resembles the TG3 (interconnected vesicles), and 2) a pumice sample categorized as TG5. Also, since the event has been studied, results of geochemical analysis and pre-eruptive variables calculated by Castro et al. (2013) are also added for comparison to the new results.

\subsubsection{Petrography}

The flow sample from the 2011 event represents the TG3 where the vesicles represent a $5 \%$ total volume of the rock with irregular shape and high level of interconnectivity concentrated in bands. However, a distinctive feature from the other TG3 samples is that the vesicles can have amygdaloid texture filled with plagioclase. The overall percentage of phenocrysts is estimated to be $5-7 \%$ with dominance of plagioclase over the mafic minerals. Even though clusters of crystals are rare, the highly variable size of the phenocrysts indicates that there may be some that come from deeper source with plagioclase grains having sizes range between $1 \mathrm{~mm}$ to $0.1 \mathrm{~mm}$. The mafic mineral phases in this samples are lower in volume compared to the previous events.

\subsubsection{Geochemistry and Minerals compositions}

The overall bulk composition of the eruptive material for 2011 event (Table

8) as well as the REE analysis show that the range is almost identical to the 1960 
flows and slightly richer in silica content than the 1921 event (Castro et al., 2013) plotting in the rhyolite category (Fig. 20).

Table 8. Geochemical data taken from Water and Lange (2015) based on Castro et al. (2013) measurements.

\begin{tabular}{|c|cccccccc|c|}
\hline Sample & $\begin{array}{c}\mathrm{SiO}_{2} \\
(\mathbf{w t} \%)\end{array}$ & $\begin{array}{c}\mathrm{TiO}_{2} \\
(\mathbf{w t} \%)\end{array}$ & $\begin{array}{c}\mathrm{Al}_{2} \mathbf{O}_{3} \\
(\mathbf{w t} \%)\end{array}$ & $\begin{array}{c}\mathbf{F e O} \\
(\mathbf{w t} \%)\end{array}$ & $\begin{array}{c}\mathbf{M g O} \\
(\mathbf{w t} \%)\end{array}$ & $\begin{array}{c}\mathbf{C a O} \\
(\mathbf{w t} \%)\end{array}$ & $\begin{array}{c}\mathrm{Na}_{2} \mathbf{O} \\
(\mathbf{w t} \%)\end{array}$ & $\begin{array}{c}\mathbf{K}_{2} \mathbf{O} \\
(\mathbf{w t} \%)\end{array}$ & Total \\
\hline Puy 10 & 70.5 & 0.62 & 14.4 & 3.23 & 0.52 & 1.88 & 5.69 & 2.86 & 98.8 \\
Puy 15 & 72.4 & 0.47 & 14.4 & 2.36 & 0.33 & 1.41 & 5.29 & 3.04 & 98 \\
Puy 17 & 72.8 & 0.29 & 14.8 & 1.75 & 0.26 & 1.49 & 5.42 & 2.96 & 93.8 \\
Puy 2 & 73 & 0.32 & 14.5 & 2.02 & 0.28 & 1.45 & 5.01 & 3 & 94.1 \\
Puy 9 & 72.4 & 0.46 & 13.8 & 2.6 & 0.34 & 1.36 & 5.53 & 3.08 & 98.7 \\
\hline Average & 72.22 & 0.43 & 14.38 & 2.39 & 0.35 & 1.52 & 5.39 & 2.99 & 96.68 \\
\hline
\end{tabular}

a

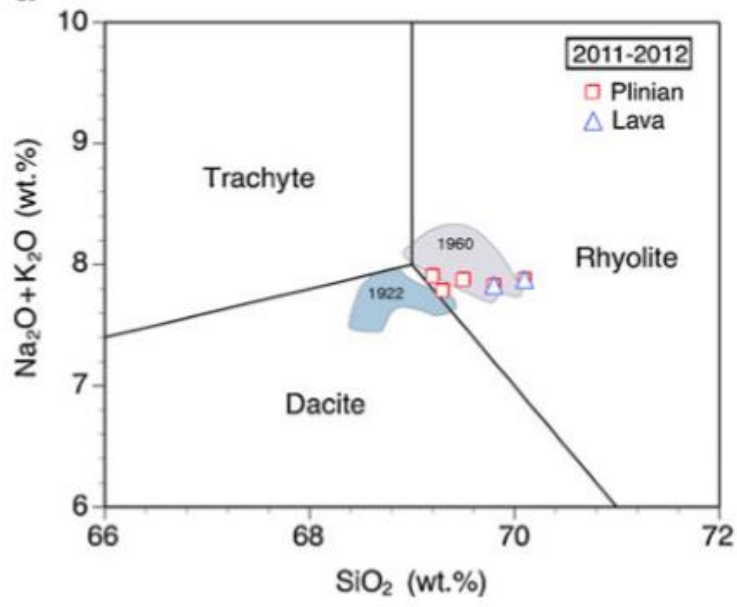

b

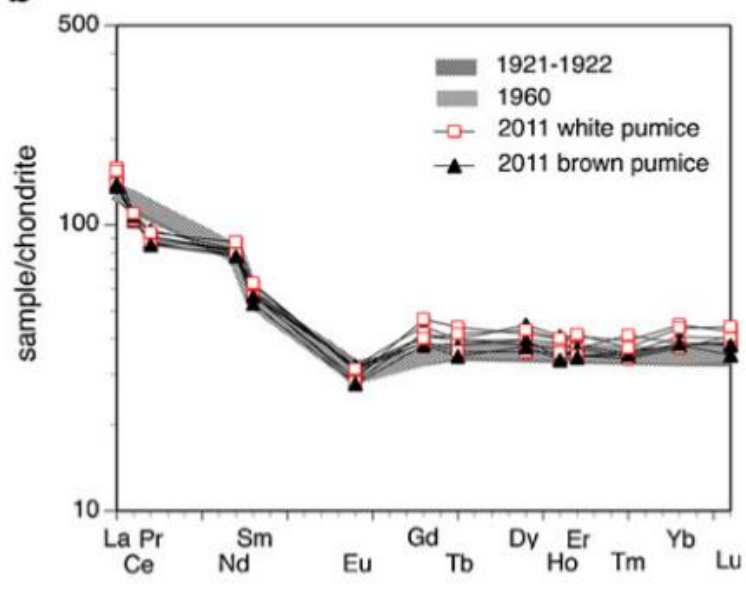

Figure 20. A) Major-element TAS diagram after Le Bas and Streckeisen (1991). B) and chondritenormalized REE element chemistry of the 2011 Cordón Caulle rhyolite. Image taken from Castro et al. (2013). 


\subsubsection{Plagioclase}

Plagioclase is the main phenocryst phase of the lava samples and, just as the other two eruptive events, the crystals are euhedral un-zoned with polysynthetic twinning with little evidence of disequilibrium. However, contrary to other samples the sizes are more dispersed covering a wide range of sizes from $1 \mathrm{~mm}-0.2 \mathrm{~mm}$. The bigger crystals can be zoned but there are fewer clusters compared to the other two previous eruptive events (Fig. 21).
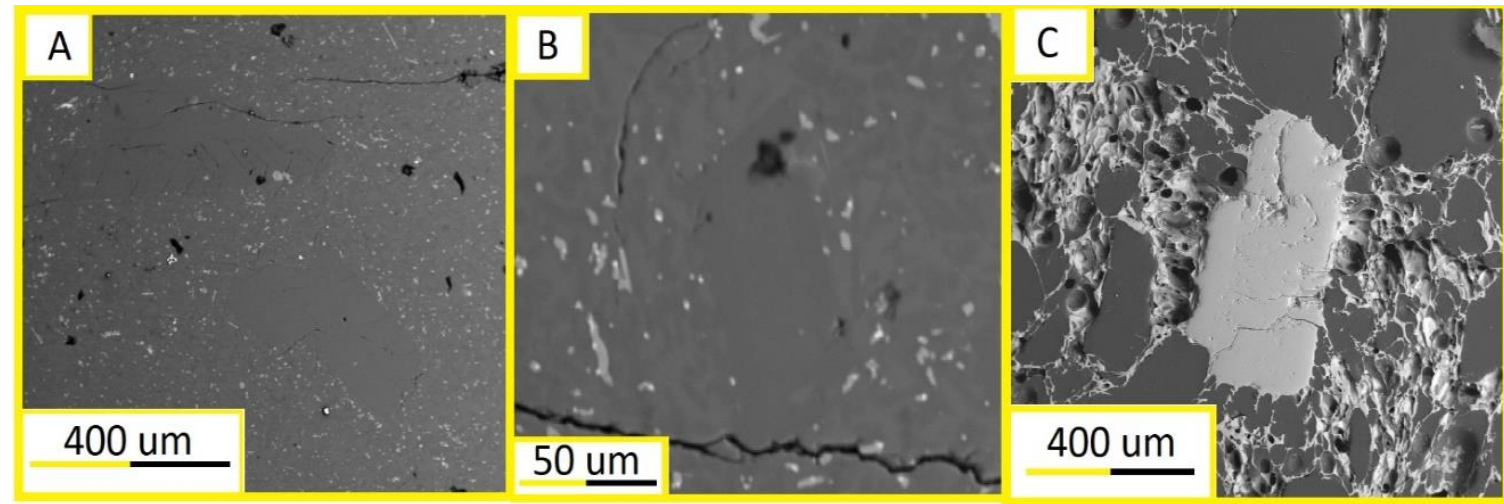

Figure 21. EMPA images for Plagioclase grains. A) Plagioclase phenocryst Dtccl11-pl-D. B) Microlite Dtccl11-pl-em .C) Pumice plagioclase crystal Pmh11-pl-1

The grains acquired from the pumice sample all plot in the Andesine field while the lava phenocrysts plot in Andesine and microlites are placed in the Oligoclase field. Since there is limited sample for the event, the data are also compared to Castro et al. (2013), and as can be observed in Fig. 22, the measured plagioclase compositions are equivalent to the newly acquired data. The full list of analyses can be seen in Table 5 of the appendix. 


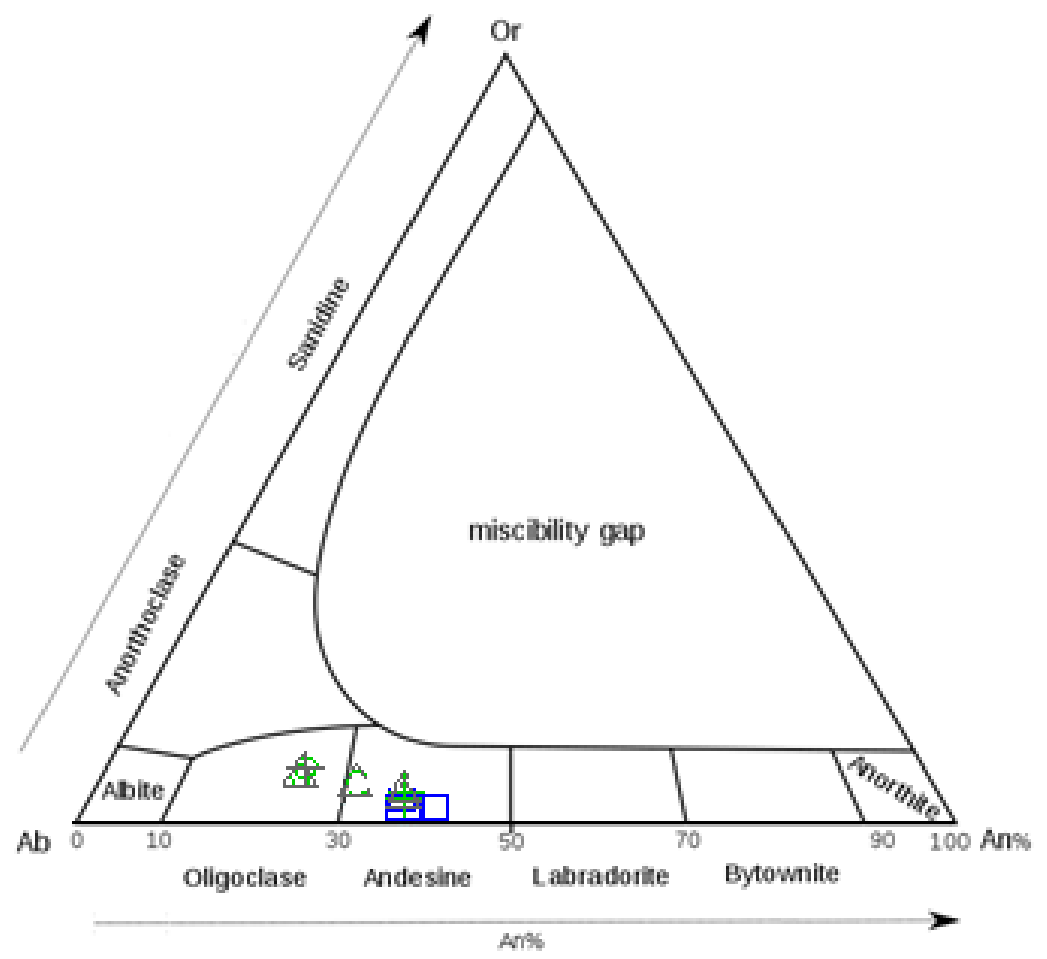

Figure 22. Ternary classification diagram Ab-An-Or EPMA data for 2011 eruptive event samples. In green crosses phenocrysts and green circles microlites measurements in blue squares measurements from Castro et al. (2013)

\subsubsection{Pyroxenes}

Just as the other events, both types of pyroxene crystals are present as phenocrysts in the groundmass, or as part of clusters with the rest of the mineral phases. There is a slight dominance of Opx over Cpx. The phenocrysts sizes ranges between 0.5 and $0.2 \mathrm{~mm}$ for $\mathrm{Cpx}$, and smaller sizes for Opx. The Cpx phase always has reaction borders and sometimes dissolved borders on bigger grains while the Opx phase seems to be more stable but some grains do have reaction borders (Fig. 23). 


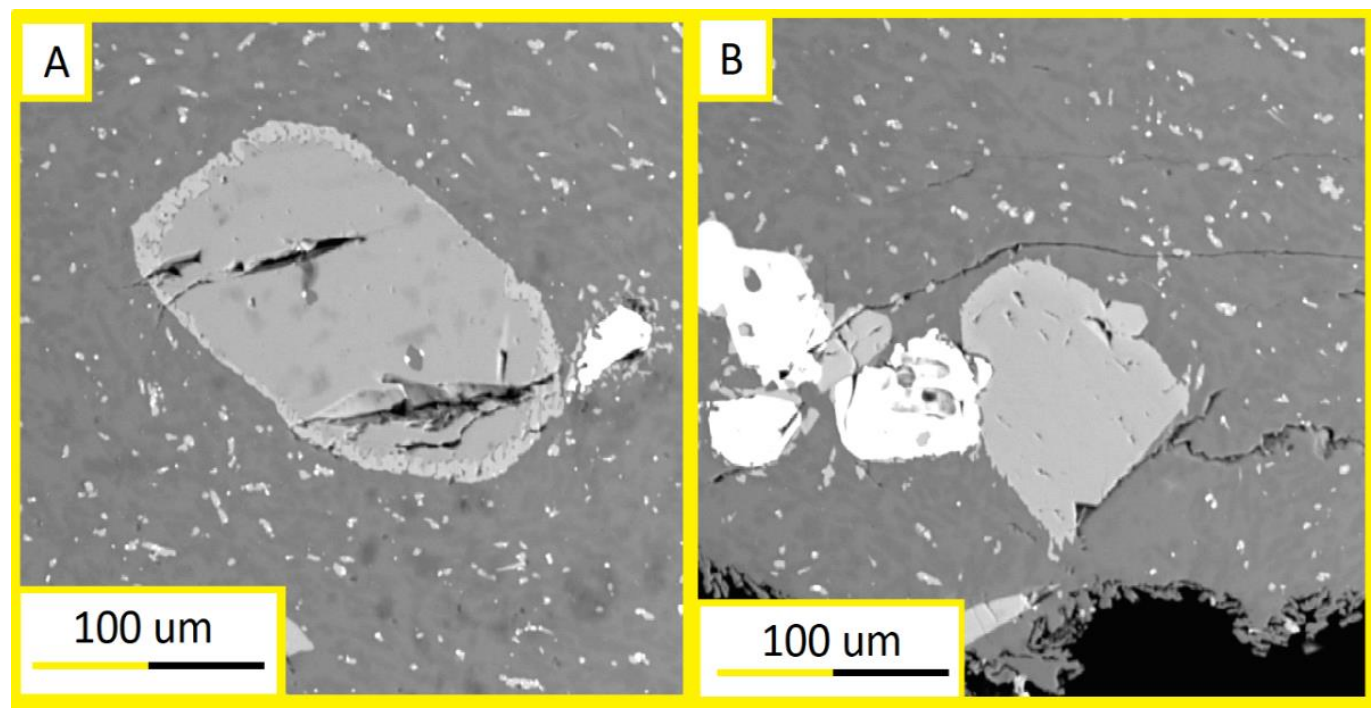

Figure 23. EMP images for Pyroxene Phenocrysts pf 2011 eruptive event. A) Cpx Sample Dtccl11-px-F; B) Opx sample Dtccl11-Px-R3.

Geochemically speaking, the compositions are just as homogeneous as previous events plotting in either Enstatite fields for Opx or Augites for Cpx. The data are compared to Castro et al. (2013), and are consistent with those measurements, however the results from that study show more variation of pyroxene compositions not found in the lava sample (Fig 24). The full list of analyses can be seen in Table 9 of the appendix. 


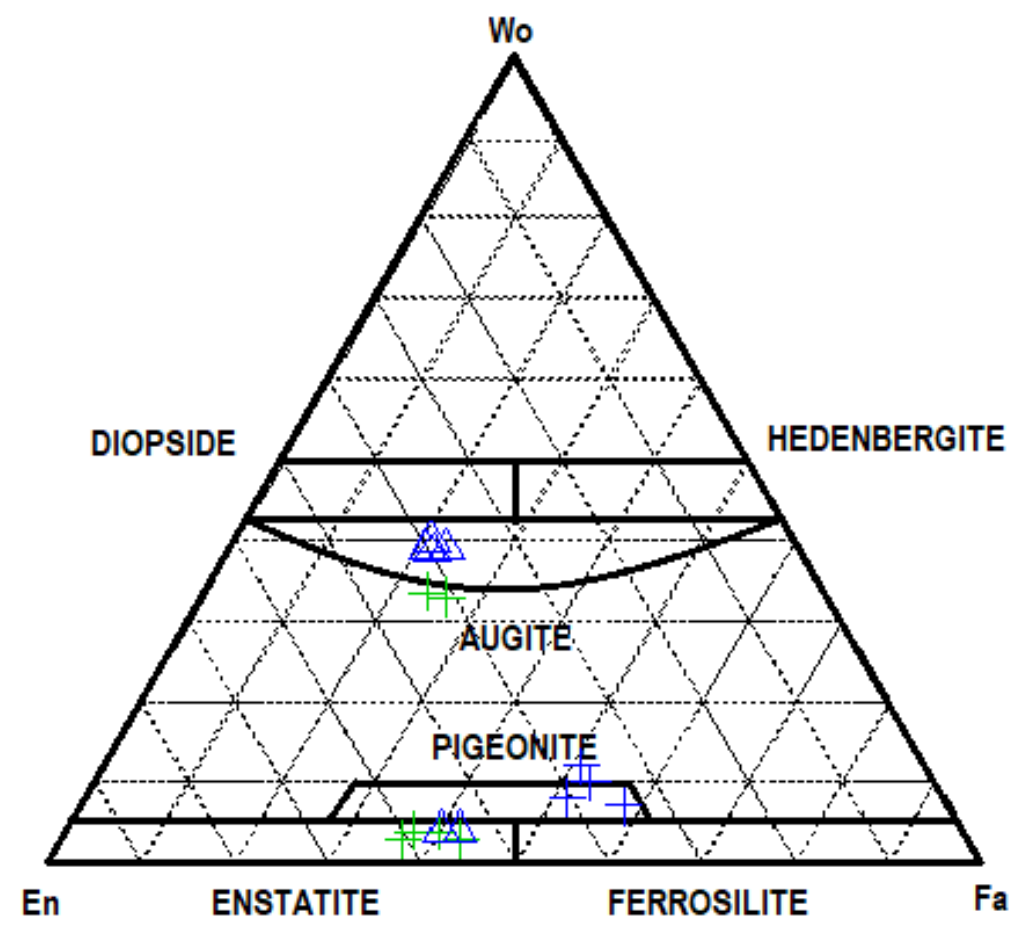

Figure 24. Pyroxenes classification ternary diagram for En: Wo: Fa phases. Green crosses for EPMA data for pyroxene crystals of 2011 dtccl11 sample. Blue Triangles (pumice) and Crosses (lava) data from Castro et al. (2013).

\subsubsection{Oxides}

Magnetite and ilmenite crystals are both present in all samples and are relatively abundant. They can be found either as phenocrysts dispersed in the groundmass or inclusions in all other mineral phases. The shape of the grains varies, but for the most part grains are subhedral to anhedral and sometimes shows signs of re-equilibration with dissolved borders. Geochemically speaking, the magnetite crystals show a high percentage of $\mathrm{TiO}_{2}$ with a total range of 19.89$17.26 \mathrm{wt} \%$, the values are lower in average than the 1960 event. (Table 3 of the appendix) 

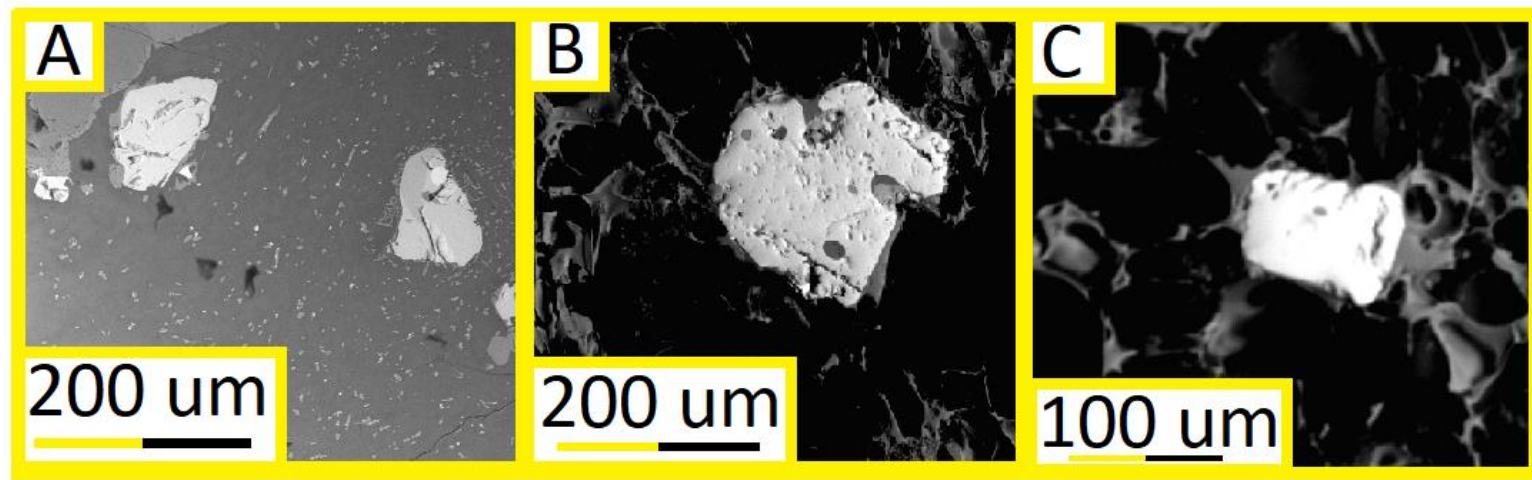

Figure 25. Oxide pair for 2011 eruptive event. A) adjacent pair dtccl-Ex. B) and C) pumice oxide pair Pmh11-H.

\subsubsection{Temperature and Oxygen Fugacity}

The calculations for this unit (Table 9), show that the total average is approximately $890^{\circ} \mathrm{C}$. The higher value belongs to the lava sample; since Castro's measurements are mostly pumice, the calculations are closer to the measured pumice sample. Regarding oxygen fugacity, the values show little variation with an average of -0.83 making them the most negative out of all three events.

\begin{tabular}{|c|c|c|c|}
\hline Sample & Texture group & $\mathrm{Ti}-\mathrm{Fe} \mathrm{T}^{\circ} \mathrm{C}$ (average) & Ox fug \\
\hline Dtccl11 & TG3 & 901 & -0.82 \\
\hline Pmh & TG5 & 875 & -0.81 \\
\hline Castro (2013) & - & 892 & -0.87 \\
\hline & Total average & 889 & -0.83 \\
\hline
\end{tabular}




\subsubsection{Water Content}

The new sample measurements in the present study are compared to CC measurements from Castro et al. (2013) taken from Waters and Lange (2015), (Table 10). The results show a clear dependence of water content on temperature as can be seen by the range of values obtained from the highest 4.99 and the lowest being 2.53 , meaning a $2.43 \mathrm{w} \%$ difference accounting for a $50{ }^{\circ} \mathrm{C}$ change.

\begin{tabular}{|c|c|c|c|}
\hline \multicolumn{4}{|c|}{$\begin{array}{l}\text { Table 10. Waters and Lange (2015) hygrometry average results per sample for } 2011 \\
\text { eruptive event compared with samples from the present study. }\end{array}$} \\
\hline Sample & Temperature & $\begin{array}{l}\text { Average } \mathrm{H}_{2} \mathrm{O} \\
\text { wt\% phenocrysts }\end{array}$ & $\begin{array}{l}\text { Average } \mathrm{H}_{2} \mathrm{O} \text { wt } \% \\
\text { Microlites }\end{array}$ \\
\hline Dtccl11 & 903 & 3.43 & 3.22 \\
\hline PMH & 875 & 3.93 & - \\
\hline Puy 10 & 925 & 2.53 & - \\
\hline Puy 15 & 875 & 3.29 & - \\
\hline Puy 17 & 825 & 4.99 & - \\
\hline Puy 2 & 850 & 3.92 & - \\
\hline \multirow[t]{2}{*}{ Puy 9} & 900 & 2.59 & - \\
\hline & Total Average & 3.53 & - \\
\hline
\end{tabular}




\section{Discussion}

\subsection{Temperature and water content comparison across events}

The temperature average for the 1960 and 1921 eruptions is very similar, around $950^{\circ} \mathrm{C}$, which is quite hot for rhyolitic melts that are close to surface. The lower temperature measured for the 2011 eruption of $890^{\circ} \mathrm{C}$ is in line with Castro's (2013) measurements for the 2011 eruptive event. As a consequence, for this difference in temperature, calculated water contents also change in the same manner, with the 2011 event having the highest wt\% of 3.53 while the 1921 and 1960 events have similar values of 2.57 and $2.67 \mathrm{wt} \%$ respectively. This relation stands out by plotting the average water content vs average temperature for each sample. (Fig. 26) 


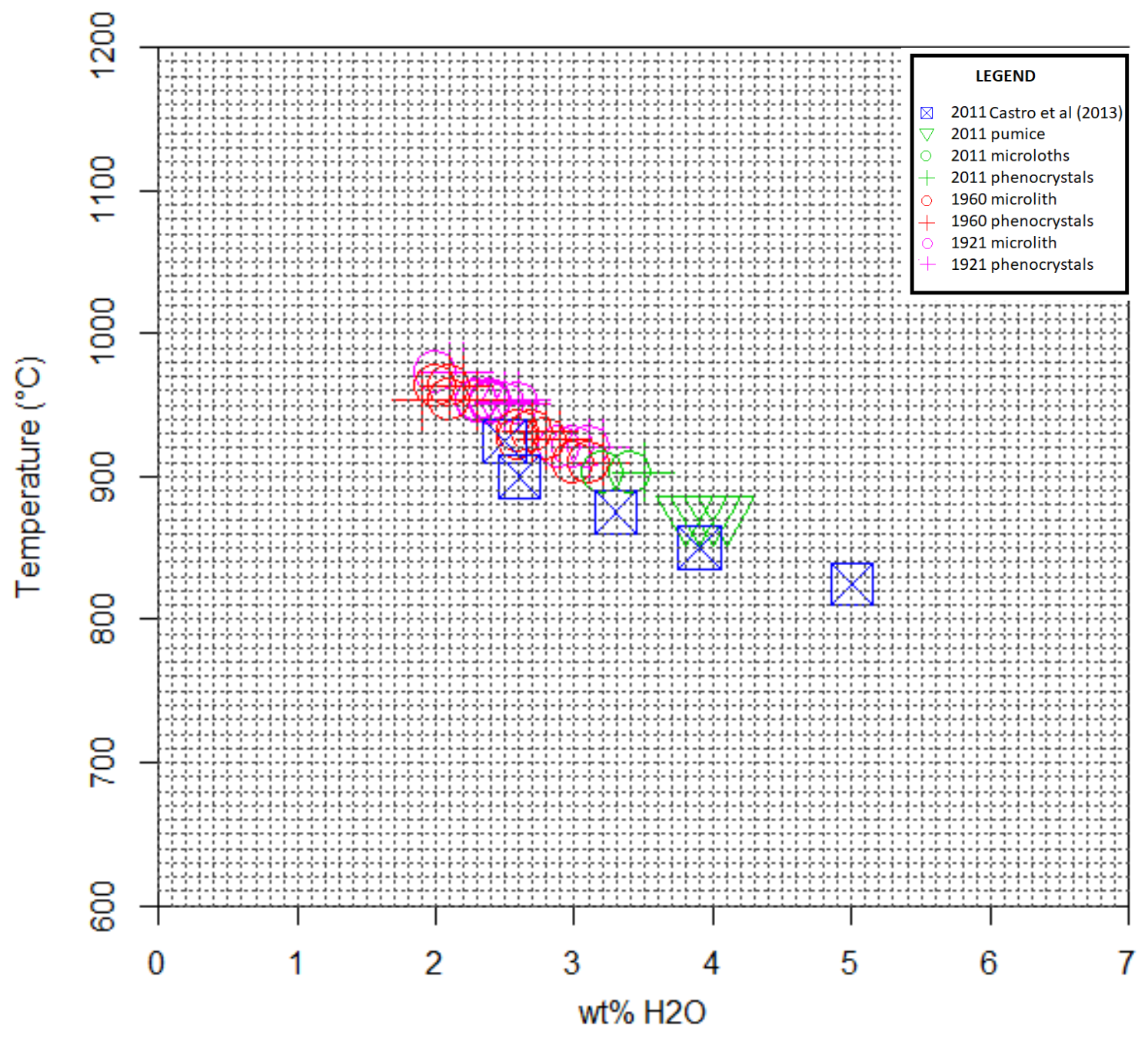

Figure 26. Average measurements per sample of Ghiorso an Evans (2008) temperature vs Water wt\% from Waters and Lange (2015). The size of the symbols represents the error for each method. 
It is well-known that the solubility of water in magmas has an inverse relation to temperature at a given pressure (Lavallée et al., 2015; Yamashita., 1999; Moore et al., 1995). However, this explanation alone does not seem to be reasonable for the chamber conditions of $\mathrm{CC}$, since the water content of a magma will not necessarily rise as it cools neither will it decrease due to addition of a deeper heat source, until decompression takes place. This consideration brings into question whether the only thing that is controlling these variables is the temperature estimation, since the differences in the temperature versus water content correlation does not seem to influence the resulting Anorthite content for all the historic eruptive events of the current study. This can be tested by calculating the water content in different temperature scenarios (Fig. 27) and comparing it to the measured Anorthite content from each sample. These scenarios are:

A. The already explored average temperature per sample.

B. Maintaining the average temperature as a constant, assuming a single magma chamber as a common source, representing the overall storage reservoir temperature for all events

C. Taking the highest measured temperature for each event, meaning that it represents the closest temperature for storage conditions, with the consideration that some variations may be possible within different events.

D. The average temperature for each event, reducing possible variations within chamber conditions. 


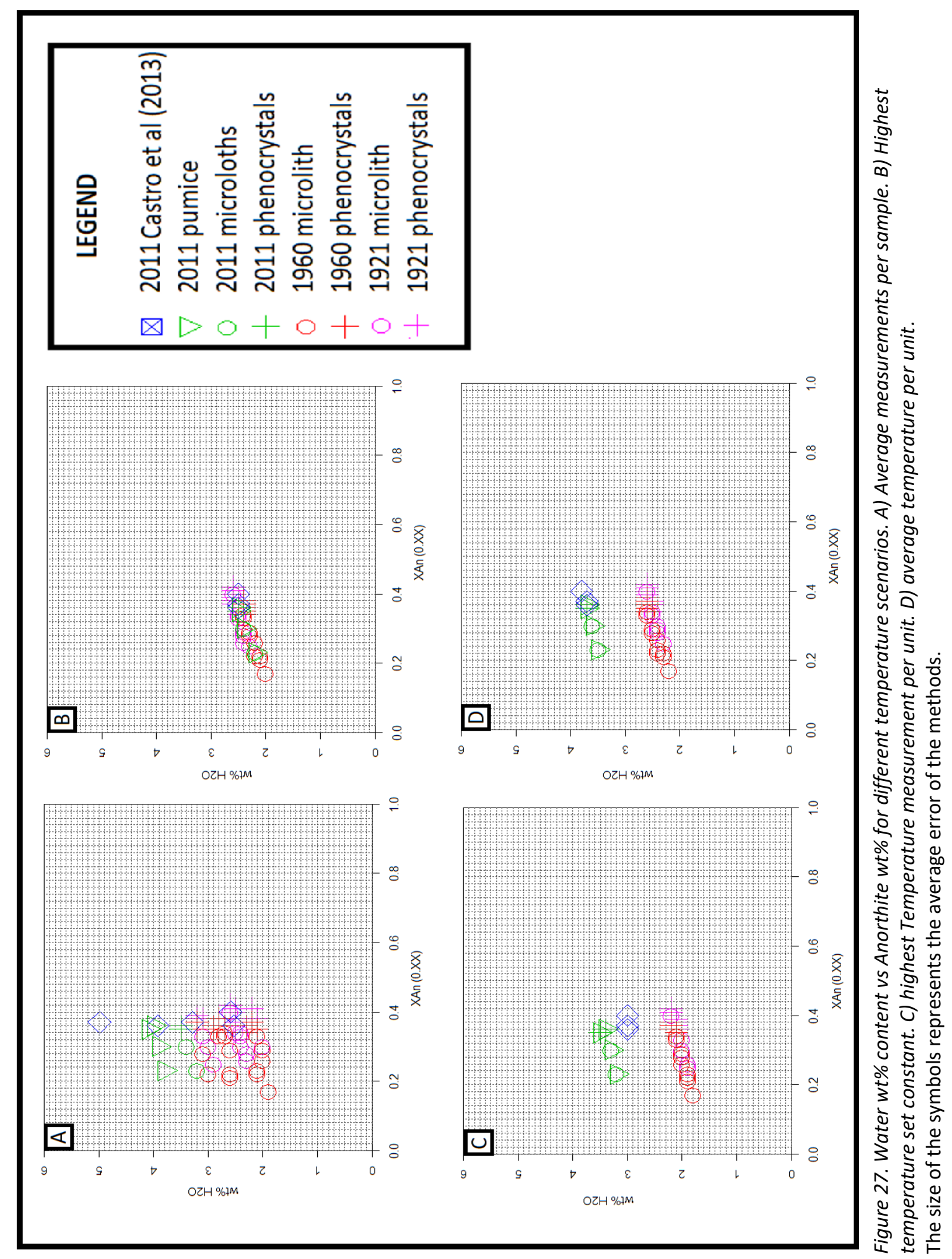


If we observe the scenario "B", minimizing the influence of temperature, a range of $0.2 \mathrm{wt} \%$ of anorthite produces a range of dissolved water content of 0.6 wt\%. However, observing scenario "A", which has the highest temperature variations, accounts for a total range of $3 \mathrm{wt} \%$ of water content variation, which is very significant. It is evident that the temperature becomes very relevant in calculating the water content in the hygrometer model, when 20 degrees variation can lead up to a $0.5 \mathrm{wt} \%$ change in the water content (Waters and Lange, 2015) and the 20 degrees variation is also the standard error for Ghiorso and Evans TiFe thermometer, so any slight deviation from any measurement can have a big impact on the estimated water content.

Considering scenario " $\mathrm{C}$ " does not seem an unreasonable case, and the results are similar to that of scenario "D". However, given the variation of temperatures measured on the rock samples, the result could be influenced by presence of oxide pairs that equilibrated under different temperature conditions; higher temperatures could lead to an underestimation of the water content. To avoid misinterpretations the scenario " $\mathrm{D}$ " seems to be a reasonable method to apply, but it still is a reference value more than an absolute.

The other fact that stands out is that the 2011 eruption event is different than the 1960 and 1921 events, and even if there are some high temperature measurements that result in low water concentrations, the average trend is that the pre-eruptive variables do have higher dissolved water content and lower temperature, as can be observed in Scenario "C" and "D". This fact can also be backed up by the work of Alloway et al. (2015) which proposes different 
intermediate chambers as the source for the volcanic products of the 2011 event. In addition, the vents for the 2011 event are not part of the same fissure system as the other two historic eruptions, therefore it is possible that the pre-eruptive variables could vary.

Finally, even if the average temperature for the 1960 and 1921 lavas are closely equivalent there is an important variation among samples from each event, which is that the measurements on cluster grains give temperature values of up to $100{ }^{\circ} \mathrm{C}$ higher than the measurement for phenocrysts. One interpretation could be that there is, in fact, some variations of temperature within the magma chamber, which could be due to input of hotter magma in the deepest parts of the chamber causing a zonation of different temperature magma batches.

\subsection{Textural analysis in variable changes}

The five texture groups, described in the method section, are weighed against the pre eruptive variables for magmatic chamber conditions (Fig. 28). The results show no systematic correlation between the different textures and a particular variable. Since vesicles are the main difference in the textural separation of the groups, it can be concluded that the formation of vesicles does not respond to within chamber characteristics of the magma but rather to the dynamic process during the ascent and/or flow, changing brittle and ductile conditions (Schipper et al., 2013). The temperature is very stable across all the texture groups, where the lower peaks have to do with the fact that 2011 eruption has on average lower temperature measurements. Water content is a similar case, but opposite to temperature since the hygrometer model calculates lower water content for higher 


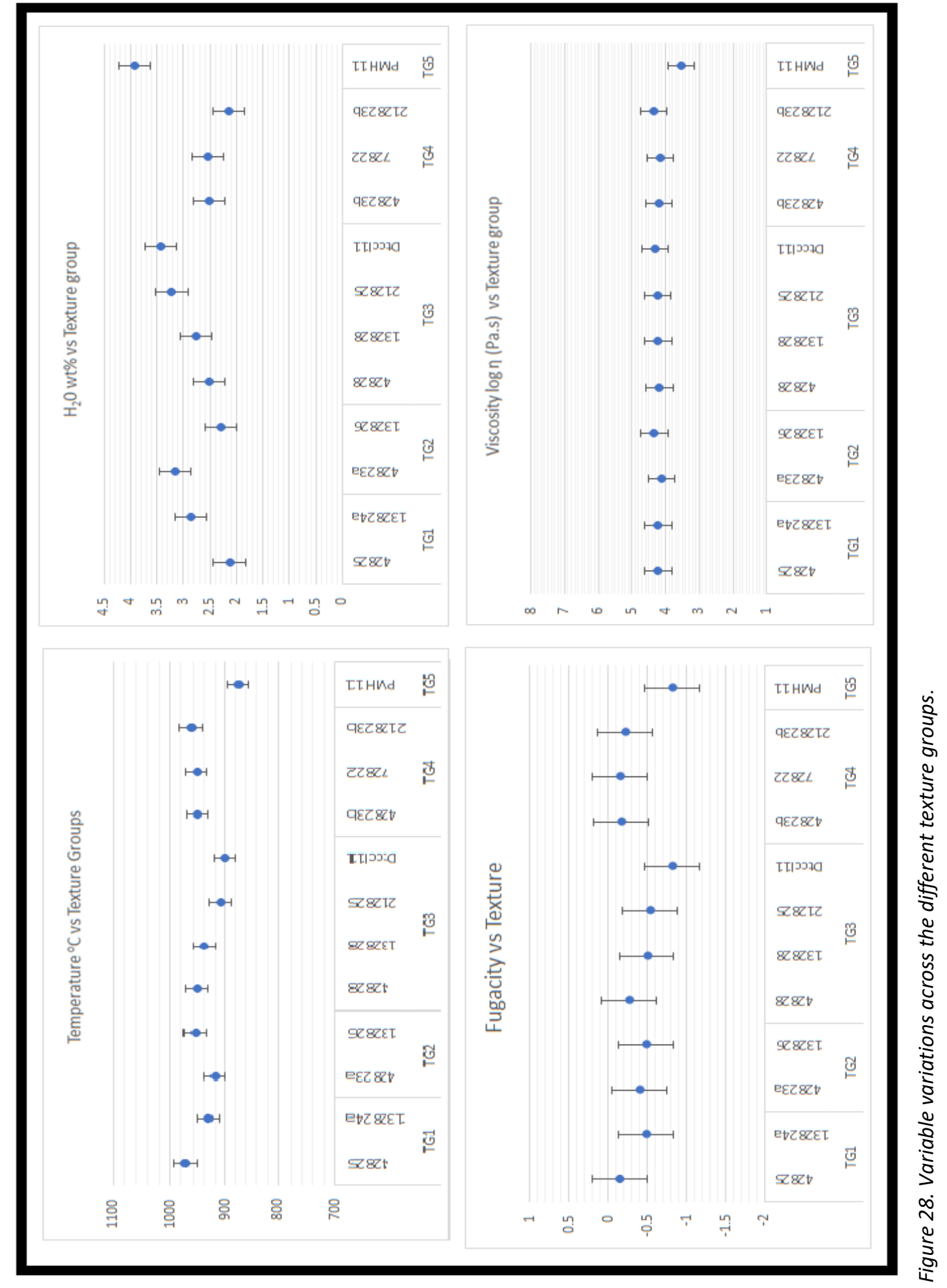


temperature values. Viscosity is almost identical in all rock samples. Finally, the oxygen fugacity is the most fluctuating variable and is very weakly correlated to rock textures.

To explain the latter variation, one possibility could be that the degassing of magma causes alterations in the oxygen fugacity but there is no evidence that supports this case. In fact, the opposite is known to be true where the fugacity values measured for the NNO buffer, with ilmenites and magnetite's, show little alteration from $\mathrm{H}_{2} \mathrm{O}$ degassing, therefore different fugacity values could be attributed to the source material (Waters and Lange, 2015). Whether this is reflected in the composition of the oxide pairs is still unclear.

The variation in TG4 (obsidian samples that are almost devoid of vesicles) is minimal compared to the other groups displaying similar trends for all the measured variables. It has higher fugacity values and lower water content so these conditions could point to post volcanic processes, but in order to confirm more samples would be needed.

\subsection{Viscosities}

Evaluating all the scenarios of temperature vs water content scenarios, the conclusion is that the most likely to produce the most accurate result is the average temperature per eruptive event, therefore these results are used in the Giordano (2008) model, for pre eruptive viscosities, and the measured $\mathrm{H}_{2} \mathrm{O}$ content from geochemical data is used to calculate post eruption viscosity of degassed lavas (Table 11). 
The obtained values show that the viscosity of pre-eruptive magma is quite low for a rhyolitic phenocryst-poor melt, which usually ranges from 5-6 log $\eta(\mathrm{Pa} \mathrm{s})$ (Takeuchi 2011) and that all three events have flows of almost equal pre-eruptive viscosity values. The 2011 event has slightly higher viscosities, but this could be attributed to normal error of the model which is $0.45 \log$ units (Giordano 2008).

\begin{tabular}{|l|c|c|c|c|c|}
\hline $\begin{array}{l}\text { Table 11. Giordano } \\
\text { (2008) viscosity } \\
\text { calculations for CC } \\
\text { historic eruptive } \\
\text { events }\end{array}$ & \multicolumn{2}{|c|}{ Pre eruptive } & \multicolumn{2}{|c|}{ Post eruptive } & \\
\cline { 2 - 5 } & $\mathrm{T}\left({ }^{\circ} \mathrm{C}\right)$ & $\log \eta(\mathrm{Pa} \mathrm{s})$ & $\mathrm{T}\left({ }^{\circ} \mathrm{C}\right)$ & $\log \eta(\mathrm{Pa}$ s) & \multirow{2}{*}{ Event } \\
\hline Min temp. & 920 & 4.42 & 920 & 6.90 & \\
Average temp. & 950 & 4.17 & 950 & 6.52 & \multirow{2}{*}{1921} \\
Max temp. & 973 & 3.98 & 973 & 6.24 & \\
\hline Min temp. & 909 & 4.52 & 909 & 7.15 & \\
Average temp. & 940 & 4.26 & 940 & 6.75 & 1960 \\
Max temp. & 963 & 4.07 & 963 & 6.46 & \\
\hline Min temp. & 875 & 4.49 & 875 & 7.47 & \\
Average temp. & 890 & 4.36 & 890 & 7.27 & 2011 \\
Max temp. & 901 & 4.27 & 925 & 6.83 & \\
\hline
\end{tabular}

The observed difference for pre-eruptive viscosities compared to the post eruptive measurement of degassed lava rocks is $2.35,2.49$ and 2.9 log units for 1921, 1960 and 2011 respectively signaling similar degassing conditions for all three events (Fig. 29), and quite possibly explaining why the 1921 and 1960 eruptions were so similar. It does not explain the reason for 2011 event's more elevated VEI and overall eruption mechanics therefore this must be related to dynamic processes due to external controls. 


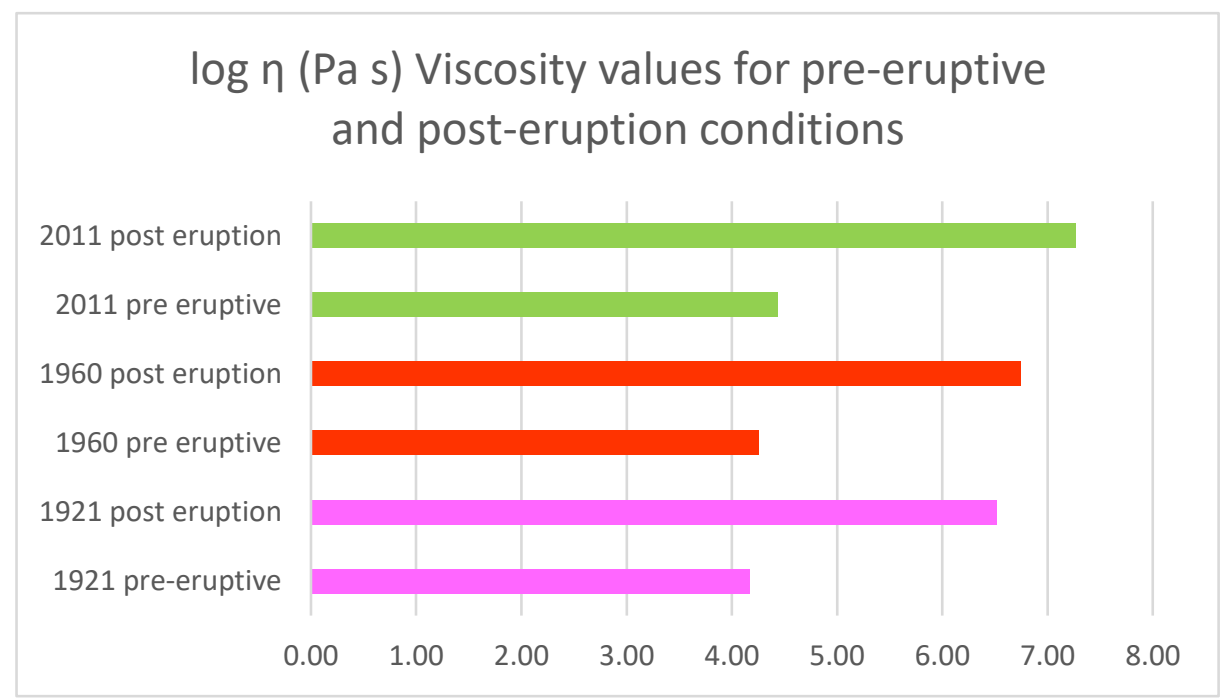

Figure 29. Histogram of pre-eruptive viscosity vs degassed post eruptive lava sample viscosities for all three CC historic eruptions.

\subsection{Equilibrium of Plagioclase phenocrysts}

There is an intensive degassing regime for all three events, which have approximately $94 \%$ of the water content loss occurring during the explosive to effusive transition. Since degassing en-route to the surface can cause crystallization of plagioclase of a wide range of compositions and even produce phenocryst-sized crystals (Waters et al., 2015), one of the questions to be answered is whether this is the case for the $\mathrm{CC}$ historic events and if reequilibration of the plagioclase happened. If this were the case, the calculations for water content taken from the hygrometer could be inaccurate since the feldspars would not have equilibrated at magma storage conditions but rather during ascent and vigorous degassing. One condition of degassing crystallization is that nucleation of plagioclase ceases, leading to a low concentration of plagioclase phenocrysts and microlites (Waters et al., 2015). The samples analyzed in the present study have low phenocryst content, but the plagioclase is 
relatively abundant and different sizes suggest a high level of nucleation. This supports the concept that equilibration happened in a chamber before eruption (Tables 26, 27 and 29 of the appendix) and that plagioclase compositions reflect re-eruptive conditions.

\subsection{Explosive to Effusive Behavior}

The explanation of the complexity of the hybrid eruption of the 2011 CC eruption proposed by Schipper et al. (2013) is the interplay of both ductile and brittle processes developing permeability as a mechanism to achieve the longlived, open-system, degassing regime. Another proposed explanation is that different deep magma influxes occur at different periods of time during the event where the complex structural-controlled plumbing system plays a major role (Alloway et al., 2015, Jay et al., 2014). In general, the transition between explosive to effusive behavior can be explained by two different phenomena. The first is that shallower volatile-rich magma is the first to erupt and taps into parts of the chamber that are have less dissolved water causing an effusive phase. The other explanation would be related to changes in the degassing regime, as due to modifications to the permeability of the ascending magma through the conduit (Cassidy et al., 2018). In the present study, we can discard the first possibility since there is no difference in the dissolved pre-eruptive water content though all rock textures, even pumice, consequently the second scenario is the more reasonable explanation for all three events. 


\subsection{Magma ascent and possible volcanic triggers}

All three historic eruptive events have similar characteristics. They all started with a vigorous explosive stage and eventually moved on to effusive style, with some level of cyclic activity of explosive to effusive following the initial event. The 2011 event has the highest VEI reaching a level of 5, and 1921 and 1960 have VEI of 3 to 4 . However, all the pre-eruptive variables are extremely close between the three events the compositions are almost identical, the measured temperature is the practically the same for the 1921 and 1960 events, and slightly higher than the 2011. Since these two variables are the same, the measured water content is also very stable. So, given all the similarities one must think that the precursors of the events must be the same as well. It is known that the 1960 eruptive event followed a massive earthquake that happened just 38 hours before the explosive activity begun. This is one of the rare cases where the link between eruption and tectonic movement is clearly observable, so the 1960 earthquake is widely considered a trigger for the eruption. The problem is that neither the 2011 nor the 1921 event have direct evidence of an earthquake triggering the event. So other triggers must also be considered.

Other possible alternative triggers could be either some heat source addition to the magmatic chamber or some mixture of magmas that would cause a destabilization of the long-term chamber contents. The petrological analysis practically discounts any kind of magma mixing, because the bulk geochemical composition of the lavas and the mineral phases are very homogeneous; even the 
textural characteristics are practically the same from event to event. If magma mixing occurred, it is constrained to be in a deeper chamber rather than reflecting the condition of the shallow magmatic body. As for an addition of heat that could mobilize the magma, there are studies that suggest a basaltic influence deep within the magmatic system, evidenced in the presence of one mineral cluster with olivine and Anorthite rich plagioclase (Jay et al., 2014). In the present study, no mafic xenolith was found, but there is a strong presence of mineral clusters with a high concentration of mafic minerals (Cpx, Opx). The temperatures calculated on oxide pair inclusions in these clusters, result in temperatures up to 100 degrees higher than those free in the groundmass. With all that said, heating in the bottom of the chamber due to an influx of basaltic magma cannot be discounted, but the most likely scenario is that the regional tectonic setting influences some control on the structures in the complex plumbing system of the hosting rocks that could lead to different parts of the chamber experiencing different degassing and decompression regimes in different time periods.

\subsection{Comparing $\mathrm{CC}$ historic eruption to other rhyolitic explosive events}

Since all three historic eruptive events have similar pre-eruptive variables it is useful to compare their composition, temperature and water content to other eruptive events to see if there is actual difference in the eruptive style related to the differences in variables. Two suites are chosen for this comparison: A) Mt. Pelée volcano, B) Soufrière Hills volcano. 
A) Mt.Pelée volcano has some similar characteristics to CC since both have an effusive and explosive phase, in this case surge-Plinian and Plinian to dome, geochemically speaking the overall composition is andesitic but have some rhyolitic glass (Martel 2012), however, water content is slightly higher and temperature is slightly lower (Fig. 30). One distinct characteristic is the evidence of magma mixing that occurs in the chamber (Martel et al., 2006).

B) Soufrière Hills is also characterized by Plinian events that had a dome forming stage. The rock composition is andesitic, and the pre-eruptive variables are quite similar to that of CC in water measurements and temperatures (Fig. 30). However, the driving force for eruption of this volcano was the rapid exsolution of volatiles, causing overpressure in the chamber and causing a dramatic increase in the viscosity (Sparks and Melnik, 1999).

Evaluating the pre eruptive variables (Fig. 30), it can be observed that each of the three volcanoes have different trends and individual variations do not correlate in the same way. For example, in Fig. 30a, there is a negative correlation of water to anorthite content at Soufrière Hills, and in Fig. 30b the temperature for Mt. Pelée does not show a strong negative correlation between water content and temperature. In both volcanos the most changing variable is the Anorthite content, which is constant for CC. Further analysis is needed comparing to a wider set of volcanic data, to reach a conclusion on pre-eruptive variable trends. 


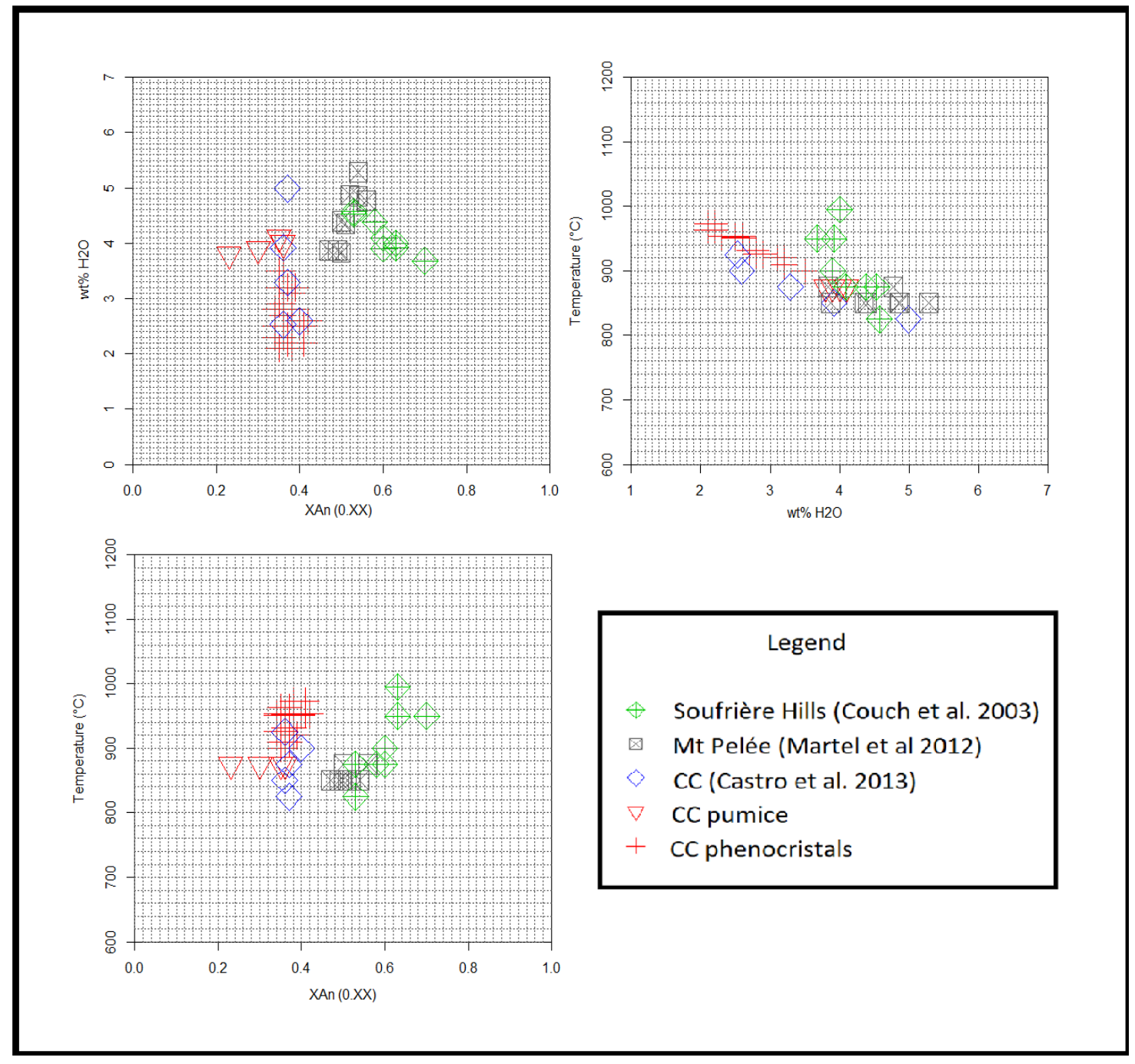

Figure 30. Pre-eruptive variable comparison for different volcanic events. 


\section{Conclusions}

Based on this examination of the pre-eruptive variables in lavas from the 1921, 1960 and 2011 eruptions of the Cordon Caulle volcanic complex, the following conclusions can be drawn:

1) The pre eruptive variables from all three events are extremely similar, the average temperature calculations for 1921 is $950^{\circ} \mathrm{C}$ while the 1960 event has 940 degrees and the average water content is $2.57 \mathrm{wt} \%$ for 1921 and $2.67 \mathrm{wt} \%$ for 1960. The 2011 event shows a slight difference with lower temperature average $900{ }^{\circ} \mathrm{C}$, and higher water content of $3.53 \mathrm{wt} \%$. Overall, the composition of all mineral phases is homogeneous with slight variations in overall volume and stability of some phases. This suggests a common source chamber for all three

events, as also suggested by Gerlach et al., (1988) and Jay et al. (2014). The common source could be an intermediate reservoir where magma would rest until the conditions arise to mobilize the melt, either straight to surface, or to other shallow bodies. This could result in further changes to some physical conditions, such as the slight difference in temperature and water content resulting in the explosivity index for the 2011 event.

2) The difference in the calculated water content from the hygrometer model and the water content measured directly on the samples suggests that a strong degassing phase occurred before the effusive batch reached the surface. However, there is no evidence to suggest that degassing induced crystallization of plagioclase occurred. 
3) There is a strong variation in the pre-eruptive water content compared to that of the extruded rock and this leads to a 2-3 log $\eta$ (Pals) unit difference between preeruptive viscosity and the viscosity of the lava that has already degassed. Whether this behavior is connected to the different observed textures is still unclear and further analysis of the vesicles is needed to clarify this point.

4) Even though the volcanic trigger for the 1960 volcanic event is presumed to be the 1960 magnitude 9.5 Chilean earthquake, the minimal textural difference between all three historic events does not seem to suggest different triggers were involved. Instead, a strong structural control for the mobilization of magma to the surface is implicated, together with possible mobilization by intrusion of hot magma at depth.

5) The pre-eruptive variables as calculated from mathematical models are extremely dependent on the precision of instruments. Therefore, is recommended to obtain said values for as many different techniques as possible for each value, for example, testing with several different models.

\section{Future Research}

A lot of ground has been covered regarding obtaining physical information on specific volcanic centers. Cordon Caulle is no exception, however the complexity of the system makes it hard to obtain strong and unquestionable facts about mechanics of the eruptive event. One point to expand is the water content variable. Even though the Waters and Lange (2015) hygrometer seems to be a reliable method to obtain an estimated weight percentage, it's still unclear how the 
post volcanic processes affect the equilibrium of the mineral phases. A interesting advancement in this regard, would be to compare the obtained water content with other methods. For example, melt inclusions in plagioclase grains were used in Castro et al. (2013). In that study, however, the results showed that the inclusions leaked making the results unreliable. Another, explanation could be that they crystalized under considerably lower quantities of water, therefore a good solution would be to directly measure the water content on the glass with FTIR, and on obsidian flow rocks and pumice samples and compare to the hygrometer calculations. This could help decipher the dynamic processes of the degassing of the magma.

Acquiring more oxide pairs and plagioclase EPMA data from a wider sample selection and a more focused characterization of textural variations, for example, on cluster pairs, or on certain mineral phases, could help decipher if there is a temperature zonation in the magmatic chamber producing variance in the pre eruptive variables.

Another question to be answered would be whether the pre- or posteruptive variables have an important influence on the development of the textural characteristics of the different rocks extruded from the same stage. It seems that they do not for the samples measured in the present study, however some textural groups have 1 or 2 samples per event, so it would be necessary to acquire a wider range of measurements per texture group.

Oxygen fugacity variations between the rock samples of each event could suggest a post volcanic process, for example rocks that possess microlites that 
crystalized under degassing conditions tend to have lower fugacity measurements on the iron-titanium oxide thermometer (Blundy and Cashman, 2008). A more detailed analysis of plagioclase crystals is needed to clarify this point.

Since the three last eruptive events of this volcanic center have almost identical conditions is interesting to note that this was not always the case, as can be observed in the geochemical composition of the rocks before the historic events. Older units of $C C$ are very similar in texture and bulk composition to the historic events, however, there is no ilmenite phase anywhere to be found in these samples, therefore a good line of investigation would be an analysis of the preeruptive variables for these older units using other models, for example twopyroxene thermometry, and for fugacity using the FeTMM oxybarometer proposed in Arato and Audeat (2017).

Finally, pyroxene stability and overall volume contents seem to be very variable within each event. A focused study on pyroxene phenocrysts and cluster grains can lead to understand possible influence of basaltic intrusion in the magmatic chamber. 


\section{References}

Alloway, B. V., Pearce, N. J. G., Villarosa, G., Outes, V. \& Moreno, P. I. (2015). Multiple melt bodies fed the AD 2011 eruption of Puyehue-Cordón Caulle, Chile. Scientific Reports. Nature Publishing Group 5, 1-8.

Arató, R. \& Audétat, A. (2017). FeTiMM - A new oxybarometer for mafic to felsic magmas. Geochemical Perspectives Letters 5, 19-23.

Bacon, C. R. \& Hirschmann, M. M. (1988). Mg/Mn partitioning as a test for equilibrium between coexisting Fe-Ti oxides. American Mineralogist 73, 57-61.

Blundy, J. \& Cashman, K. (2008). Petrologic Reconstruction of Magmatic System Variables and Processes. Reviews in Mineralogy and Geochemistry 69, 179-239.

Campos, A., Moreno, H., Muñoz, J., Antinao, J., Clayton, J, Martin, M. 1998. Área de Futrono-Lago Ranco. Servicio Nacional de Geología y Minería, Mapas Geológicos No. 8, 1 map

Clavero, J., Moreno, H. 1994. Ignimbritas Licán y Pucón: Evidencias de erupciones explosivas andesítico-basálticas postglaciales del volcán Villarrica, Andes del Sur, 39²5'S. In Congreso Geológico Chileno, No. 7, Actas. 1, 250-254.

Cassidy, M., Manga, M., Cashman, K. \& Bachmann, O. (2018). Controls on explosiveeffusive volcanic eruption styles. Nature Communications 9 Article number: 2839.

Castro, J. M., Schipper, C. I., Mueller, S. P., Militzer, A. S., Amigo, A., Parejas, C. S. \& Jacob, D. (2013). Storage and eruption of near-liquidus rhyolite magma at Cordón Caulle, Chile. Bulletin of Volcanology 75, 1-17.

Cembrano, J.; Hervé, F.; Lavenu, A. 1996. The Liquiñe-Ofqui fault zone: a long-lived intra-arc fault system in southern Chile. Tectonophysics 259, 55-66.

Cembrano, J. \& Lara, L. (2009). The link between volcanism and tectonics in the southern volcanic zone of the Chilean Andes: A review. Tectonophysics 471, 96113.

Couch, S. (2003). Experimental Constraints on the Conditions of Formation of Highly Calcic Plagioclase Microlites at the Soufrire Hills Volcano, Montserrat. Journal of Petrology 44, 1455-1475.

Gerlach, D.C., Frey, F.A., Moreno-Roa, H., and Lopez Escobar, L., 1988, Recent volcanism in the Puyehue Cordón Caulle region, southern Andes, Chile $\left(40.5^{\circ} \mathrm{S}\right)$ : Petrogenesis of evolved lavas: Journal of Petrology 29, 333-382.

Ghiorso, M. S. \& Evans, B. W. (2008). Thermodynamics of rhombohedral oxide solid solutions and a revision of the Fe-Ti two-oxide geothermometer and oxygenbarometer. American Journal of Science 308, 957-1039.

Hammond PA, Taylor LA (1982) The ilmenite titano-magnetite assemblage - kinetics of reequilibration. Earth Planet Sci Lett 61, 143-150. 
Hickey, R., Frey, F.A., Gerlach, D.C., and Lopez-Escobar, L., 1986, Multiple sources for basaltic arc rocks from the Southern Volcanic Zone of the Andes (34-41 ${ }^{\circ}$ ): Trace element and isotopic evidence for contributions from subducted oceanic crust, mantle, and continental crust: Journal of Geophysical Research 91, 5963-5983.

Giordano, D., Russell, J. K. \& Dingwell, D. B. (2008). Viscosity of magmatic liquids: A model. Earth and Planetary Science Letters 271, 123-134.

Hervé, F., 1994. The Southern Andes between $39^{\circ}$ and $44^{\circ} S$ latitude: the geological signature of a transpressive tectonic regime related to magmatic arc. Tectonics of the Southern Central Andes. Springer Verlag, pp. 243-248.

Janoušek, V., Farrow, C. M. \& Erban, V. (2006). Interpretation of whole-rock geochemical data in igneous geochemistry: Introducing Geochem

Jay, J., Costa, F., Pritchard, M., Lara, L., Singer, B. \& Herrin, J. (2014). Erratum to "Locating magma reservoirs using InSAR and petrology before and during the 2011-2012 Cordón Caulle silicic eruption”. Earth Planet. Sci. Lett 395, 254-266.

Lange, R. A., Frey, H. M. \& Hector, J. (2009). A thermodynamic model for the plagioclase-liquid hygrometer/thermometer. American Mineralogist 94, 494-506.

Lara, L.E., Moreno-Roa, H., and Naranjo, J.A., 2004, Rhyo-dacitic fissure eruption in Southern Andes (Cordón Caulle; 40.5ㅇ) after the 1960 (Mw:9.5) Chilean earthquake: A structural interpretation: Journal of Volcanology and Geothermal Research 138, 127-138.

Lara, L. E., Lavenu, A., Cembrano, J. \& Rodríguez, C. (2006a). Structural controls of volcanism in transversal chains: Resheared faults and neotectonics in the Cordon Caulle-Puyehue area (40.5 ㅇ), Southern Andes. Journal of Volcanology and Geothermal Research 158, 70-86.

Lara, L. E., Moreno, H., Naranjo, J. A., Matthews, S. \& Perez de Arce, C. (2006b). Magmatic evolution of the Puyehue-Cordon Caulle Volcanic Complex (40S), Southern Andean Volcanic Zone: From shield to unusual rhyolitic fissure volcanism. Journal of Volcanology and Geothermal Research 157, 343-366.

Lavallée, Y. et al. (2015). Thermal vesiculation during volcanic eruptions. Nature 528, 544-547.

Lavenu, A. \& Cembrano, J. (1999). Compressional- and transpressional-stress pattern for Pliocene and Quaternary brittle deformation in fore arc and intra-arc zones (Andes of Central and Southern Chile). Journal of Structural Geology 21, 1669 1691.

Le Bas MJ, Streckeisen AL (1991) The IUGS systematics of igneous rocks. J Geol Soc Lond 148:825-833.

Lopez-Escobar, L., Cembrano, J. \& Moreno, H. (1995). Geochemistry and tectonics of the Chilean southern Andes basaltic Quaternary volcanism (37-46 ${ }^{\circ}$ S). Revista Geologica de Chile 22, 219-234. 
H. Moreno-Roa, Geología del area volcanica Puyehue-Carrán enlos Andes del sur, Chile, unpublished thesis, Departamento deGeología, Universidad de Chile, 1977

Martel, C. (2012). Eruption dynamics inferred from microlite crystallization experiments: Application to plinian and dome-forming eruptions of Mt. Pelée (martinique, lesser antilles). Journal of Petrology 53, 699-725.

Martel, C., Radadi Ali, A., Poussineau, S., Gourgaud, A. \& Pichavant, M. (2006). Basaltinherited microlites in silicic magmas: evidence from Mt. Pelee (Martinique, F.W.I.). Geology 34,905-908.

McMillan, N.J., Harmon, R.S., Moorbath, S., Lopez-Escobar, L., Strong, D., 1989. Crustalsources involved in continental arc magmatism: a case study of Volcan Mocho-Choshuenco, southern Chile. Geology 17, 1152-1156

Moore, G., Vennemann, T. \& Carmichael, I. S. E. (1995). Solubility of water in magmas to 2 kbar. Geology 23, 1099-1102.

Putirka, K. D. (2008). Thermometers and Barometers for Volcanic Systems. Reviews in Mineralogy and Geochemistry 69, 61-120.

Schipper, C. I., Castro, J. M., Tuffen, H., James, M. R. \& How, P. (2013). Shallow vent architecture during hybrid explosive-effusive activity at Cordón Caulle (Chile, 201112): Evidence from direct observations and pyroclast textures. Journal of Volcanology and Geothermal Research 262, 25-37.

Silva Parejas, C., Lara, L. E., Bertin, D., Amigo, A. \& Orozco, G. (2012). The 2011-2012 eruption of Cordón Caulle volcano (Southern Andes): Evolution, crisis management and current hazards. Geophysical Research Abstracts 14, EGU 2012-9382-2.

Singer, B. S., Jicha, B. R., Harper, M. A., Naranjo, J. A., Lara, L. E. \& Moreno-Roa, H. (2008). Eruptive history, geochronology, and magmatic evolution of the PuyehueCordon Caulle volcanic complex, Chile. Bulletin of the Geological Society of America 120, 599-618.

Sparks, R. S. J. \& Melnik, O. E. (1999). Nonlinear dynamics of lava dome extrusion. Nature 402, 37-41.

Stern, C. R. (2004). Active Andean volcanism: its geologic and tectonic setting. Revista geológica de Chile. Servicio Nacional de Geología y Minería 31, 1-51.

Takeuchi, S. (2011), Pre-eruptive magma viscosity: An important measure of magma eruptibility, J. Geophys. Res., 116, B10201.

Tormey, D.R., Hickey-Vargas, R., Frey, F.A. and López-Escobar, L., (1991). 'Recent lavas from the Andean front ( $33^{\circ}$ to $\left.42^{\circ} \mathrm{S}\right)$ : interpretations of along-arc compositional variations'. Geological Society of America, Special Paper. 265, 5777.

Venezky DY, Rutherford MJ (1999) Petrology and Fe-Ti oxide reequilibration of the 1991 Mount Unzen mixed magma. Journal of Volcanology and Geothermal Research. $89,213-230$ 
Walker, G. P. L., 1973. Explosive volcanic eruptions-a new classification scheme. Geol. Rundsch. 62, 431-446.

Waters, L. E., Andrews, B. J. \& Lange, R. A. (2015). Rapid crystallization of plagioclase phenocrysts in silicic melts during fluid-saturated ascent: Phase equilibrium and decompression experiments. Journal of Petrology 56, 981-1006.

Waters, L. E. \& Lange, R. A. (2015). An updated calibration of the plagioclase-liquid hygrometer-thermometer applicable to basalts through rhyolites. American Mineralogist 100, 2172-2184.

Waters, L. E. \& Lange, R. A. (2016). No effect of $\mathrm{H} 2 \mathrm{O}$ degassing on the oxidation state of magmatic liquids. Earth and Planetary Science Letters. 447, 48-59.

Wilson, T., Stewart, C., Bickerton, H., Baxter, P., Outes, V., Villarosa, G. \& E, R. (2013). Impacts of the June 2011 Puyehue-Cordón Caulle volcanic complex eruption on urban infrastructure, agriculture and public health. GNS Science Report.

Yamashita, S. (1999). Experimental study of the effect of temperature on water solubility in natural rhyolite melt to $100 \mathrm{MPa}$. Journal of Petrology 40, 1497-1507.

http://volcanoes.usgs.gov/Products/Pglossary/vei.html 
APPENDIX 
Table 1. 1921 eruptive event Oxide EMPA data.

\begin{tabular}{|c|c|c|c|c|c|c|c|c|c|c|c|c|c|c|}
\hline & Sample & $\mathrm{SiO} 2$ & $\mathrm{TiO} 2$ & $\mathrm{Al} 2 \mathrm{O} 3$ & $\mathrm{Fe} 2 \mathrm{O} 3$ & V2O3 & $\mathrm{Cr} 2 \mathrm{O} 3$ & $\mathrm{FeO}$ & $\mathrm{MnO}$ & $\mathrm{MgO}$ & $\mathrm{CaO}$ & $\mathrm{ZnO}$ & $\mathrm{NiO}$ & Total \\
\hline \multirow{21}{*}{$\begin{array}{l}\mathrm{m} \\
\mathrm{a} \\
\mathrm{g} \\
\mathrm{n} \\
\mathrm{e} \\
\mathrm{t} \\
\mathrm{i} \\
\mathrm{t} \\
\mathrm{e} \\
\mathrm{s}\end{array}$} & $42825-r 1 x$ & 0.08 & 18.05 & 1.73 & 32.31 & 0.51 & 0.01 & 46.22 & 0.63 & 2.03 & 0.01 & 0.04 & 0.02 & 101.61 \\
\hline & 42825-r3ox & 0.09 & 17.61 & 1.96 & 32.72 & 0.53 & 0.02 & 45.67 & 0.58 & 2.17 & 0.16 & 0.07 & 0.01 & 101.56 \\
\hline & $42825-r 3 x$ & 0.06 & 18.12 & 1.71 & 33.85 & 0.46 & 0.01 & 47.02 & 0.68 & 1.74 & 0.03 & 0.02 & 0.01 & 103.70 \\
\hline & $42823 b-C X$ & 0.09 & 17.96 & 2.08 & 32.05 & 0.47 & 0.02 & 45.84 & 0.71 & 2.23 & 0.03 & 0.03 & 0.02 & 101.51 \\
\hline & $42823 b-C X 3$ & 0.12 & 18.05 & 2.04 & 31.82 & 0.45 & 0.01 & 45.82 & 0.74 & 2.16 & 0.03 & 0.03 & 0.04 & 101.29 \\
\hline & 42823b-EX & 0.13 & 16.48 & 1.99 & 34.10 & 0.47 & 0.00 & 43.95 & 0.81 & 1.71 & 0.03 & 0.02 & 0.04 & 99.68 \\
\hline & $42823 b-G X$ & 0.12 & 16.68 & 1.84 & 34.61 & 0.44 & 0.01 & 44.61 & 0.76 & 1.45 & 0.02 & 0.01 & 0.03 & 100.55 \\
\hline & 42823b-BX & 0.09 & 16.91 & 2.05 & 33.60 & 0.49 & 0.02 & 44.69 & 0.69 & 2.18 & 0.03 & 0.02 & 0.05 & 100.78 \\
\hline & 72822-br1 & 0.09 & 16.57 & 2.07 & 35.17 & 0.58 & 0.01 & 44.77 & 0.69 & 1.56 & 0.09 & 0.07 & 0.00 & 101.67 \\
\hline & 72828-OTE & 0.09 & 17.62 & 1.92 & 33.21 & 0.56 & 0.01 & 45.62 & 0.84 & 1.83 & 0.22 & 0.03 & 0.00 & 101.92 \\
\hline & $72822-r 2 m$ & 0.10 & 17.20 & 2.12 & 35.15 & 0.45 & 0.00 & 45.82 & 0.75 & 1.42 & 0.07 & 0.07 & 0.01 & 103.16 \\
\hline & 72822-r1m & 0.09 & 17.42 & 2.04 & 34.36 & 0.53 & 0.00 & 45.88 & 0.74 & 1.89 & 0.17 & 0.07 & 0.00 & 103.18 \\
\hline & 42823a-EX & 0.08 & 17.54 & 2.28 & 33.25 & 0.49 & 0.00 & 45.64 & 0.73 & 1.66 & 0.01 & 0.05 & 0.02 & 101.72 \\
\hline & 42823a-COX & 0.10 & 16.50 & 2.13 & 36.19 & 0.39 & 0.03 & 45.09 & 0.69 & 1.21 & 0.00 & 0.02 & 0.03 & 102.36 \\
\hline & 42823а-МОТХ & 0.07 & 17.81 & 2.02 & 31.90 & 0.47 & 0.02 & 45.58 & 0.67 & 1.96 & 0.02 & 0.08 & 0.01 & 100.61 \\
\hline & 42823a-RCLX & 0.13 & 17.55 & 1.98 & 33.93 & 0.48 & 0.01 & 46.05 & 0.57 & 1.46 & 0.04 & 0.01 & 0.06 & 102.22 \\
\hline & \begin{tabular}{|l|}
$42828-A X$ \\
\end{tabular} & 0.11 & 18.03 & 1.97 & 32.58 & 0.34 & 0.01 & 46.11 & 0.78 & 1.66 & 0.15 & 0.00 & 0.05 & 101.73 \\
\hline & 42828-BX & 0.12 & 17.20 & 1.89 & 33.91 & 0.40 & 0.03 & 45.31 & 0.68 & 1.35 & 0.03 & 0.01 & 0.03 & 100.94 \\
\hline & 42828-EX & 0.13 & 18.13 & 1.94 & 33.05 & 0.39 & 0.00 & 46.55 & 0.71 & 1.47 & 0.01 & 0.01 & 0.05 & 102.39 \\
\hline & 42828-OTX & 0.12 & 18.08 & 1.65 & 33.04 & 0.37 & 0.00 & 46.39 & 0.78 & 1.52 & 0.02 & 0.01 & 0.03 & 101.97 \\
\hline & 42828-OTS & 0.10 & 18.23 & 1.77 & 31.70 & 0.43 & 0.01 & 46.21 & 0.67 & 1.60 & 0.10 & 0.02 & 0.04 & 100.84 \\
\hline & $42825-r 1 x$ & 0.05 & 47.18 & 0.19 & 6.56 & 0.32 & 0.02 & 41.57 & 0.78 & 2.84 & 0.03 & 0.00 & 0.05 & 99.54 \\
\hline & 42825-r3ox & 2.22 & 45.26 & 0.79 & 11.11 & 0.39 & 0.01 & 36.05 & 0.69 & 3.15 & 0.18 & 0.00 & 0.00 & 99.85 \\
\hline & $42825-r 3 x$ & 0.08 & 48.25 & 0.16 & 6.11 & 0.33 & 0.00 & 42.55 & 0.70 & 2.90 & 0.05 & 0.02 & 0.00 & 101.15 \\
\hline & $42823 b-C X$ & 0.05 & 47.79 & 0.23 & 5.34 & 0.36 & 0.01 & 42.04 & 0.85 & 3.13 & 0.11 & 0.00 & 0.05 & 99.91 \\
\hline & $42823 b-C X 3$ & 0.06 & 46.47 & 0.22 & 7.68 & 0.44 & 0.02 & 40.80 & 0.88 & 3.02 & 0.07 & 0.00 & 0.04 & 99.66 \\
\hline & 42823b-EX & 0.05 & 47.13 & 0.14 & 6.32 & 0.37 & 0.01 & 41.37 & 0.93 & 2.46 & 0.01 & 0.00 & 0.05 & 98.78 \\
\hline 1 & $42823 b-G X$ & 0.11 & 46.23 & 0.17 & 8.27 & 0.46 & 0.00 & 40.29 & 1.07 & 2.41 & 0.05 & 0.00 & 0.05 & 99.07 \\
\hline 1 & 42823b-BX & 0.07 & 46.98 & 0.17 & 6.92 & 0.35 & 0.02 & 41.18 & 0.94 & 2.55 & 0.03 & 0.00 & 0.01 & 99.20 \\
\hline $\mathrm{m}$ & 72822-br1 & 0.03 & 48.17 & 0.22 & 7.29 & 0.42 & 0.03 & 42.38 & 0.88 & 2.60 & 0.02 & 0.06 & 0.01 & 102.09 \\
\hline e & 72822-ОTE & 0.02 & 46.56 & 0.18 & 8.91 & 0.51 & 0.00 & 41.06 & 0.77 & 2.68 & 0.01 & 0.05 & 0.00 & 100.74 \\
\hline $\mathrm{n}$ & $72822-r 2 m$ & 0.06 & 47.69 & 0.22 & 7.08 & 0.30 & 0.00 & 42.04 & 0.74 & 2.27 & 0.04 & 0.04 & 0.00 & 100.49 \\
\hline $\mathrm{i}$ & $72822-r 1 m$ & 0.03 & 46.99 & 0.22 & 7.11 & 0.43 & 0.00 & 41.47 & 0.74 & 2.82 & 0.06 & 0.06 & 0.00 & 99.92 \\
\hline $\mathrm{t}$ & $42823 a-E X$ & 0.05 & 47.07 & 0.17 & 6.97 & 0.54 & 0.01 & 41.51 & 0.74 & 3.08 & 0.10 & 0.00 & 0.03 & 100.24 \\
\hline e & 42823a-COX & 0.04 & 49.06 & 0.15 & 5.67 & 0.47 & 0.01 & 43.07 & 0.98 & 2.15 & 0.06 & 0.02 & 0.01 & 101.69 \\
\hline $\mathrm{s}$ & 42823а-МОТХ & 0.04 & 48.03 & 0.19 & 5.76 & 0.41 & 0.01 & 42.33 & 0.80 & 2.26 & 0.03 & 0.03 & 0.00 & 99.90 \\
\hline & 42823a-RCLX & 0.03 & 48.00 & 0.17 & 6.18 & 0.39 & 0.00 & 42.36 & 0.76 & 2.39 & 0.01 & 0.00 & 0.02 & 100.29 \\
\hline & \begin{tabular}{|l}
$42828-A X$ \\
\end{tabular} & 0.06 & 48.27 & 0.19 & 6.54 & 0.38 & 0.01 & 42.45 & 0.85 & 2.51 & 0.12 & 0.00 & 0.05 & 101.39 \\
\hline & 42828-BX & 0.07 & 47.01 & 0.18 & 8.19 & 0.43 & 0.01 & 41.27 & 0.88 & 1.77 & 0.05 & 0.01 & 0.01 & 99.86 \\
\hline & 42828-EX & 0.07 & 47.68 & 0.14 & 7.27 & 0.35 & 0.01 & 41.91 & 0.85 & 2.21 & 0.07 & 0.01 & 0.03 & 100.57 \\
\hline & 42828-ОTX & 0.09 & 49.08 & 0.12 & 5.02 & 0.27 & 0.01 & 43.12 & 0.86 & 1.59 & 0.04 & 0.02 & 0.03 & 100.22 \\
\hline & 42828-OTS & 0.05 & 48.14 & 0.19 & 6.35 & 0.29 & 0.00 & 42.43 & 0.78 & 2.39 & 0.03 & 0.01 & 0.03 & 100.65 \\
\hline
\end{tabular}


Table 2. 1960 eruptive event oxides EMPA data.

\begin{tabular}{|c|c|c|c|c|c|c|c|c|c|c|c|c|c|c|}
\hline & Sample & $\mathrm{SiO} 2$ & $\mathrm{TiO2}$ & $\mathrm{Al} 2 \mathrm{O} 3$ & $\mathrm{Fe} 2 \mathrm{O} 3$ & V2O3 & Cr2O3 & $\mathrm{FeO}$ & $\mathrm{MnO}$ & $\mathrm{MgO}$ & $\mathrm{CaO}$ & $\mathrm{ZnO}$ & $\mathrm{NiO}$ & Total \\
\hline \multirow{8}{*}{$\begin{array}{c}M \\
a\end{array}$} & 132824a-AX & 0.09 & 17.78 & 1.74 & 33.17 & 0.28 & 0.01 & 45.87 & 0.87 & 1.53 & 0.01 & 0.00 & 0.04 & 101.34 \\
\hline & $132824 a-A X 4$ & 0.12 & 17.10 & 1.70 & 33.83 & 0.36 & 0.00 & 45.03 & 0.73 & 1.54 & 0.04 & 0.03 & 0.03 & 100.47 \\
\hline & $132824 a-C X$ & 0.30 & 17.97 & 1.82 & 31.92 & 0.33 & 0.01 & 45.34 & 0.79 & 1.51 & 0.17 & 0.03 & 0.01 & 100.20 \\
\hline & 132824a-Dx & 0.06 & 18.75 & 1.64 & 31.10 & 0.32 & 0.01 & 46.82 & 0.78 & 1.60 & 0.02 & 0.01 & 0.02 & 101.09 \\
\hline & 132824a-FX & 0.15 & 17.85 & 1.81 & 32.77 & 0.26 & 0.01 & 45.81 & 0.76 & 1.50 & 0.15 & 0.03 & 0.03 & 101.10 \\
\hline & 212823b-Ax & 0.14 & 16.33 & 1.83 & 35.83 & 0.44 & 0.00 & 44.50 & 0.75 & 1.93 & 0.05 & 0.06 & 0.02 & 101.86 \\
\hline & 212823b-DX & 0.08 & 17.88 & 1.91 & 32.52 & 0.38 & 0.01 & 45.81 & 0.82 & 1.99 & 0.03 & 0.05 & 0.02 & 101.48 \\
\hline & 212823b-DX3 & 0.07 & 18.03 & 1.94 & 32.10 & 0.47 & 0.02 & 45.99 & 0.75 & 1.87 & 0.01 & 0.02 & 0.04 & 101.29 \\
\hline $\mathrm{g}$ & 212823b-EX & 0.10 & 17.66 & 1.81 & 33.02 & 0.39 & 0.02 & 45.63 & 0.82 & 1.76 & 0.03 & 0.02 & 0.04 & 101.26 \\
\hline $\mathrm{n}$ & $132828-A X$ & 0.13 & 18.39 & 1.67 & 32.14 & 0.32 & 0.00 & 46.59 & 0.71 & 1.24 & 0.07 & 0.03 & 0.02 & 101.30 \\
\hline e & 132828-CX & 0.11 & 18.32 & 1.79 & 32.40 & 0.38 & 0.00 & 46.54 & 0.79 & 1.23 & 0.06 & 0.04 & 0.02 & 101.66 \\
\hline $\mathrm{t}$ & 132828-R4X & 0.15 & 18.52 & 1.74 & 31.39 & 0.39 & 0.00 & 46.47 & 0.68 & 1.34 & 0.04 & 0.00 & 0.02 & 100.72 \\
\hline $\mathrm{i}$ & 132828-OTX & 0.11 & 18.68 & 1.66 & 31.33 & 0.33 & 0.00 & 46.74 & 0.76 & 1.39 & 0.03 & 0.00 & 0.03 & 101.04 \\
\hline $\mathrm{t}$ & $212825-A X$ & 0.13 & 17.49 & 1.81 & 33.68 & 0.05 & 0.00 & 45.87 & 0.51 & 1.56 & 0.08 & 0.05 & 0.00 & 101.22 \\
\hline e & 212825-BX & 0.09 & 17.72 & 1.69 & 33.89 & 0.05 & 0.00 & 46.42 & 0.55 & 1.55 & 0.02 & 0.07 & 0.00 & 102.04 \\
\hline \multirow[t]{7}{*}{ s } & 212825-EX & 0.10 & 18.38 & 1.77 & 32.72 & 0.05 & 0.00 & 47.08 & 0.52 & 1.72 & 0.02 & 0.05 & 0.00 & 102.41 \\
\hline & 212825-FX & 0.12 & 17.37 & 1.81 & 34.73 & 0.06 & 0.00 & 46.20 & 0.46 & 1.34 & 0.03 & 0.03 & 0.02 & 102.15 \\
\hline & 132826-AX & 0.09 & 19.56 & 1.81 & 28.69 & 0.47 & 0.02 & 47.44 & 0.50 & 1.47 & 0.02 & 0.05 & 0.00 & 100.10 \\
\hline & 132826-BX & 0.11 & 24.52 & 1.40 & 18.83 & 0.33 & 0.03 & 51.91 & 0.48 & 1.51 & 0.04 & 0.05 & 0.00 & 99.20 \\
\hline & 132826-DX & 0.08 & 19.39 & 1.56 & 30.20 & 0.43 & 0.01 & 47.80 & 0.51 & 1.37 & 0.04 & 0.06 & 0.00 & 101.46 \\
\hline & 132826-EX & 0.10 & 18.01 & 1.77 & 32.07 & 0.37 & 0.01 & 46.19 & 0.46 & 1.51 & 0.11 & 0.08 & 0.00 & 100.66 \\
\hline & $132826-\mathrm{FX}$ & 0.11 & 19.25 & 1.50 & 30.37 & 0.45 & 0.02 & 47.57 & 0.53 & 1.41 & 0.01 & 0.08 & 0.00 & 101.30 \\
\hline \multirow{22}{*}{$\begin{array}{c}\mathrm{l} \\
\mathrm{I} \\
\mathrm{m} \\
\mathrm{e} \\
\mathrm{n} \\
\mathrm{i} \\
\mathrm{t} \\
\mathrm{e} \\
\mathrm{s}\end{array}$} & 132824a-AX & 0.03 & 48.58 & 0.15 & 5.44 & 0.39 & 0.01 & 42.65 & 0.99 & 2.23 & 0.01 & 0.01 & 0.05 & 100.49 \\
\hline & $132824 a-A X 4$ & 0.04 & 48.68 & 0.18 & 6.08 & 0.28 & 0.01 & 42.75 & 0.96 & 2.18 & 0.04 & 0.01 & 0.06 & 101.20 \\
\hline & $132824 a-C X$ & 0.05 & 47.89 & 0.16 & 6.01 & 0.29 & 0.00 & 42.01 & 0.97 & 2.10 & 0.11 & 0.01 & 0.04 & 99.59 \\
\hline & 132824a-Dx & 0.03 & 49.07 & 0.13 & 5.61 & 0.33 & 0.01 & 43.18 & 0.90 & 2.29 & 0.03 & 0.00 & 0.02 & 101.58 \\
\hline & $132824 a-F X$ & 0.02 & 47.31 & 0.13 & 7.48 & 0.32 & 0.00 & 41.62 & 0.90 & 2.25 & 0.05 & 0.01 & 0.03 & 100.07 \\
\hline & $212823 b-A x$ & 0.10 & 48.02 & 0.13 & 4.98 & 0.42 & 0.02 & 42.01 & 1.00 & 2.82 & 0.06 & 0.04 & 0.02 & 99.59 \\
\hline & 212823b-DX & 0.05 & 47.86 & 0.16 & 5.32 & 0.36 & 0.01 & 42.04 & 0.91 & 2.68 & 0.04 & 0.01 & 0.03 & 99.43 \\
\hline & 212823b-DXb & 0.06 & 46.71 & 0.17 & 7.09 & 0.38 & 0.00 & 40.99 & 0.92 & 2.60 & 0.06 & 0.01 & 0.01 & 98.99 \\
\hline & $212823 b-E X$ & 0.08 & 47.42 & 0.19 & 6.12 & 0.39 & 0.00 & 41.62 & 0.90 & 2.72 & 0.05 & 0.02 & 0.00 & 99.50 \\
\hline & 132828-AX & 0.04 & 47.99 & 0.09 & 5.89 & 0.33 & 0.01 & 42.22 & 0.87 & 2.00 & 0.05 & 0.03 & 0.00 & 99.52 \\
\hline & $132828-C X$ & 0.06 & 47.90 & 0.11 & 6.51 & 0.36 & 0.00 & 41.98 & 0.99 & 1.68 & 0.06 & 0.02 & 0.00 & 99.68 \\
\hline & 132828-R4X & 0.07 & 47.93 & 0.13 & 6.57 & 0.38 & 0.02 & 42.14 & 0.83 & 1.92 & 0.05 & 0.00 & 0.05 & 100.05 \\
\hline & 132828-ОTX & 0.08 & 48.86 & 0.08 & 5.48 & 0.27 & 0.01 & 42.90 & 0.90 & 1.80 & 0.05 & 0.00 & 0.08 & 100.43 \\
\hline & $212825-A X$ & 0.09 & 48.84 & 0.16 & 4.69 & 0.04 & 0.00 & 43.15 & 0.62 & 2.57 & 0.05 & 0.02 & 0.01 & 100.23 \\
\hline & 212825-BX & 0.07 & 48.17 & 0.12 & 5.54 & 0.05 & 0.00 & 42.59 & 0.61 & 2.10 & 0.04 & 0.02 & 0.00 & 99.30 \\
\hline & 212825-EX & 0.10 & 48.73 & 0.14 & 5.01 & 0.05 & 0.00 & 43.09 & 0.56 & 2.40 & 0.03 & 0.02 & 0.02 & 100.13 \\
\hline & 212825-FX & 0.06 & 48.52 & 0.12 & 5.33 & 0.06 & 0.00 & 42.88 & 0.66 & 2.04 & 0.04 & 0.01 & 0.00 & 99.73 \\
\hline & 132826-AX & 0.04 & 47.70 & 0.17 & 5.53 & 0.40 & 0.02 & 42.32 & 0.53 & 2.39 & 0.03 & 0.05 & 0.00 & 99.17 \\
\hline & 132826-BX & 0.07 & 48.19 & 0.11 & 5.37 & 0.30 & 0.02 & 42.66 & 0.56 & 2.15 & 0.03 & 0.05 & 0.00 & 99.49 \\
\hline & 132826-DX & 0.02 & 47.23 & 0.13 & 6.77 & 0.34 & 0.00 & 41.82 & 0.62 & 2.04 & 0.03 & 0.01 & 0.00 & 99.01 \\
\hline & 132826-EX & 0.04 & 48.41 & 0.16 & 4.97 & 0.37 & 0.00 & 42.83 & 0.64 & 2.37 & 0.04 & 0.04 & 0.00 & 99.86 \\
\hline & 132826-FX & 0.05 & 47.86 & 0.11 & 5.41 & 0.37 & 0.02 & 42.31 & 0.64 & 2.08 & 0.03 & 0.03 & 0.00 & 98.90 \\
\hline
\end{tabular}


Table 3. 2011 eruptive event oxides EMPA data.

\begin{tabular}{|c|c|c|c|c|c|c|c|c|c|c|c|c|c|c|}
\hline & Sample & $\mathrm{SiO} 2$ & $\mathrm{TiO} 2$ & $\mathrm{Al} 2 \mathrm{O} 3$ & $\mathrm{Fe} 2 \mathrm{O} 3$ & V2O3 & $\mathrm{Cr} 2 \mathrm{O} 3$ & $\mathrm{FeO}$ & $\mathrm{MnO}$ & $\mathrm{MgO}$ & $\mathrm{CaO}$ & $\mathrm{ZnO}$ & $\mathrm{NiO}$ & Total \\
\hline M & DTCCL11-G1 & 0.10 & 17.26 & 1.60 & 33.54 & 0.45 & 0.01 & 45.24 & 0.70 & 1.09 & 0.03 & 0.04 & 0.01 & 100.07 \\
\hline $\begin{array}{l}\mathrm{d} \\
\mathrm{g}\end{array}$ & DTCCL11-EX & 0.13 & 19.59 & 1.60 & 30.32 & 0.38 & 0.00 & 48.15 & 0.50 & 1.20 & 0.02 & 0.03 & 0.02 & 101.93 \\
\hline $\mathrm{n}$ & DTCCL11-R1 & 0.14 & 19.89 & 1.23 & 28.91 & 0.25 & 0.01 & 47.74 & 0.80 & 1.03 & 0.02 & 0.04 & 0.01 & 100.05 \\
\hline $\begin{array}{l}e \\
t\end{array}$ & DTCCL11-R4 & 0.12 & 17.91 & 1.63 & 32.45 & 0.39 & 0.01 & 45.80 & 0.79 & 1.13 & 0.01 & 0.07 & 0.01 & 100.31 \\
\hline $\mathrm{i}$ & PMH11-vs & 0.09 & 17.97 & 1.80 & 32.45 & 0.22 & 0.01 & 45.98 & 0.79 & 1.73 & 0.03 & 0.04 & 0.05 & 101.11 \\
\hline $\begin{array}{l}\mathrm{t} \\
\mathrm{e}\end{array}$ & PMH11-hm & 0.06 & 17.61 & 1.67 & 34.66 & 0.33 & 0.01 & 46.43 & 0.72 & 1.66 & 0.04 & 0.05 & 0.00 & 103.23 \\
\hline $\mathrm{s}$ & PMH11-sg & 0.02 & 18.59 & 1.74 & 33.68 & 0.31 & 0.00 & 48.00 & 0.56 & 1.48 & 0.03 & 0.04 & 0.03 & 104.46 \\
\hline I & DTCCL11-G1 & 0.02 & 48.24 & 0.10 & 5.32 & 0.45 & 0.01 & 42.39 & 0.95 & 1.69 & 0.10 & 0.02 & 0.06 & 99.28 \\
\hline I & DTCCL11-EX & 0.06 & 49.66 & 0.10 & 4.61 & 0.33 & 0.01 & 43.91 & 0.64 & 1.78 & 0.04 & 0.02 & 0.02 & 101.17 \\
\hline $\begin{array}{l}\mathrm{m} \\
\mathrm{e}\end{array}$ & DTCCL11-R1 & 0.04 & 48.44 & 0.09 & 5.72 & 0.27 & 0.00 & 42.46 & 1.04 & 1.58 & 0.04 & 0.01 & 0.05 & 99.69 \\
\hline $\mathrm{n}$ & DTCCL11-R4 & 0.06 & 49.06 & 0.09 & 4.26 & 0.35 & 0.00 & 42.88 & 1.12 & 1.79 & 0.03 & 0.07 & 0.00 & 99.71 \\
\hline $\mathrm{i}$ & PMH11-vs & 0.01 & 49.11 & 0.14 & 3.96 & 0.29 & 0.01 & 43.34 & 0.81 & 2.28 & 0.06 & 0.02 & 0.27 & 100.01 \\
\hline e & PMH11-hm & 0.02 & 48.92 & 0.18 & 4.43 & 0.34 & 0.00 & 43.10 & 0.85 & 2.79 & 0.02 & 0.01 & 0.02 & 100.67 \\
\hline $\mathrm{s}$ & PMH11-sg & 0.02 & 18.61 & 1.73 & 31.20 & 0.31 & 0.00 & 46.92 & 0.57 & 1.48 & 0.03 & 0.04 & 0.03 & 100.90 \\
\hline
\end{tabular}


Table 4. 1921 Plagioclase EMPA data, green phenocrysts, white microliths.

\begin{tabular}{|c|c|c|c|c|c|c|c|c|c|c|c|c|c|}
\hline Sample & $\mathrm{SiO} 2$ & $\mathrm{TiO} 2$ & $\mathrm{Al} 2 \mathrm{O} 3$ & $\mathrm{FeO}$ & $\mathrm{MnO}$ & $\mathrm{MgO}$ & $\mathrm{CaO}$ & $\mathrm{Na} 2 \mathrm{O}$ & $\mathrm{K} 2 \mathrm{O}$ & Total & An & $A b$ & Or \\
\hline 42823a-pl-C1 & 59.16 & 0.09 & 25.85 & 0.51 & 0.02 & 0.06 & 8.17 & 6.69 & 0.37 & 100.92 & 0.39 & 0.58 & 0.02 \\
\hline 42823a-pl-r2 & 59.58 & 0.06 & 25.36 & 0.53 & 0.00 & 0.05 & 8.00 & 7.09 & 0.42 & 101.09 & 0.38 & 0.60 & 0.02 \\
\hline 42823a-pl-r4 & 59.56 & 0.07 & 25.65 & 0.47 & 0.02 & 0.04 & 8.18 & 6.96 & 0.46 & 101.40 & 0.38 & 0.59 & 0.03 \\
\hline 42823a-pl-r5m & 63.72 & 0.13 & 22.92 & 0.87 & 0.00 & 0.04 & 4.89 & 7.69 & 0.91 & 101.17 & 0.25 & 0.70 & 0.05 \\
\hline 42823a-pl-otm & 61.88 & 0.01 & 24.18 & 0.74 & 0.02 & 0.03 & 6.18 & 7.44 & 0.72 & 101.19 & 0.30 & 0.66 & 0.04 \\
\hline 42823a-pl-otm2 & 60.47 & 0.04 & 24.62 & 0.67 & 0.03 & 0.04 & 6.97 & 7.39 & 0.62 & 100.84 & 0.33 & 0.63 & 0.03 \\
\hline $42823 b-p l-r 3$ & 59.77 & 0.07 & 25.24 & 0.47 & 0.00 & 0.03 & 7.68 & 6.89 & 0.42 & 100.56 & 0.37 & 0.61 & 0.02 \\
\hline 42823b-pl-r2 & 59.52 & 0.01 & 25.56 & 0.56 & 0.02 & 0.03 & 8.21 & 6.59 & 0.41 & 100.92 & 0.40 & 0.58 & 0.02 \\
\hline 42823b-pl-r4 & 60.08 & 0.06 & 25.38 & 0.48 & 0.00 & 0.04 & 7.49 & 7.17 & 0.44 & 101.14 & 0.34 & 0.63 & 0.03 \\
\hline $42823 b-p l-r 4 m$ & 58.82 & 0.10 & 25.51 & 0.68 & 0.04 & 0.06 & 8.14 & 6.76 & 0.44 & 100.55 & 0.40 & 0.58 & 0.02 \\
\hline 42823b-pl-r3m & 62.73 & 0.06 & 24.45 & 0.58 & 0.01 & 0.05 & 6.34 & 7.38 & 0.59 & 102.19 & 0.34 & 0.63 & 0.03 \\
\hline $42823 b-p l-r 1 m$ & 60.03 & 0.11 & 24.28 & 0.65 & 0.05 & 0.03 & 6.30 & 7.58 & 0.58 & 99.61 & 0.30 & 0.66 & 0.03 \\
\hline 42825-pl-r5 & 59.61 & 0.08 & 25.56 & 0.42 & 0.04 & 0.03 & 7.96 & 6.81 & 0.38 & 100.88 & 0.38 & 0.59 & 0.02 \\
\hline $42825-p l-r 1$ & 57.25 & 0.13 & 25.81 & 0.61 & 0.00 & 0.04 & 8.78 & 6.70 & 0.39 & 99.71 & 0.41 & 0.57 & 0.02 \\
\hline $42825-p l-r 3 s$ & 58.89 & 0.11 & 25.39 & 0.49 & 0.07 & 0.04 & 7.90 & 6.83 & 0.44 & 100.17 & 0.38 & 0.59 & 0.03 \\
\hline $42825-\mathrm{pl}-\mathrm{r} 3 \mathrm{~m}$ & 62.80 & 0.14 & 23.49 & 0.86 & 0.05 & 0.03 & 6.29 & 6.29 & 0.84 & 100.79 & 0.30 & 0.65 & 0.05 \\
\hline 42825-pl-r1m & 62.40 & 0.16 & 23.35 & 0.84 & 0.01 & 0.04 & 5.82 & 7.34 & 1.00 & 100.95 & 0.29 & 0.65 & 0.06 \\
\hline 42825-pl-r4m & 62.85 & 0.14 & 23.17 & 0.60 & 0.02 & 0.01 & 5.92 & 7.28 & 0.92 & 100.91 & 0.29 & 0.65 & 0.05 \\
\hline 42828-pl-r1 & 59.25 & 0.10 & 25.36 & 0.54 & 0.03 & 0.04 & 8.11 & 6.94 & 0.41 & 100.77 & 0.38 & 0.59 & 0.02 \\
\hline 42828-pl-r2 & 58.68 & 0.08 & 25.60 & 0.56 & 0.04 & 0.04 & 8.08 & 6.48 & 0.41 & 99.98 & 0.40 & 0.58 & 0.02 \\
\hline 42828-pl-r3 & 58.69 & 0.15 & 25.27 & 0.58 & 0.02 & 0.02 & 7.47 & 6.98 & 0.48 & 99.67 & 0.36 & 0.61 & 0.03 \\
\hline 42828-pl-r4 & 59.84 & 0.05 & 25.57 & 0.53 & 0.01 & 0.04 & 7.55 & 6.82 & 0.46 & 100.86 & 0.37 & 0.60 & 0.03 \\
\hline 42828-pl-Dm & 61.90 & 0.06 & 24.09 & 0.50 & 0.05 & 0.02 & 6.11 & 7.51 & 0.81 & 101.03 & 0.30 & 0.66 & 0.05 \\
\hline 42828-pl-r5m & 62.69 & 0.19 & 23.74 & 0.76 & 0.01 & 0.03 & 5.74 & 7.62 & 0.70 & 101.49 & 0.28 & 0.68 & 0.04 \\
\hline 72822-plnw & 57.29 & 0.16 & 26.18 & 0.52 & 0.04 & 0.05 & 8.56 & 6.36 & 0.35 & 99.51 & 0.42 & 0.56 & 0.02 \\
\hline 72822-plot & 58.83 & 0.14 & 26.14 & 0.57 & 0.00 & 0.03 & 8.39 & 6.56 & 0.41 & 101.05 & 0.41 & 0.57 & 0.02 \\
\hline 72822plr1 & 56.82 & 0.06 & 26.04 & 0.50 & 0.00 & 0.06 & 8.41 & 6.66 & 0.38 & 98.92 & 0.40 & 0.58 & 0.02 \\
\hline 72822-plsm & 60.95 & 0.07 & 23.81 & 0.74 & 0.02 & 0.02 & 5.40 & 7.98 & 0.85 & 99.85 & 0.26 & 0.69 & 0.05 \\
\hline 72822-plotm & 60.93 & 0.13 & 24.76 & 0.68 & 0.01 & 0.03 & 6.88 & 7.31 & 0.59 & 101.31 & 0.33 & 0.64 & 0.03 \\
\hline 72822-pIr1m & 59.08 & 0.17 & 24.96 & 0.62 & 0.00 & 0.03 & 7.01 & 7.09 & 0.49 & 99.47 & 0.34 & 0.63 & 0.03 \\
\hline
\end{tabular}


Table 5. 1960 Plagioclase EMPA data, green phenocrysts, white microliths.

\begin{tabular}{|c|c|c|c|c|c|c|c|c|c|c|c|c|c|}
\hline Sample & $\mathrm{Na} 2 \mathrm{O}$ & $\mathrm{TiO} 2$ & $\mathrm{CaO}$ & $\mathrm{MnO}$ & $\mathrm{MgO}$ & $\mathrm{FeO}$ & $\mathrm{K} 2 \mathrm{O}$ & $\mathrm{Al} 2 \mathrm{O} 3$ & $\mathrm{SiO}_{2}$ & Total & An & $A b$ & Or \\
\hline 132824a-pl-A1 & 7.15 & 0.10 & 7.55 & 0.04 & 0.04 & 0.43 & 0.45 & 24.93 & 59.93 & 100.60 & 0.36 & 0.62 & 0.03 \\
\hline 132824a-pl-A2 & 7.12 & 0.06 & 7.38 & 0.00 & 0.01 & 0.52 & 0.47 & 24.69 & 60.12 & 100.36 & 0.35 & 0.62 & 0.03 \\
\hline 132824a-pl-R2 & 7.05 & 0.12 & 6.83 & 0.06 & 0.02 & 0.42 & 0.51 & 24.24 & 60.28 & 99.52 & 0.34 & 0.63 & 0.03 \\
\hline 132824a-pl-C1 & 6.96 & 0.03 & 7.33 & 0.00 & 0.02 & 0.44 & 0.47 & 24.56 & 60.69 & 100.51 & 0.36 & 0.61 & 0.03 \\
\hline 132824a-pl-B1 & 7.92 & 0.06 & 4.38 & 0.01 & 0.02 & 0.45 & 0.96 & 22.31 & 64.88 & 100.99 & 0.22 & 0.72 & 0.06 \\
\hline 132824a-pl-R5 & 7.36 & 0.15 & 6.76 & 0.03 & 0.03 & 0.43 & 0.53 & 24.30 & 60.96 & 100.55 & 0.33 & 0.64 & 0.03 \\
\hline 132824a-pl-ot & 8.49 & 0.05 & 4.40 & 0.05 & 0.02 & 0.53 & 1.00 & 22.04 & 63.97 & 100.55 & 0.21 & 0.73 & 0.06 \\
\hline 132826-pl-r2 & 7.09 & 0.11 & 7.51 & 0.00 & 0.03 & 0.47 & 0.48 & 24.62 & 59.55 & 99.86 & 0.36 & 0.61 & 0.03 \\
\hline 132826-pl-r5 & 7.35 & 0.02 & 7.20 & 0.03 & 0.03 & 0.44 & 0.49 & 24.71 & 60.55 & 100.81 & 0.34 & 0.63 & 0.03 \\
\hline 132826-pl-r8 & 7.31 & 0.10 & 7.08 & 0.06 & 0.03 & 0.46 & 0.51 & 24.17 & 59.70 & 99.42 & 0.34 & 0.63 & 0.03 \\
\hline 132826-pl-r2m & 7.46 & 0.18 & 4.47 & 0.02 & 0.02 & 0.93 & 1.24 & 21.32 & 64.55 & 100.20 & 0.23 & 0.69 & 0.08 \\
\hline 132826-pl-r7m & 8.67 & 0.06 & 3.49 & 0.00 & 0.00 & 0.30 & 1.17 & 22.22 & 65.35 & 101.26 & 0.17 & 0.76 & 0.07 \\
\hline 132826-pl-r8m & 8.07 & 0.15 & 4.55 & 0.04 & 0.02 & 0.80 & 1.09 & 21.85 & 64.14 & 100.71 & 0.22 & 0.71 & 0.06 \\
\hline 132828pl-A1 & 6.86 & 0.14 & 7.89 & 0.02 & 0.02 & 0.47 & 0.42 & 25.21 & 59.21 & 100.26 & 0.38 & 0.60 & 0.02 \\
\hline $132828 p l-r 1$ & 6.92 & 0.05 & 7.38 & 0.01 & 0.02 & 0.53 & 0.44 & 24.98 & 60.58 & 100.90 & 0.36 & 0.61 & 0.03 \\
\hline 132828pl-g1 & 7.04 & 0.01 & 7.53 & 0.04 & 0.03 & 0.51 & 0.45 & 24.38 & 60.25 & 100.23 & 0.36 & 0.61 & 0.03 \\
\hline 132828pl-R2b & 7.26 & 0.04 & 7.56 & 0.06 & 0.04 & 0.53 & 0.43 & 24.68 & 59.97 & 100.56 & 0.36 & 0.62 & 0.02 \\
\hline 132828pl-E1 & 7.39 & 0.12 & 7.29 & 0.00 & 0.02 & 0.46 & 0.53 & 24.66 & 61.02 & 101.48 & 0.34 & 0.63 & 0.03 \\
\hline 132828pl-R5 & 7.15 & 0.05 & 7.05 & 0.05 & 0.02 & 0.46 & 0.52 & 24.91 & 60.85 & 101.06 & 0.33 & 0.64 & 0.03 \\
\hline $132828 \mathrm{pl}-\mathrm{Ot}$ & 7.11 & 0.02 & 5.81 & 0.02 & 0.03 & 0.46 & 0.70 & 23.44 & 63.14 & 100.73 & 0.29 & 0.67 & 0.04 \\
\hline 212823b-pl-r2 & 7.20 & 0.04 & 7.21 & 0.03 & 0.01 & 0.40 & 0.48 & 24.77 & 59.98 & 100.12 & 0.35 & 0.63 & 0.03 \\
\hline 212823b-pl-C1 & 7.03 & 0.05 & 7.21 & 0.05 & 0.03 & 0.49 & 0.46 & 24.46 & 60.38 & 100.15 & 0.35 & 0.62 & 0.03 \\
\hline 212823b-pl-C1cl & 6.67 & 0.13 & 7.32 & 0.05 & 0.04 & 0.51 & 0.47 & 24.69 & 58.64 & 98.53 & 0.37 & 0.60 & 0.03 \\
\hline 212823b-pl-C1b & 6.88 & 0.07 & 7.50 & 0.02 & 0.04 & 0.45 & 0.42 & 24.51 & 59.91 & 99.80 & 0.37 & 0.61 & 0.02 \\
\hline 212823b-pl-C1m & 7.57 & 0.11 & 5.77 & 0.03 & 0.02 & 0.50 & 0.61 & 23.99 & 63.72 & 102.31 & 0.29 & 0.68 & 0.04 \\
\hline 212823b-pl-Cm & 5.86 & 0.29 & 3.99 & 0.10 & 0.13 & 1.71 & 1.43 & 19.98 & 65.88 & 99.37 & 0.26 & 0.70 & 0.04 \\
\hline 212823b-pl-Cm2 & 7.07 & 0.17 & 6.66 & 0.03 & 0.03 & 0.58 & 0.50 & 24.34 & 59.13 & 98.50 & 0.33 & 0.64 & 0.03 \\
\hline 212825-pl-c1 & 6.99 & 0.02 & 7.83 & 0.02 & 0.03 & 0.50 & 0.40 & 25.09 & 59.52 & 100.40 & 0.36 & 0.61 & 0.03 \\
\hline 212825-pl-r1 & 7.11 & 0.08 & 7.36 & 0.03 & 0.02 & 0.43 & 0.49 & 24.46 & 59.95 & 99.93 & 0.34 & 0.63 & 0.03 \\
\hline 212825-pl-r3 & 7.18 & 0.08 & 7.20 & 0.03 & 0.03 & 0.55 & 0.45 & 24.26 & 59.52 & 99.30 & 0.34 & 0.63 & 0.03 \\
\hline 212825-pl-cm & 7.93 & 0.15 & 5.83 & 0.04 & 0.03 & 0.64 & 0.71 & 23.39 & 62.47 & 101.19 & 0.23 & 0.69 & 0.08 \\
\hline 212825-pl-r2m & 7.83 & 0.18 & 4.51 & 0.03 & 0.06 & 0.99 & 1.30 & 21.30 & 65.20 & 101.39 & 0.17 & 0.76 & 0.07 \\
\hline 212825-pl-r3m & 7.64 & 0.15 & 5.83 & 0.03 & 0.02 & 0.62 & 0.70 & 23.04 & 62.14 & 100.16 & 0.22 & 0.71 & 0.06 \\
\hline
\end{tabular}


Table 6. 2011 Plagioclase EMPA data, green phenocrysts, white microliths.

\begin{tabular}{|c|c|c|c|c|c|c|c|c|c|c|c|c|c|}
\hline Samples & $\mathrm{SiO} 2$ & TiO2 & Al2O3 & $\mathrm{FeO}$ & $\mathrm{MnO}$ & $\mathrm{MgO}$ & $\mathrm{CaO}$ & $\mathrm{Na} 2 \mathrm{O}$ & K2O & Total & An & $A b$ & Or \\
\hline dtccl11-pl-r5 & 59.32 & 0.01 & 24.95 & 0.44 & 0.00 & 0.01 & 7.45 & 7.35 & 0.50 & 100.04 & 0.35 & 0.52 & 0.04 \\
\hline dtccl11-pl-r2 & 59.67 & 0.00 & 24.90 & 0.45 & 0.06 & 0.02 & 7.19 & 6.82 & 0.53 & 99.60 & 0.36 & 0.61 & 0.05 \\
\hline dtccl11-pl-r2b & 59.14 & 0.10 & 25.40 & 0.56 & 0.02 & 0.04 & 7.38 & 6.93 & 0.61 & 100.13 & 0.36 & 0.61 & 0.03 \\
\hline dtccl11-pl-r3m & 61.26 & 0.09 & 24.36 & 0.65 & 0.09 & 0.01 & 6.08 & 7.42 & 0.79 & 100.66 & 0.30 & 0.66 & 0.03 \\
\hline dtccl11-pl-r1m & 64.05 & 0.05 & 22.69 & 0.53 & 0.00 & 0.03 & 4.66 & 7.44 & 1.12 & 100.57 & 0.23 & 0.70 & 0.07 \\
\hline dtccl11-pl-bm & 63.29 & 0.15 & 23.02 & 0.50 & 0.05 & 0.01 & 4.92 & 8.25 & 1.06 & 101.21 & 0.23 & 0.71 & 0.04 \\
\hline pmhvs11-pl1 & 5.89 & 0.60 & 7.99 & 0.02 & 0.34 & 2.20 & 0.63 & 24.02 & 57.46 & 98.82 & 0.23 & 0.70 & 0.07 \\
\hline pmh11-pl & 6.82 & 0.08 & 7.48 & 0.02 & 0.02 & 0.46 & 0.40 & 25.18 & 58.36 & 98.80 & 0.36 & 0.61 & 0.03 \\
\hline pmh11-pl1 & 6.94 & 0.10 & 7.43 & 0.00 & 0.03 & 0.38 & 0.38 & 24.90 & 59.11 & 99.24 & 0.36 & 0.61 & 0.04 \\
\hline pmh11-pl2 & 7.08 & 0.11 & 7.15 & 0.01 & 0.03 & 0.41 & 0.43 & 24.99 & 59.71 & 99.89 & 0.30 & 0.66 & 0.05 \\
\hline pmvs11-pl1 & 6.88 & 0.07 & 7.41 & 0.01 & 0.03 & 0.38 & 0.39 & 25.20 & 58.23 & 98.57 & 0.23 & 0.71 & 0.06 \\
\hline
\end{tabular}


Table 7. 1921 eruptive event pyroxene EMPA data, white Opx, green Cpx.

\begin{tabular}{|c|c|c|c|c|c|c|c|c|c|c|c|c|c|c|}
\hline Sample & $\mathrm{Na} 2 \mathrm{O}$ & $\mathrm{TiO} 2$ & $\mathrm{SiO} 2$ & $\mathrm{MnO}$ & $\mathrm{MgO}$ & V2O3 & $\mathrm{CaO}$ & $\mathrm{Cr} 2 \mathrm{O} 3$ & Al2O3 & $\mathrm{FeO}$ & Total & Wo & En & $\mathrm{Fa}$ \\
\hline 42823A-PX-R3OT & 0.05 & 0.31 & 49.40 & 0.62 & 23.19 & 0.00 & 1.76 & 0.00 & 0.62 & 24.04 & 100.00 & 0.03 & 0.61 & 0.36 \\
\hline 42823A-PX-R4 & 0.05 & 0.26 & 48.85 & 0.57 & 22.38 & 0.01 & 1.75 & 0.01 & 0.51 & 25.61 & 100.00 & 0.03 & 0.59 & 0.38 \\
\hline 42823A-PX-R5 & 0.09 & 0.29 & 48.97 & 0.51 & 22.37 & 0.04 & 1.80 & 0.02 & 0.56 & 25.35 & 100.00 & 0.03 & 0.59 & 0.38 \\
\hline 42823A-PX-R3 & 0.33 & 0.49 & 48.07 & 0.45 & 15.49 & 0.03 & 20.05 & 0.01 & 1.11 & 13.98 & 100.00 & 0.38 & 0.41 & 0.21 \\
\hline 42823A-PX-OT & 0.29 & 0.49 & 49.15 & 0.38 & 15.21 & 0.02 & 19.36 & 0.00 & 1.13 & 13.96 & 100.00 & 0.38 & 0.41 & 0.21 \\
\hline 42823A-PX-A & 0.33 & 0.53 & 48.75 & 0.29 & 15.60 & 0.08 & 19.28 & 0.02 & 1.20 & 13.93 & 100.00 & 0.37 & 0.42 & 0.21 \\
\hline 42823b-PX-R2 & 0.06 & 0.27 & 48.52 & 0.69 & 21.45 & 0.01 & 1.82 & 0.01 & 0.46 & 26.72 & 100.00 & 0.03 & 0.57 & 0.40 \\
\hline 42823b-PX-R5ot & 0.05 & 0.27 & 49.90 & 0.75 & 22.21 & 0.04 & 1.82 & 0.00 & 0.53 & 24.41 & 100.00 & 0.04 & 0.60 & 0.37 \\
\hline 42823b-PX-G & 0.07 & 0.45 & 48.77 & 0.65 & 22.53 & 0.02 & 2.01 & 0.01 & 0.86 & 24.63 & 100.00 & 0.04 & 0.60 & 0.37 \\
\hline 42823b-PX-A & 0.29 & 0.37 & 49.43 & 0.47 & 15.29 & 0.03 & 19.40 & 0.01 & 0.99 & 13.72 & 100.00 & 0.38 & 0.41 & 0.21 \\
\hline 42823b-PX-R1 & 0.32 & 0.44 & 49.13 & 0.42 & 15.05 & 0.03 & 19.54 & 0.01 & 1.01 & 14.06 & 100.00 & 0.38 & 0.41 & 0.21 \\
\hline 42823b-PX-R4 & 0.32 & 0.51 & 48.09 & 0.45 & 16.06 & 0.01 & 19.19 & 0.00 & 1.22 & 14.16 & 100.00 & 0.36 & 0.42 & 0.21 \\
\hline 42825-PX-R5 & 0.06 & 0.35 & 49.02 & 0.67 & 22.61 & 0.04 & 1.94 & 0.00 & 0.68 & 24.63 & 100.00 & 0.04 & 0.60 & 0.37 \\
\hline 42825-PX-G & 0.04 & 0.25 & 49.50 & 0.70 & 22.38 & 0.09 & 1.89 & 0.00 & 0.59 & 24.55 & 100.00 & 0.04 & 0.60 & 0.37 \\
\hline 42825-PX-F & 0.04 & 0.26 & 49.08 & 0.63 & 23.00 & 0.04 & 1.79 & 0.00 & 0.52 & 24.64 & 100.00 & 0.03 & 0.60 & 0.36 \\
\hline 42825-PX-R4 & 0.34 & 0.47 & 48.69 & 0.42 & 15.86 & 0.05 & 19.53 & 0.01 & 1.12 & 13.52 & 100.00 & 0.37 & 0.42 & 0.20 \\
\hline 42825-PX-R3 & 0.33 & 0.32 & 48.77 & 0.46 & 14.67 & 0.04 & 19.45 & 0.02 & 0.96 & 15.00 & 100.00 & 0.38 & 0.40 & 0.23 \\
\hline 42825-PX-R2 & 0.29 & 0.34 & 48.81 & 0.41 & 15.61 & 0.08 & 19.47 & 0.00 & 1.05 & 13.94 & 100.00 & 0.37 & 0.42 & 0.21 \\
\hline 42828-PX-R2 & 0.03 & 0.27 & 49.21 & 0.57 & 21.76 & 0.02 & 1.81 & 0.00 & 0.49 & 25.83 & 100.00 & 0.03 & 0.58 & 0.39 \\
\hline 42828-PX-R2B & 0.07 & 0.25 & 48.73 & 0.60 & 22.26 & 0.01 & 1.86 & 0.02 & 0.51 & 25.69 & 100.00 & 0.04 & 0.59 & 0.38 \\
\hline 42828-PX-R3 & 0.07 & 0.23 & 49.08 & 0.70 & 21.51 & 0.02 & 1.79 & 0.01 & 0.48 & 26.12 & 100.00 & 0.03 & 0.57 & 0.39 \\
\hline 42828-PX-C & 0.31 & 0.54 & 48.49 & 0.38 & 15.49 & 0.04 & 19.66 & 0.02 & 1.05 & 14.02 & 100.00 & 0.38 & 0.41 & 0.21 \\
\hline 42828-PX-A & 0.30 & 0.53 & 48.24 & 0.38 & 15.58 & 0.06 & 19.79 & 0.03 & 1.02 & 14.07 & 100.00 & 0.38 & 0.41 & 0.21 \\
\hline 42828-PX-COT & 0.30 & 0.35 & 48.81 & 0.37 & 15.33 & 0.09 & 19.51 & 0.01 & 1.03 & 14.21 & 100.00 & 0.38 & 0.41 & 0.21 \\
\hline
\end{tabular}


Table 8. 1960 eruptive event pyroxene EMPA data, white Opx, green Cpx.

\begin{tabular}{|c|c|c|c|c|c|c|c|c|c|c|c|c|c|c|}
\hline Sample & $\mathrm{Na} 2 \mathrm{O}$ & $\mathrm{TiO} 2$ & $\mathrm{SiO} 2$ & $\mathrm{MnO}$ & $\mathrm{MgO}$ & V2O3 & $\mathrm{CaO}$ & $\mathrm{Cr} 2 \mathrm{O} 3$ & $\mathrm{Al} 2 \mathrm{O} 3$ & $\mathrm{FeO}$ & Total & Wo & En & $\mathrm{Fa}$ \\
\hline 132824a-PX-R2 & 0.09 & 0.31 & 49.50 & 0.73 & 20.60 & 0.01 & 1.83 & 0.00 & 0.55 & 26.39 & 100.00 & 0.04 & 0.56 & 0.40 \\
\hline 132824a-PX-R4 & 0.04 & 0.21 & 48.49 & 0.86 & 19.99 & 0.01 & 1.71 & 0.01 & 0.49 & 28.19 & 100.00 & 0.03 & 0.54 & 0.43 \\
\hline 132824a-PX-R4OT & 0.03 & 0.37 & 48.80 & 0.85 & 20.66 & 0.00 & 1.81 & 0.00 & 0.53 & 26.96 & 100.00 & 0.04 & 0.56 & 0.41 \\
\hline 132824a-PX-R3 & 0.28 & 0.34 & 49.28 & 0.51 & 13.36 & 0.00 & 19.34 & 0.00 & 0.82 & 16.08 & 100.00 & 0.38 & 0.37 & 0.25 \\
\hline 132824a-PX-R2OT & 0.33 & 0.34 & 49.29 & 0.45 & 14.17 & 0.02 & 19.28 & 0.02 & 0.95 & 15.14 & 100.00 & 0.38 & 0.39 & 0.23 \\
\hline 132824a-PX-R1 & 0.32 & 0.40 & 49.35 & 0.51 & 14.23 & 0.02 & 19.29 & 0.00 & 1.02 & 14.86 & 100.00 & 0.38 & 0.39 & 0.23 \\
\hline 132826f-px1 & 0.05 & 0.34 & 51.10 & 0.83 & 19.27 & 0.02 & 1.84 & 0.02 & 0.55 & 25.99 & 100.00 & 0.04 & 0.55 & 0.41 \\
\hline 132826r3-px1 & 0.06 & 0.23 & 51.19 & 0.84 & 18.46 & 0.03 & 1.72 & 0.00 & 0.41 & 27.08 & 100.00 & 0.04 & 0.53 & 0.44 \\
\hline 132826r4-px1 & 0.07 & 0.31 & 50.77 & 0.89 & 18.60 & 0.04 & 1.80 & 0.00 & 0.47 & 27.06 & 100.00 & 0.04 & 0.53 & 0.43 \\
\hline 132826b-px1 & 0.27 & 0.51 & 50.60 & 0.53 & 13.50 & 0.05 & 18.67 & 0.01 & 1.17 & 14.69 & 100.00 & 0.38 & 0.38 & 0.23 \\
\hline 132826r1-px1 & 0.27 & 0.44 & 50.71 & 0.46 & 13.75 & 0.04 & 19.42 & 0.00 & 0.95 & 13.94 & 100.00 & 0.39 & 0.39 & 0.22 \\
\hline 132826r5-px1 & 0.28 & 0.52 & 50.76 & 0.51 & 13.28 & 0.05 & 19.21 & 0.02 & 0.79 & 14.58 & 100.00 & 0.39 & 0.38 & 0.23 \\
\hline 132828-PX-H & 0.07 & 0.28 & 48.49 & 0.90 & 21.12 & 0.02 & 1.72 & 0.01 & 0.51 & 26.89 & 100.00 & 0.03 & 0.56 & 0.40 \\
\hline 132828-PX-R2 & 0.06 & 0.24 & 48.81 & 0.78 & 21.09 & 0.02 & 1.69 & 0.00 & 0.49 & 26.83 & 100.00 & 0.03 & 0.56 & 0.40 \\
\hline 132828-PX-R3 & 0.05 & 0.31 & 48.55 & 0.83 & 19.71 & 0.07 & 1.88 & 0.01 & 0.47 & 28.12 & 100.00 & 0.04 & 0.53 & 0.43 \\
\hline 132828-PX-HOT & 0.07 & 0.36 & 48.03 & 0.93 & 20.48 & 0.04 & 1.86 & 0.00 & 0.65 & 27.56 & 100.00 & 0.04 & 0.55 & 0.41 \\
\hline 132828-PX-D & 0.29 & 0.37 & 49.53 & 0.43 & 14.63 & 0.05 & 19.36 & 0.00 & 0.94 & 14.41 & 100.00 & 0.38 & 0.40 & 0.22 \\
\hline 132828-PX-GOT & 0.34 & 0.42 & 49.89 & 0.52 & 14.03 & 0.02 & 19.01 & 0.00 & 0.83 & 14.95 & 100.00 & 0.38 & 0.39 & 0.23 \\
\hline 212823B-PX-R1 & 0.03 & 0.28 & 48.75 & 1.02 & 20.46 & 0.03 & 1.67 & 0.00 & 0.44 & 27.32 & 100.00 & 0.03 & 0.55 & 0.41 \\
\hline 212823B-PX-A & 0.03 & 0.28 & 48.79 & 0.80 & 21.57 & 0.04 & 1.73 & 0.01 & 0.41 & 26.33 & 100.00 & 0.03 & 0.57 & 0.39 \\
\hline 212823B-PX-F & 0.07 & 0.34 & 48.67 & 0.84 & 20.93 & 0.05 & 1.75 & 0.03 & 0.45 & 26.88 & 100.00 & 0.03 & 0.56 & 0.40 \\
\hline 212823B-PX-R3 & 0.28 & 0.41 & 48.58 & 0.62 & 14.11 & 0.00 & 19.30 & 0.01 & 0.89 & 15.79 & 100.00 & 0.38 & 0.38 & 0.24 \\
\hline 212823B-PX-R3B & 0.39 & 0.66 & 48.22 & 0.54 & 15.14 & 0.00 & 19.23 & 0.00 & 1.45 & 14.36 & 100.00 & 0.37 & 0.41 & 0.22 \\
\hline 212823B-PX-R4OT & 0.32 & 0.36 & 48.97 & 0.53 & 14.38 & 0.01 & 19.77 & 0.01 & 1.05 & 14.61 & 100.00 & 0.39 & 0.39 & 0.22 \\
\hline $212825 c-p \times 1$ & 0.26 & 0.38 & 50.72 & 0.55 & 13.96 & 0.02 & 18.92 & 0.04 & 0.88 & 14.27 & 100.00 & 0.38 & 0.39 & 0.23 \\
\hline 212825r1-px1 & 0.27 & 0.42 & 50.57 & 0.58 & 13.47 & 0.03 & 18.49 & 0.02 & 0.89 & 15.26 & 100.00 & 0.38 & 0.38 & 0.24 \\
\hline 212825r2-px1 & 0.25 & 0.36 & 50.87 & 0.52 & 13.79 & 0.05 & 18.87 & 0.01 & 0.95 & 14.33 & 100.00 & 0.38 & 0.39 & 0.23 \\
\hline
\end{tabular}


Table 9. 2011 eruptive event pyroxene EMPA data, white Opx, green Cpx, blue Castro et al., 2013 da

\begin{tabular}{|c|c|c|c|c|c|c|c|c|c|c|c|c|c|c|}
\hline Sample & $\mathrm{Na} 2 \mathrm{O}$ & TiO2 & $\mathrm{SiO2}$ & $\mathrm{MnO}$ & $\mathrm{MgO}$ & V2O3 & $\mathrm{CaO}$ & $\mathrm{Cr} 2 \mathrm{O3}$ & Al203 & $\mathrm{FeO}$ & Total & Wo & En & $\mathrm{Fa}$ \\
\hline DTCCL11-PX-F2 & 0.05 & 0.27 & 52.88 & 0.80 & 21.00 & 0.03 & 1.70 & 0.02 & 0.60 & 22.65 & 100.00 & 0.03 & 0.60 & 0.36 \\
\hline DTCCL11-PX-R3 & 0.02 & 0.16 & 53.52 & 0.79 & 20.37 & 0.04 & 1.76 & 0.02 & 0.43 & 22.90 & 100.00 & 0.04 & 0.59 & 0.37 \\
\hline DTCCL11-PX-R6 & 0.06 & 0.20 & 53.25 & 0.84 & 19.29 & 0.08 & 1.76 & 0.03 & 0.48 & 24.02 & 100.00 & 0.04 & 0.57 & 0.40 \\
\hline DTCCL11-PX-C1 & 0.05 & 0.15 & 51.02 & 0.79 & 19.27 & 0.03 & 1.43 & 0.00 & 0.44 & 26.82 & 100.00 & 0.03 & 0.55 & 0.43 \\
\hline DTCCL11-PX-F & 0.32 & 0.33 & 53.27 & 0.44 & 14.36 & 0.04 & 15.79 & 0.02 & 1.05 & 14.39 & 100.00 & 0.34 & 0.43 & 0.24 \\
\hline DTCCL11-PX-A & 0.33 & 0.33 & 53.40 & 0.50 & 13.83 & 0.02 & 15.39 & 0.00 & 1.00 & 15.20 & 100.00 & 0.33 & 0.41 & 0.26 \\
\hline PlavaB_px_1_1 $(n=1)$ & 0.23 & 0.93 & 46.99 & 1.70 & 11.40 & 0.00 & 3.36 & 0.04 & 0.93 & 32.20 & 98.01 & 0.07 & 0.35 & 0.58 \\
\hline PlavaB_px_3_2 $(n=1)$ & 0.18 & 0.35 & 50.72 & 1.62 & 12.03 & 0.00 & 4.50 & 0.01 & 1.23 & 28.67 & 99.53 & 0.10 & 0.37 & 0.53 \\
\hline PlavaB_px_4_1 $(n=1)$ & 0.12 & 0.30 & 49.45 & 1.50 & 13.42 & 0.00 & 3.90 & 0.03 & 0.53 & 28.93 & 98.20 & 0.08 & 0.40 & 0.51 \\
\hline PlavaB_px_5_1 $(n=1)$ & 0.22 & 0.61 & 48.90 & 1.52 & 12.07 & 0.00 & 5.28 & 0.03 & 1.22 & 28.11 & 98.11 & 0.12 & 0.37 & 0.51 \\
\hline A-gr4 $(n=4)$ & 0.32 & 0.43 & 51.38 & 0.75 & 13.02 & 0.00 & 18.43 & 0.02 & 1.28 & 14.48 & 100.11 & 0.40 & 0.39 & 0.21 \\
\hline A-gr7b (n=3) & 0.33 & 0.40 & 52.03 & 0.82 & 12.98 & 0.00 & 18.26 & 0.00 & 0.86 & 14.99 & 100.67 & 0.39 & 0.38 & 0.23 \\
\hline A-gr9 $(n=9)$ & 0.30 & 0.39 & 51.92 & 0.73 & 13.39 & 0.00 & 18.50 & 0.02 & 0.98 & 13.96 & 100.20 & 0.39 & 0.40 & 0.21 \\
\hline A-gr19 $(n=3)$ & 0.32 & 0.40 & 51.70 & 0.74 & 13.33 & 0.00 & 18.10 & 0.02 & 1.06 & 14.17 & 99.85 & 0.39 & 0.40 & 0.22 \\
\hline A-gr6 $(n=5)$ & 0.04 & 0.30 & 51.90 & 1.27 & 18.36 & 0.00 & 1.96 & 0.04 & 0.53 & 27.06 & 101.45 & 0.04 & 0.54 & 0.42 \\
\hline A-gr7c $(n=2)$ & 0.03 & 0.25 & 52.17 & 1.20 & 18.70 & 0.00 & 1.70 & 0.01 & 0.44 & 27.17 & 101.70 & 0.04 & 0.54 & 0.42 \\
\hline A-gr20 $(n=4)$ & 0.05 & 0.26 & 52.07 & 1.21 & 19.29 & 0.00 & 1.73 & 0.01 & 0.45 & 26.61 & 101.66 & 0.04 & 0.56 & 0.40 \\
\hline A-gr22 (n=5) & 0.04 & 0.26 & 52.06 & 1.28 & 18.58 & 0.00 & 1.73 & 0.02 & 0.47 & 27.41 & 101.86 & 0.04 & 0.54 & 0.42 \\
\hline
\end{tabular}


Table 10. EPMA standard test for oxides and plagioclase.

\begin{tabular}{|c|c|c|c|c|c|c|c|c|c|c|c|c|}
\hline & \multicolumn{12}{|c|}{ Oxide Standard Test } \\
\hline Elements & $\mathrm{SiO} 2$ & TiO2 & V203 & NiO & Al203 & Cr2O3 & $\mathrm{MnO}$ & ZnO & $\mathrm{MgO}$ & $\mathrm{FeO}$ & $\mathrm{CaO}$ & \multirow{2}{*}{ Total } \\
\hline std name & Augite-EMS1 & Sawyerll-EMS1 & V205-EMS1 & Olivine & Augite-EMS1 & Chromite & Sawyerll-EMS1 & Rhodonite2 & Enstatite & Sawyerll-EMS1 & Augite-EMS1 & \\
\hline Average & 0.102 & 50.307 & 0.413 & 0.010 & 0.010 & 0.101 & 1.523 & 0.020 & 0.262 & 47.451 & 0.005 & 100.203 \\
\hline Std & 0.033 & 0.272 & 0.034 & 0.007 & 0.007 & 0.023 & 0.057 & 0.014 & 0.012 & 0.159 & 0.004 & \\
\hline
\end{tabular}

\begin{tabular}{|c|c|c|c|c|c|c|c|c|c|c|}
\hline & \multicolumn{10}{|c|}{ Plageoclase Standard Test } \\
\hline Elements & $\mathrm{Na} 2 \mathrm{O}$ & TiO2 & $\mathrm{CaO}$ & $\mathrm{MnO}$ & $\mathrm{MgO}$ & $\mathrm{FeO}$ & 120 & Al203 & SiO2 & \multirow{2}{*}{ Total } \\
\hline std name & Albite2 & PyropeGarnet & Plag-AN65 & PyropeGarnet & Kaersutite2 & Kaersutite2 & Kaersutite2 & Plag-AN65 & Albite2 & \\
\hline Average & 4.396 & 0.082 & 11.880 & 0.000 & 0.078 & 0.436 & 0.407 & 28.325 & 53.250 & 98.851 \\
\hline Std & 0.039 & 0.094 & 0.123 & 0.000 & 0.016 & 0.013 & 0.011 & 0.275 & 0.340 & \\
\hline
\end{tabular}


Table 11. Ghiorso and Evans (2008) Thermometry and Oxygen fugacity for 1921 eruptive event

\begin{tabular}{|c|c|c|c|c|c|c|c|}
\hline Sample & Oxide pair & Temperature & Ox fug & Average temp & standard dev & Average Ox Fug & standard dev \\
\hline \multirow{3}{*}{42825} & $r 1 \times 1 / r 1 \times 2$ & 972 & -0.15 & \multirow{3}{*}{973.33} & \multirow{3}{*}{19.04} & \multirow{3}{*}{-0.15} & \multirow{3}{*}{0.12} \\
\hline & r3ox1/r3ox2 & 993 & -0.03 & & & & \\
\hline & $r 3 \times 1 / r 3 \times 2$ & 955 & -0.26 & & & & \\
\hline \multirow{3}{*}{72822} & br1m/br1 & 949 & -0.13 & \multirow{3}{*}{953.33} & \multirow{3}{*}{13.05} & \multirow{3}{*}{-0.14} & \multirow{3}{*}{0.08} \\
\hline & $\mathrm{r} 2 \mathrm{~m} / \mathrm{r} 2$ & 943 & -0.23 & & & & \\
\hline & $\mathrm{r} 1 \mathrm{~m} / \mathrm{r} 1$ & 968 & -0.07 & & & & \\
\hline \multirow{3}{*}{$42823 a$} & $\operatorname{cox} 2 / \operatorname{cox} 1$ & 895 & -0.49 & \multirow{3}{*}{920.33} & \multirow{3}{*}{22.74} & \multirow{3}{*}{-0.40} & \multirow{3}{*}{0.08} \\
\hline & MOTX1/МOTX2 & 927 & -0.39 & & & & \\
\hline & RCLX1/RCLX2 & 939 & -0.33 & & & & \\
\hline \multirow{4}{*}{$42823 b$} & $\mathrm{CX} 1 / \mathrm{Cx} 2$ & 959 & -0.23 & \multirow{4}{*}{951.50} & \multirow{4}{*}{16.05} & \multirow{4}{*}{-0.16} & \multirow{4}{*}{0.09} \\
\hline & EX1/EX2 & 932 & -0.24 & & & & \\
\hline & GX2/GX1 & 969 & -0.06 & & & & \\
\hline & BX3/B2 & 946 & -0.12 & & & & \\
\hline \multirow{5}{*}{42828} & AX4/AX3 & 959 & -0.27 & \multirow{4}{*}{952.50} & \multirow{4}{*}{14.55} & \multirow{4}{*}{-0.26} & \multirow{4}{*}{0.05} \\
\hline & EX2/EX1 & 963 & -0.24 & & & & \\
\hline & ОТХ1/OTX2 & 957 & -0.33 & & & & \\
\hline & OTS1/OTS2 & 931 & -0.2 & & & & \\
\hline & & \multicolumn{2}{|c|}{ Total Average } & 950.20 & 17.09 & -0.22 & 0.08 \\
\hline
\end{tabular}




\begin{tabular}{|c|c|c|c|c|c|c|c|}
\hline Sample & Oxide pair & Temperature & Oxfug & Average temp & standard dev & Average Ox Fug & standard dev \\
\hline \multirow{3}{*}{42825} & r1x1/r1x2 & 972 & -0.15 & \multirow{3}{*}{973.33} & \multirow{3}{*}{19.04} & \multirow{3}{*}{-0.15} & \multirow{3}{*}{0.12} \\
\hline & r3ox1/r3ox2 & 993 & -0.03 & & & & \\
\hline & $r 3 \times 1 / r 3 \times 2$ & 955 & -0.26 & & & & \\
\hline \multirow{3}{*}{72822} & br1m/br1 & 949 & -0.13 & \multirow{3}{*}{953.33} & \multirow{3}{*}{13.05} & \multirow{3}{*}{-0.14} & \multirow{3}{*}{0.08} \\
\hline & $\mathrm{r} 2 \mathrm{~m} / \mathrm{r} 2$ & 943 & -0.23 & & & & \\
\hline & $\mathrm{r} 1 \mathrm{~m} / \mathrm{r} 1$ & 968 & -0.07 & & & & \\
\hline \multirow{3}{*}{$42823 a$} & $\operatorname{cox} 2 / \operatorname{cox} 1$ & 895 & -0.49 & \multirow{3}{*}{920.33} & \multirow{3}{*}{22.74} & \multirow{3}{*}{-0.40} & \multirow{3}{*}{0.08} \\
\hline & МОТХ1/МОТХ2 & 927 & -0.39 & & & & \\
\hline & RCLX1/RCLX2 & 939 & -0.33 & & & & \\
\hline \multirow{4}{*}{$42823 b$} & $\mathrm{CX} 1 / \mathrm{C} \times 2$ & 959 & -0.23 & \multirow{4}{*}{951.50} & \multirow{4}{*}{16.05} & \multirow{4}{*}{-0.16} & \multirow{4}{*}{0.09} \\
\hline & EX1/EX2 & 932 & -0.24 & & & & \\
\hline & GX2/GX1 & 969 & -0.06 & & & & \\
\hline & BX3/B2 & 946 & -0.12 & & & & \\
\hline \multirow{5}{*}{42828} & $A X 4 / A X 3$ & 959 & -0.27 & \multirow{4}{*}{952.50} & \multirow{4}{*}{14.55} & \multirow{4}{*}{-0.26} & \multirow{4}{*}{0.05} \\
\hline & EX2/EX1 & 963 & -0.24 & & & & \\
\hline & ОTХ1/OTX2 & 957 & -0.33 & & & & \\
\hline & OTS1/OTS2 & 931 & -0.2 & & & & \\
\hline & & \multicolumn{2}{|c|}{ Total Average } & 950.20 & 17.09 & -0.22 & 0.08 \\
\hline
\end{tabular}

Table 12. Ghiorso and Evans (2008) Thermometry and Oxygen fugacity for 1960 eruptive event 


\begin{tabular}{|c|c|c|c|c|c|c|c|}
\hline Sample & Oxide pair & Temperature & Ox fug & Average temp & standard dev & Average Ox Fug & standard dev \\
\hline \multirow{4}{*}{$132824 a$} & $a \times 2 / a \times 1$ & 918 & -0.5 & \multirow{4}{*}{926.75} & \multirow{4}{*}{14.45} & \multirow{4}{*}{-0.47} & \multirow{4}{*}{0.03} \\
\hline & $c \times 1 / c \times 2$ & 938 & -0.44 & & & & \\
\hline & $d \times 1 / d \times 2$ & 940 & -0.49 & & & & \\
\hline & $\mathrm{Fx} 2 / \mathrm{f} \times 1$ & 970 & -0.19 & & & & \\
\hline \multirow{3}{*}{$212823 b$} & $d \times 2 / d \times 1$ & 936 & -0.35 & \multirow{3}{*}{963.25} & \multirow{3}{*}{22.87} & \multirow{3}{*}{-0.22} & \multirow{3}{*}{0.1} \\
\hline & $d \times 3 / d \times 4$ & 979 & -0.14 & & & & \\
\hline & ex1/ex2 & 953 & -0.26 & & & & \\
\hline \multirow{4}{*}{132828} & $a \times 2 / a \times 1$ & 934 & -0.52 & \multirow{4}{*}{932.75} & \multirow{4}{*}{14.31} & \multirow{4}{*}{-0.53} & \multirow{4}{*}{0.1} \\
\hline & $\mathrm{c} \times 2 / \mathrm{c} \times 1$ & 932 & -0.5 & & & & \\
\hline & $r 4 \times 2 / r 4 \times 1$ & 950 & -0.43 & & & & \\
\hline & otx1/otx2 & 915 & -0.66 & & & & \\
\hline \multirow{3}{*}{212825} & $A \times 2 / A \times 1$ & 906 & -0.54 & \multirow{3}{*}{909.33} & \multirow{3}{*}{5.77} & \multirow{3}{*}{-0.53} & \multirow{3}{*}{0.02} \\
\hline & $\mathrm{BX} 2 / \mathrm{BX} 1$ & 906 & -0.51 & & & & \\
\hline & EX2/EX1 & 916 & -0.54 & & & & \\
\hline \multirow{4}{*}{132826} & $A \times 2 / A \times 1$ & 977 & -0.45 & \multirow{4}{*}{954.25} & \multirow{4}{*}{28.6} & \multirow{4}{*}{-0.48} & \multirow{4}{*}{0.09} \\
\hline & DX2/DX1 & 978 & -0.36 & & & & \\
\hline & EX2/EX1 & 921 & -0.54 & & & & \\
\hline & FX1/FX2 & 941 & -0.57 & & & & \\
\hline & & \multicolumn{2}{|c|}{ Total Average } & 937.27 & 17.20 & -0.45 & 0.07 \\
\hline
\end{tabular}


Table 13. Ghiorso and Evans (2008) Thermometry and Oxygen fugacity for 2011 eruptive event.

\begin{tabular}{|c|c|c|c|c|c|c|c|}
\hline Sample & Oxide pair & Temperature & Ox fug & Average temp & standard dev & Average Ox Fug & standard dev \\
\hline \multirow{4}{*}{ DTCCL11 } & $\mathrm{G} 1 \mathrm{~m} / \mathrm{G} 1$ & 889 & -0.69 & \multirow{4}{*}{900.75} & \multirow{4}{*}{17.6} & \multirow{4}{*}{-0.82} & \multirow{4}{*}{0.07} \\
\hline & EX3/EX2 & 902 & -0.89 & & & & \\
\hline & R1 & 942 & -0.73 & & & & \\
\hline & R4 & 870 & -0.95 & & & & \\
\hline \multirow{2}{*}{ pumice } & VSM1/VGIL1 & 874 & -0.97 & \multirow{2}{*}{875} & \multirow{2}{*}{1.41} & \multirow{2}{*}{-0.81} & \multirow{2}{*}{0.23} \\
\hline & $\mathrm{HM} / \mathrm{Hil}$ & 876 & -0.65 & & & & \\
\hline \multirow{8}{*}{ Castro et al., 2013} & A-gr22 & 922 & -0.64 & \multirow{8}{*}{892.25} & \multirow{8}{*}{-} & \multirow{8}{*}{-0.87} & \multirow{8}{*}{-} \\
\hline & A-gr33 & 897 & -0.85 & & & & \\
\hline & A-gr38 & 910 & -0.67 & & & & \\
\hline & D-gr1 & 872 & -1.03 & & & & \\
\hline & D-gr5 & 864 & -1.17 & & & & \\
\hline & F-gr1 & 878 & -0.91 & & & & \\
\hline & F-gr13 & 891 & -0.83 & & & & \\
\hline & F-gr2 & 904 & -0.85 & & & & \\
\hline & & \multicolumn{2}{|c|}{ Total Average } & 889.33 & - & -0.83 & - \\
\hline
\end{tabular}


Table 13b. Ghiorso and Evans thermometer results for discarded pairs.

\begin{tabular}{|c|c|c|c|l|}
\hline Sample & $\mathrm{T}^{\circ} \mathrm{C}$ (Fe-Ti exchange) & $\log _{10} \mathrm{f}_{\mathrm{O} 2}$ (relative to NNO) & $\mathrm{T}^{\circ} \mathrm{C}$ (Fe-Mg exchange) & \multicolumn{1}{|c|}{ Discarted reson } \\
\hline $42825-\mathrm{cx} 1 / \mathrm{cx} 2$ & 937 & -0.46 & 1206 & far away pair \\
\hline 72822-0tem/ote & 1002 & 0.07 & 1151 & inclusion cluster \\
\hline $42823 \mathrm{a}-\mathrm{C} 4 / \mathrm{C1}$ & 889 & -0.54 & -717 & test fail \\
\hline 42823a-Ex1/EX2 & 999 & -0.1 & 606 & inclusion cluster \\
\hline 42828-Bx2/Bx1 & 952 & -0.19 & 1322 & Test fail \\
132824a-Ax4/Ax3 & 911 & -0.44 & 1347 & textural desequilibiurm \\
$212823 \mathrm{~b}-\mathrm{Cx} 1 / \mathrm{Cx2}$ & 985 & -0.14 & 1261 & Test fail \\
212825-Fx2/Fx1 & 894 & -0.57 & 1234 & Test fail \\
\hline
\end{tabular}


Table 14.1921 eruptive event water calculations for Water and Lange 2015 hygrometer under average temperature per sample

\begin{tabular}{|c|c|c|c|c|c|}
\hline Sample & wt $\% \mathrm{H} 2 \mathrm{O}$ & XAn & Temperature $\left({ }^{\circ} \mathrm{C}\right)$ & MEAN & SD \\
\hline 42823a-pl-C1 & 3.17 & 0.39 & 920 & \multirow{6}{*}{3.08} & \multirow{6}{*}{0.04} \\
\hline 42823a-pl-r2 & 3.15 & 0.38 & 920 & & \\
\hline 42823a-pl-r4 & 3.16 & 0.38 & 920 & & \\
\hline 42823a-pl-r5m & 2.92 & 0.25 & 920 & & \\
\hline 42823a-pl-otm2 & 3.03 & 0.30 & 920 & & \\
\hline 42823a-pl-otm & 3.08 & 0.33 & 920 & & \\
\hline 42823b-pl-r1m & 2.41 & 0.30 & 951 & \multirow{6}{*}{2.50} & \multirow{6}{*}{0.03} \\
\hline $42823 b-p l-r 2$ & 2.56 & 0.40 & 951 & & \\
\hline $42823 b-p l-r 4 m$ & 2.56 & 0.40 & 951 & & \\
\hline 42823b-pl-r3 & 2.51 & 0.37 & 951 & & \\
\hline $42823 b-p l-r 3 m$ & 2.47 & 0.34 & 951 & & \\
\hline 42823b-pl-r4 & 2.47 & 0.34 & 951 & & \\
\hline 42825-pl-r1m-2 & 1.97 & 0.29 & 973 & \multirow{6}{*}{2.05} & \multirow{6}{*}{0.04} \\
\hline 42825-pl-r1-1 & 2.16 & 0.41 & 973 & & \\
\hline 42825-pl-r3s-2 & 2.11 & 0.38 & 973 & & \\
\hline 42825-pl-r3m-1 & 1.99 & 0.30 & 973 & & \\
\hline $42825-p l-r 5-2$ & 2.12 & 0.38 & 973 & & \\
\hline 42825-pl-r4m-3b & 1.98 & 0.29 & 973 & & \\
\hline 42828-pl-r1 & 2.52 & 0.38 & 952 & \multirow{6}{*}{2.46} & \multirow{6}{*}{0.04} \\
\hline 42828-pl-Dm & 2.38 & 0.30 & 952 & & \\
\hline 42828-pl-r2 & 2.54 & 0.40 & 952 & & \\
\hline 42828-pl-r3 & 2.48 & 0.36 & 952 & & \\
\hline 42828-pl-r4 & 2.50 & 0.37 & 952 & & \\
\hline 42828-pl-r5m & 2.35 & 0.28 & 952 & & \\
\hline 72822-plnw & 2.55 & 0.42 & 953 & \multirow{6}{*}{2.46} & \multirow{6}{*}{0.05} \\
\hline 72822-plot & 2.53 & 0.41 & 953 & & \\
\hline 72822pIr1 & 2.53 & 0.40 & 953 & & \\
\hline 72822-plsm & 2.28 & 0.26 & 953 & & \\
\hline 72822-plotm & 2.42 & 0.33 & 953 & & \\
\hline 72822-plr1m & 2.44 & 0.34 & 953 & & \\
\hline
\end{tabular}


Table 15.1960 eruptive event water calculations for Water and Lange 2015 hygrometer under average temperature per sample

\begin{tabular}{|c|c|c|c|c|c|}
\hline Sample & wt\% H2O & XAn & Temperature $\left({ }^{\circ} \mathrm{C}\right)$ & MEAN & SD \\
\hline 132824a-pl-A1 & 2.9 & 0.36 & 926 & \multirow{7}{*}{2.78} & \multirow{7}{*}{0.05} \\
\hline 132824a-pl-A2 & 2.9 & 0.35 & 926 & & \\
\hline 132824a-pl-B1* & 2.6 & 0.22 & 926 & & \\
\hline 132824a-pl-R2 & 2.8 & 0.34 & 926 & & \\
\hline 132824a-pl-C1 & 2.9 & 0.36 & 926 & & \\
\hline 132824a-pl-R5* & 2.8 & 0.33 & 926 & & \\
\hline 132824a-pl-ot* & 2.6 & 0.21 & 926 & & \\
\hline 132826-pl-r2 & 2.3 & 0.36 & 954 & \multirow{6}{*}{2.16} & \multirow{6}{*}{0.07} \\
\hline 132826-pl-r2m & 2.1 & 0.23 & 954 & & \\
\hline 132826-pl-r5 & 2.3 & 0.34 & 954 & & \\
\hline 132826-pl-r7m & 1.9 & 0.17 & 954 & & \\
\hline 132826-pl-r8 & 2.3 & 0.34 & 954 & & \\
\hline 132826-pl-r8m & 2.1 & 0.22 & 954 & & \\
\hline 132828pl-A1 & 2.8 & 0.38 & 932 & \multirow{7}{*}{2.73} & \multirow{7}{*}{0.02} \\
\hline 132828pl-r1 & 2.8 & 0.36 & 932 & & \\
\hline 132828pl-g1 & 2.8 & 0.36 & 932 & & \\
\hline 132828pl-E1* & 2.7 & 0.34 & 932 & & \\
\hline 132828pl-R5-1* & 2.7 & 0.33 & 932 & & \\
\hline 132828pl-R2b & 2.7 & 0.36 & 932 & & \\
\hline $132828 \mathrm{pl}-\mathrm{Ot} *$ & 2.6 & 0.29 & 932 & & \\
\hline 212825-pl-c1 & 3.2 & 0.37 & 909 & \multirow{6}{*}{3.14} & \multirow{6}{*}{0.05} \\
\hline 212825-pl-cm & 3.1 & 0.28 & 909 & & \\
\hline 212825-pl-r1 & 3.2 & 0.35 & 909 & & \\
\hline 212825-pl-r2m & 3.0 & 0.22 & 909 & & \\
\hline 212825-pl-r3 & 3.2 & 0.35 & 909 & & \\
\hline 212825-pl-r3m & 3.1 & 0.28 & 909 & & \\
\hline 212823b-pl-r2 & 2.1 & 0.35 & 963 & \multirow{7}{*}{2.10} & \multirow{7}{*}{0.03} \\
\hline 212823b-pl-C1 & 2.1 & 0.35 & 963 & & \\
\hline 212823b-pl-C1m & 2.0 & 0.29 & 963 & & \\
\hline 212823b-pl-C1cl & 2.2 & 0.37 & 963 & & \\
\hline 212823b-pl-Cm & 2.0 & 0.26 & 963 & & \\
\hline 212823b-pl-C1b & 2.2 & 0.37 & 963 & & \\
\hline 212823b-pl-Cm2 & 2.1 & 0.33 & 963 & & \\
\hline
\end{tabular}


Table 16. 2011 eruptive event water calculations for Water and Lange (2015) hygrometer under average temperature per sample.Blue Castro et al., (2013) values taken from Water and Lange (2015).

\begin{tabular}{|c|c|c|c|c|c|}
\hline Sample & wt\% $\mathrm{H} 2 \mathrm{O}$ & XAn & Temperature $\left({ }^{\circ} \mathrm{C}\right)$ & MEAN & SD \\
\hline dtccl11-pl-r1m & 3.2 & 0.23 & 900 & \multirow{6}{*}{3.39} & \multirow{6}{*}{0.05} \\
\hline dtccl11-pl-r2 & 3.5 & 0.36 & 900 & & \\
\hline dtccl11-pl-r2b & 3.5 & 0.36 & 900 & & \\
\hline dtccl11-pl-r3m & 3.4 & 0.30 & 900 & & \\
\hline dtccl11-pl-r5 & 3.5 & 0.35 & 900 & & \\
\hline dtccl11-pl-bm & 3.2 & 0.23 & 900 & & \\
\hline pmh-vs11-pl1 & 3.8 & 0.23 & 875 & \multirow{6}{*}{3.93} & \multirow{6}{*}{0.05} \\
\hline pmh11-pl & 4.0 & 0.36 & 875 & & \\
\hline pmh11-pl1 & 4.0 & 0.36 & 875 & & \\
\hline pmh11-pl2 & 3.9 & 0.30 & 875 & & \\
\hline pmh11-pl3 & 4.1 & 0.35 & 875 & & \\
\hline pmvs11-pl2 & 3.8 & 0.23 & 875 & & \\
\hline Puy 10 & 2.5 & 0.4 & 925 & & \\
\hline Puy 15 & 3.3 & 0.4 & 875 & & \\
\hline Puy 17 & 5.0 & 0.4 & 825 & - & - \\
\hline Puy 2 & 3.9 & 0.4 & 850 & & \\
\hline Puy 9 & 2.6 & 0.4 & 900 & & \\
\hline
\end{tabular}


Table 17. 1921 eruptive event water calculations for Water and Lange 2015 hygrometer under highest average temperature.

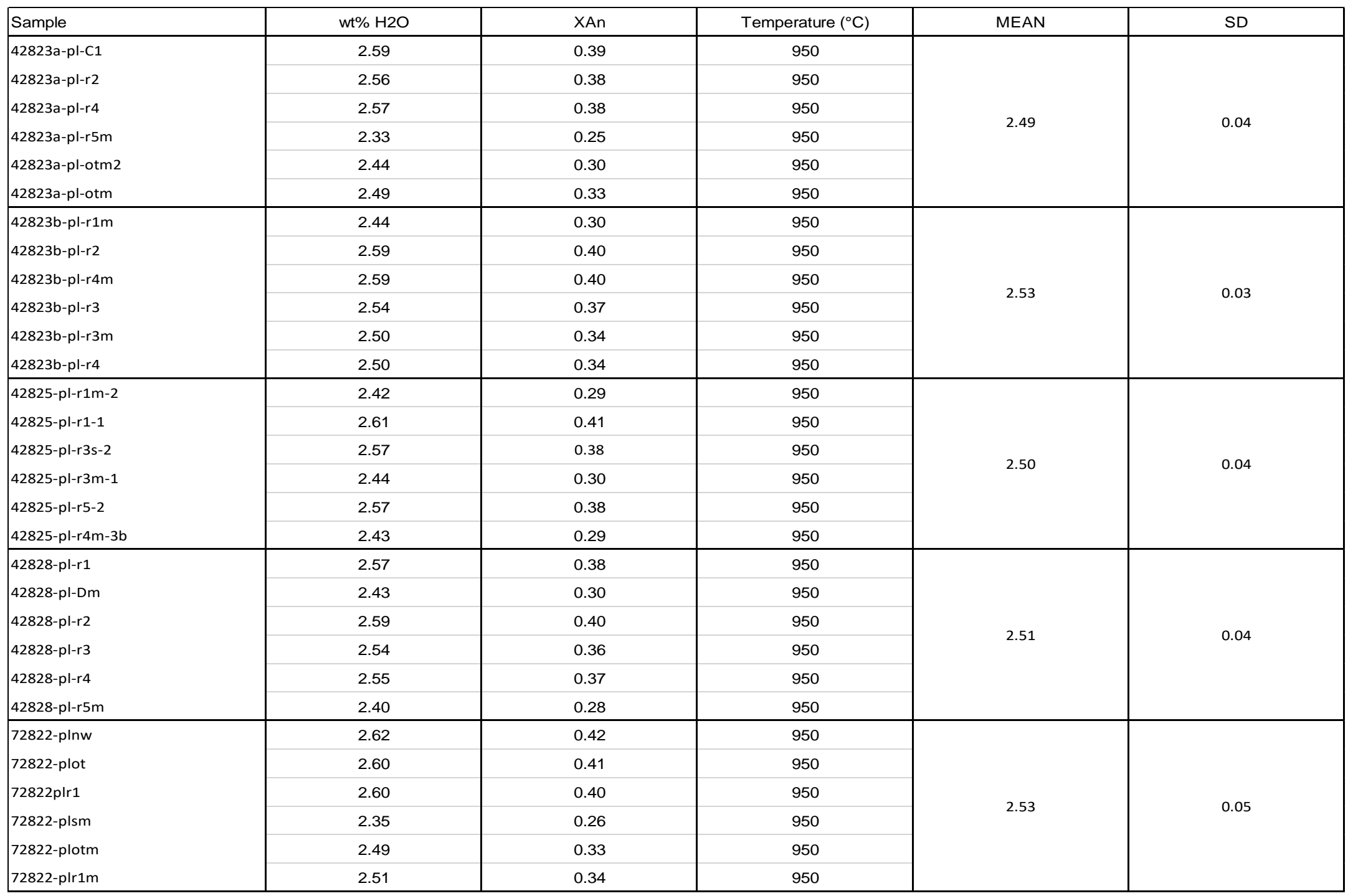


Table 18. 1960 eruptive event water calculations for Water and Evans 2015 hygrometer under highest average temperature.

\begin{tabular}{|c|c|c|c|c|c|}
\hline Sample & $\mathrm{wt} \% \mathrm{H} 2 \mathrm{O}$ & XAn & Temperature $\left({ }^{\circ} \mathrm{C}\right)$ & MEAN & SD \\
\hline 132824a-pl-A1 & 2.4 & 0.36 & 950 & \multirow{7}{*}{2.32} & \multirow{7}{*}{0.05} \\
\hline 132824a-pl-A2 & 2.4 & 0.35 & 950 & & \\
\hline 132824a-pl-B1* & 2.1 & 0.22 & 950 & & \\
\hline 132824a-pl-R2 & 2.4 & 0.34 & 950 & & \\
\hline 132824a-pl-C1 & 2.4 & 0.36 & 950 & & \\
\hline 132824a-pl-R5* & 2.4 & 0.33 & 950 & & \\
\hline 132824a-pl-ot* & 2.1 & 0.21 & 950 & & \\
\hline 132826-pl-r2 & 2.4 & 0.36 & 950 & \multirow{6}{*}{2.25} & \multirow{6}{*}{0.07} \\
\hline $132826-p l-r 2 m$ & 2.2 & 0.23 & 950 & & \\
\hline 132826-pl-r5 & 2.4 & 0.34 & 950 & & \\
\hline 132826-pl-r7m & 2.0 & 0.17 & 950 & & \\
\hline 132826-pl-r8 & 2.4 & 0.34 & 950 & & \\
\hline $132826-p l-r 8 m$ & 2.2 & 0.22 & 950 & & \\
\hline 132828pl-A1 & 2.4 & 0.38 & 950 & \multirow{7}{*}{2.39} & \multirow{7}{*}{0.02} \\
\hline 132828pl-r1 & 2.4 & 0.36 & 950 & & \\
\hline 132828pl-g1 & 2.4 & 0.36 & 950 & & \\
\hline 132828pl-E1* & 2.4 & 0.34 & 950 & & \\
\hline 132828pl-R5-1* & 2.4 & 0.33 & 950 & & \\
\hline 132828pl-R2b & 2.4 & 0.36 & 950 & & \\
\hline 132828pl-Ot* & 2.3 & 0.29 & 950 & & \\
\hline 212825-pl-c1 & 2.4 & 0.37 & 950 & \multirow{6}{*}{2.32} & \multirow{6}{*}{0.05} \\
\hline 212825-pl-cm & 2.3 & 0.28 & 950 & & \\
\hline 212825-pl-r1 & 2.4 & 0.35 & 950 & & \\
\hline 212825-pl-r2m & 2.2 & 0.22 & 950 & & \\
\hline 212825-pl-r3 & 2.4 & 0.35 & 950 & & \\
\hline 212825-pl-r3m & 2.3 & 0.28 & 950 & & \\
\hline 212823b-pl-r2 & 2.4 & 0.35 & 950 & \multirow{7}{*}{2.36} & \multirow{7}{*}{0.03} \\
\hline 212823b-pl-C1 & 2.4 & 0.35 & 950 & & \\
\hline 212823b-pl-C1m & 2.3 & 0.29 & 950 & & \\
\hline 212823b-pl-C1cl & 2.4 & 0.37 & 950 & & \\
\hline 212823b-pl-Cm & 2.2 & 0.26 & 950 & & \\
\hline 212823b-pl-C1b & 2.4 & 0.37 & 950 & & \\
\hline 212823b-pl-Cm2 & 2.4 & 0.33 & 950 & & \\
\hline
\end{tabular}


Table 19. 2011 eruptive event water calculations for Water and Lange (2015) hygrometer under highest average temperature.Blue Castro et al., (2013) measurements taken from Water and Lange.

\begin{tabular}{|c|c|c|c|c|c|}
\hline Sample & wt\% H2O & XAn & Temperature $\left({ }^{\circ} \mathrm{C}\right)$ & MEAN & SD \\
\hline dtccl11-pl-r1m & 2.2 & 0.23 & 950 & \multirow{6}{*}{2.38} & \multirow{6}{*}{0.05} \\
\hline dtccl11-pl-r2 & 2.5 & 0.36 & 950 & & \\
\hline dtccl11-pl-r2b & 2.5 & 0.36 & 950 & & \\
\hline dtccl11-pl-r3m & 2.4 & 0.30 & 950 & & \\
\hline dtccl11-pl-r5 & 2.5 & 0.35 & 950 & & \\
\hline dtccl11-pl-bm & 2.2 & 0.23 & 950 & & \\
\hline pmh-vs11-pl1 & 2.2 & 0.23 & 950 & \multirow{6}{*}{2.38} & \multirow{6}{*}{0.05} \\
\hline pmh11-pl & 2.5 & 0.36 & 950 & & \\
\hline pmh11-pl1 & 2.5 & 0.36 & 950 & & \\
\hline pmh11-pl2 & 2.4 & 0.30 & 950 & & \\
\hline pmh11-pl3 & 2.5 & 0.35 & 950 & & \\
\hline pmvs11-pl2 & 2.2 & 0.23 & 950 & & \\
\hline Puy 10 & 2.5 & 0.4 & 950 & & \\
\hline Puy 15 & 2.5 & 0.4 & 950 & & \\
\hline Puy 17 & 2.5 & 0.4 & 950 & - & - \\
\hline Puy 2 & 2.5 & 0.4 & 950 & & \\
\hline Puy 9 & 2.5 & 0.4 & 950 & & \\
\hline
\end{tabular}


Table 20. 1921 eruptive event water calculations for Water and Lange 2015 hygrometer under highest temperature per unit.

\begin{tabular}{|c|c|c|c|c|c|}
\hline Sample & wt\% H2O & XAn & Temperature $\left({ }^{\circ} \mathrm{C}\right)$ & MEAN & SD \\
\hline 42823a-pl-C1 & 2.15 & 0.39 & 973 & \multirow{6}{*}{2.05} & \multirow{6}{*}{0.04} \\
\hline 42823a-pl-r2 & 2.12 & 0.38 & 973 & & \\
\hline 42823a-pl-r4 & 2.13 & 0.38 & 973 & & \\
\hline 42823a-pl-r5m & 1.89 & 0.25 & 973 & & \\
\hline 42823a-pl-otm2 & 2.00 & 0.30 & 973 & & \\
\hline 42823a-pl-otm & 2.05 & 0.33 & 973 & & \\
\hline 42823b-pl-r1m & 2.00 & 0.30 & 973 & \multirow{6}{*}{2.09} & \multirow{6}{*}{0.03} \\
\hline 42823b-pl-r2 & 2.15 & 0.40 & 973 & & \\
\hline 42823b-pl-r4m & 2.15 & 0.40 & 973 & & \\
\hline 42823b-pl-r3 & 2.10 & 0.37 & 973 & & \\
\hline $42823 b-p l-r 3 m$ & 2.06 & 0.34 & 973 & & \\
\hline 42823b-pl-r4 & 2.06 & 0.34 & 973 & & \\
\hline 42825-pl-r1m-2 & 1.98 & 0.29 & 973 & \multirow{6}{*}{2.07} & \multirow{6}{*}{0.04} \\
\hline 42825-pl-r1-1 & 2.17 & 0.41 & 973 & & \\
\hline 42825-pl-r3s-2 & 2.13 & 0.38 & 973 & & \\
\hline $42825-p l-r 3 m-1$ & 2.00 & 0.30 & 973 & & \\
\hline $42825-\mathrm{pl}-\mathrm{r5}-2$ & 2.13 & 0.38 & 973 & & \\
\hline $42825-\mathrm{pl}-\mathrm{r} 4 \mathrm{~m}-3 \mathrm{~b}$ & 1.99 & 0.29 & 973 & & \\
\hline 42828-pl-r1 & 2.13 & 0.38 & 973 & \multirow{6}{*}{2.07} & \multirow{6}{*}{0.04} \\
\hline 42828-pl-Dm & 1.99 & 0.30 & 973 & & \\
\hline 42828-pl-r2 & 2.15 & 0.40 & 973 & & \\
\hline 42828-pl-r3 & 2.10 & 0.36 & 973 & & \\
\hline 42828-pl-r4 & 2.11 & 0.37 & 973 & & \\
\hline 42828-pl-r5m & 1.96 & 0.28 & 973 & & \\
\hline 72822-plnw & 2.18 & 0.42 & 973 & \multirow{6}{*}{2.09} & \multirow{6}{*}{0.05} \\
\hline 72822-plot & 2.16 & 0.41 & 973 & & \\
\hline 72822plr1 & 2.16 & 0.40 & 973 & & \\
\hline 72822-plsm & 1.91 & 0.26 & 973 & & \\
\hline 72822-plotm & 2.05 & 0.33 & 973 & & \\
\hline 72822-plr1m & 2.07 & 0.34 & 973 & & \\
\hline
\end{tabular}


Table 21. 1960 eruptive event water calculations for Water and Evans 2015 hygrometer under highest temperature per unit.

\begin{tabular}{|c|c|c|c|c|c|}
\hline Sample & wt\% $\mathrm{H} 2 \mathrm{O}$ & XAn & Temperature $\left({ }^{\circ} \mathrm{C}\right)$ & MEAN & SD \\
\hline 132824a-pl-A1 & 2.2 & 0.36 & 963 & \multirow{7}{*}{2.07} & \multirow{7}{*}{0.0} \\
\hline 132824a-pl-A2 & 2.1 & 0.35 & 963 & & \\
\hline 132824a-pl-B1* & 1.9 & 0.22 & 963 & & \\
\hline 132824a-pl-R2 & 2.1 & 0.34 & 963 & & \\
\hline 132824a-pl-C1 & 2.2 & 0.36 & 963 & & \\
\hline 132824a-pl-R5* & 2.1 & 0.33 & 963 & & \\
\hline 132824a-pl-ot* & 1.9 & 0.21 & 963 & & \\
\hline 132826-pl-r2 & 2.2 & 0.36 & 963 & \multirow{6}{*}{2.00} & \multirow{6}{*}{0.0} \\
\hline 132826-pl-r2m & 1.9 & 0.23 & 963 & & \\
\hline 132826-pl-r5 & 2.1 & 0.34 & 963 & & \\
\hline 132826-pl-r7m & 1.8 & 0.17 & 963 & & \\
\hline 132826-pl-r8 & 2.1 & 0.34 & 963 & & \\
\hline 132826-pl-r8m & 1.9 & 0.22 & 963 & & \\
\hline 132828pl-A1 & 2.2 & 0.38 & 963 & \multirow{7}{*}{2.14} & \multirow{7}{*}{0.0} \\
\hline 132828pl-r1 & 2.2 & 0.36 & 963 & & \\
\hline 132828pl-g1 & 2.2 & 0.36 & 963 & & \\
\hline 132828pl-E1* & 2.1 & 0.34 & 963 & & \\
\hline 132828pl-R5-1* & 2.1 & 0.33 & 963 & & \\
\hline 132828pl-R2b & 2.2 & 0.36 & 963 & & \\
\hline 132828pl-Ot* & 2.0 & 0.29 & 963 & & \\
\hline 212825-pl-c1 & 2.2 & 0.37 & 963 & \multirow{6}{*}{2.07} & \multirow{6}{*}{0.0} \\
\hline 212825-pl-cm & 2.0 & 0.28 & 963 & & \\
\hline 212825-pl-r1 & 2.1 & 0.35 & 963 & & \\
\hline $212825-p l-r 2 m$ & 1.9 & 0.22 & 963 & & \\
\hline $212825-\mathrm{pl}-\mathrm{r} 3$ & 2.1 & 0.35 & 963 & & \\
\hline 212825-pl-r3m & 2.0 & 0.28 & 963 & & \\
\hline $212823 b-p l-r 2$ & 2.1 & 0.35 & 963 & \multirow{7}{*}{2.11} & \multirow{7}{*}{0.03} \\
\hline 212823b-pl-C1 & 2.1 & 0.35 & 963 & & \\
\hline 212823b-pl-C1m & 2.0 & 0.29 & 963 & & \\
\hline 212823b-pl-C1cl & 2.2 & 0.37 & 963 & & \\
\hline $212823 \mathrm{~b}-\mathrm{pl}-\mathrm{Cm}$ & 2.0 & 0.26 & 963 & & \\
\hline 212823b-pl-C1b & 2.2 & 0.37 & 963 & & \\
\hline 212823b-pl-Cm2 & 2.1 & 0.33 & 963 & & \\
\hline
\end{tabular}


Table 22. 2011 eruptive event water calculations for Water and Lange (2015) hygrometer under highest average temperature. Blue Castro et al., (2013) measurements taken from Water and Lange.

\begin{tabular}{|c|c|c|c|c|c|}
\hline Sample & wt $\% \mathrm{H} 2 \mathrm{O}$ & XAn & Temperature $\left({ }^{\circ} \mathrm{C}\right)$ & MEAN & SD \\
\hline dtccl11-pl-r1m & 3.2 & 0.23 & 903 & \multirow{6}{*}{3.34} & \multirow{6}{*}{0.05} \\
\hline dtccl11-pl-r2 & 3.4 & 0.36 & 903 & & \\
\hline dtccl11-pl-r2b & 3.4 & 0.36 & 903 & & \\
\hline dtccl11-pl-r3m & 3.3 & 0.30 & 903 & & \\
\hline dtccl11-pl-r5 & 3.5 & 0.35 & 903 & & \\
\hline dtccl11-pl-bm & 3.2 & 0.23 & 903 & & \\
\hline pmh-vs11-pl1 & 3.2 & 0.23 & 903 & \multirow{6}{*}{3.34} & \multirow{6}{*}{0.05} \\
\hline pmh11-pl & 3.4 & 0.36 & 903 & & \\
\hline pmh11-pl1 & 3.4 & 0.36 & 903 & & \\
\hline pmh11-pl2 & 3.3 & 0.30 & 903 & & \\
\hline pmh11-pl3 & 3.5 & 0.35 & 903 & & \\
\hline pmvs11-pl2 & 3.2 & 0.23 & 903 & & \\
\hline Puy 10 & 3.0 & 0.4 & 925 & & \\
\hline Puy 15 & 3.0 & 0.4 & 925 & & \\
\hline Puy 17 & 3.0 & 0.4 & 925 & - & - \\
\hline Puy 2 & 3.0 & 0.4 & 925 & & \\
\hline Puy 9 & 3.0 & 0.4 & 925 & & \\
\hline
\end{tabular}


Table 23. 1921 eruptive event water calculations for Water and Lange 2015 hygrometer under average temperature per unit.

\begin{tabular}{|c|c|c|c|c|c|}
\hline Sample & wt\% H2O & XAn & Temperature $\left({ }^{\circ} \mathrm{C}\right)$ & MEAN & SD \\
\hline 42823a-pl-C1 & 2.59 & 0.39 & 950 & \multirow{6}{*}{2.49} & \multirow{6}{*}{0.04} \\
\hline 42823a-pl-r2 & 2.56 & 0.38 & 950 & & \\
\hline 42823a-pl-r4 & 2.57 & 0.38 & 950 & & \\
\hline 42823a-pl-r5m & 2.33 & 0.25 & 950 & & \\
\hline 42823a-pl-otm2 & 2.44 & 0.30 & 950 & & \\
\hline 42823a-pl-otm & 2.49 & 0.33 & 950 & & \\
\hline 42823b-pl-r $1 \mathrm{~m}$ & 2.44 & 0.30 & 950 & \multirow{6}{*}{2.53} & \multirow{6}{*}{0.03} \\
\hline $42823 b-p l-r 2$ & 2.59 & 0.40 & 950 & & \\
\hline 42823b-pl-r4m & 2.59 & 0.40 & 950 & & \\
\hline $42823 b-p l-r 3$ & 2.54 & 0.37 & 950 & & \\
\hline 42823b-pl-r3m & 2.50 & 0.34 & 950 & & \\
\hline $42823 b-p l-r 4$ & 2.50 & 0.34 & 950 & & \\
\hline 42825-pl-r1m-2 & 2.42 & 0.29 & 950 & \multirow{6}{*}{2.50} & \multirow{6}{*}{0.04} \\
\hline 42825-pl-r1-1 & 2.61 & 0.41 & 950 & & \\
\hline 42825-pl-r3s-2 & 2.57 & 0.38 & 950 & & \\
\hline $42825-p l-r 3 m-1$ & 2.44 & 0.30 & 950 & & \\
\hline $42825-\mathrm{pl}-\mathrm{r} 5-2$ & 2.57 & 0.38 & 950 & & \\
\hline $42825-\mathrm{pl}-\mathrm{r} 4 \mathrm{~m}-3 \mathrm{~b}$ & 2.43 & 0.29 & 950 & & \\
\hline 42828-pl-r1 & 2.57 & 0.38 & 950 & \multirow{6}{*}{2.51} & \multirow{6}{*}{0.04} \\
\hline 42828-pl-Dm & 2.43 & 0.30 & 950 & & \\
\hline 42828-pl-r2 & 2.59 & 0.40 & 950 & & \\
\hline 42828-pl-r3 & 2.54 & 0.36 & 950 & & \\
\hline 42828-pl-r4 & 2.55 & 0.37 & 950 & & \\
\hline 42828-pl-r5m & 2.40 & 0.28 & 950 & & \\
\hline 72822-plnw & 2.62 & 0.42 & 950 & \multirow{6}{*}{2.53} & \multirow{6}{*}{0.05} \\
\hline 72822-plot & 2.60 & 0.41 & 950 & & \\
\hline 72822plr1 & 2.60 & 0.40 & 950 & & \\
\hline 72822-plsm & 2.35 & 0.26 & 950 & & \\
\hline 72822-plotm & 2.49 & 0.33 & 950 & & \\
\hline 72822-plr1m & 2.51 & 0.34 & 950 & & \\
\hline
\end{tabular}


Table 24. 1960 eruptive event water calculations for Water and Lange 2015 hygrometer under average temperature per unit.

\begin{tabular}{|c|c|c|c|c|c|}
\hline Sample & wt\% H2O & XAn & Temperature $\left({ }^{\circ} \mathrm{C}\right)$ & MEAN & SD \\
\hline 132824a-pl-A1 & 2.6 & 0.36 & 940 & \multirow{7}{*}{2.51} & \multirow{7}{*}{0.0} \\
\hline 132824a-pl-A2 & 2.6 & 0.35 & 940 & & \\
\hline 132824a-pl-B1* & 2.3 & 0.22 & 940 & & \\
\hline 132824a-pl-R2 & 2.6 & 0.34 & 940 & & \\
\hline 132824a-pl-C1 & 2.6 & 0.36 & 940 & & \\
\hline 132824a-pl-R5* & 2.6 & 0.33 & 940 & & \\
\hline 132824a-pl-ot* & 2.3 & 0.21 & 940 & & \\
\hline 132826-pl-r2 & 2.6 & 0.36 & 940 & \multirow{6}{*}{2.45} & \multirow{6}{*}{0.07} \\
\hline 132826-pl-r2m & 2.4 & 0.23 & 940 & & \\
\hline 132826-pl-r5 & 2.6 & 0.34 & 940 & & \\
\hline 132826-pl-r7m & 2.2 & 0.17 & 940 & & \\
\hline 132826-pl-r8 & 2.6 & 0.34 & 940 & & \\
\hline 132826-pl-r8m & 2.4 & 0.22 & 940 & & \\
\hline 132828pl-A1 & 2.6 & 0.38 & 940 & \multirow{7}{*}{2.59} & \multirow{7}{*}{0.02} \\
\hline 132828pl-r1 & 2.6 & 0.36 & 940 & & \\
\hline 132828pl-g1 & 2.6 & 0.36 & 940 & & \\
\hline 132828pl-E1* & 2.6 & 0.34 & 940 & & \\
\hline 132828pl-R5-1* & 2.6 & 0.33 & 940 & & \\
\hline 132828pl-R2b & 2.6 & 0.36 & 940 & & \\
\hline 132828pl-Ot* & 2.5 & 0.29 & 940 & & \\
\hline 212825-pl-c1 & 2.6 & 0.37 & 940 & \multirow{6}{*}{2.52} & \multirow{6}{*}{0.05} \\
\hline 212825-pl-cm & 2.5 & 0.28 & 940 & & \\
\hline 212825-pl-r1 & 2.6 & 0.35 & 940 & & \\
\hline 212825-pl-r2m & 2.4 & 0.22 & 940 & & \\
\hline 212825-pl-r3 & 2.6 & 0.35 & 940 & & \\
\hline 212825-pl-r3m & 2.5 & 0.28 & 940 & & \\
\hline 212823b-pl-r2 & 2.6 & 0.35 & 940 & \multirow{7}{*}{2.56} & \multirow{7}{*}{0.03} \\
\hline 212823b-pl-C1 & 2.6 & 0.35 & 940 & & \\
\hline 212823b-pl-C1m & 2.5 & 0.29 & 940 & & \\
\hline 212823b-pl-C1cl & 2.6 & 0.37 & 940 & & \\
\hline 212823b-pl-Cm & 2.4 & 0.26 & 940 & & \\
\hline 212823b-pl-C1b & 2.6 & 0.37 & 940 & & \\
\hline 212823b-pl-Cm2 & 2.6 & 0.33 & 940 & & \\
\hline
\end{tabular}


Table 25. 2011 eruptive event water calculations for Water and Lange (2015) hygrometer under average temperature per unit. Blue Castro et al., (2013) measurements taken from Water and Lange.

\begin{tabular}{|c|c|c|c|c|c|}
\hline Sample & wt\% H2O & XAn & Temperature $\left({ }^{\circ} \mathrm{C}\right)$ & MEAN & SD \\
\hline dtccl11-pl-r1m & 3.5 & 0.23 & 890 & \multirow{6}{*}{3.62} & \multirow{6}{*}{0.05} \\
\hline dtccl11-pl-r2 & 3.7 & 0.36 & 890 & & \\
\hline dtccl11-pl-r2b & 3.7 & 0.36 & 890 & & \\
\hline dtccl11-pl-r3m & 3.6 & 0.30 & 890 & & \\
\hline dtccl11-pl-r5 & 3.7 & 0.35 & 890 & & \\
\hline dtccl11-pl-bm & 3.5 & 0.23 & 890 & & \\
\hline pmh-vs11-pl1 & 3.5 & 0.23 & 890 & \multirow{6}{*}{3.62} & \multirow{6}{*}{0.05} \\
\hline pmh11-pl & 3.7 & 0.36 & 890 & & \\
\hline pmh11-pl1 & 3.7 & 0.36 & 890 & & \\
\hline pmh11-pl2 & 3.6 & 0.30 & 890 & & \\
\hline pmh11-pl3 & 3.7 & 0.35 & 890 & & \\
\hline pmvs11-pl2 & 3.5 & 0.23 & 890 & & \\
\hline Puy 10 & 3.7 & 0.4 & 890 & \multirow{5}{*}{-} & \multirow{5}{*}{ - } \\
\hline Puy 15 & 3.7 & 0.4 & 890 & & \\
\hline Puy 17 & 3.7 & 0.4 & 890 & & \\
\hline Puy 2 & 3.7 & 0.4 & 890 & & \\
\hline Puy 9 & 3.8 & 0.4 & 890 & & \\
\hline
\end{tabular}


Table 26. Petrography of 1921 samples.

\begin{tabular}{|l|l|l|l|}
\hline Sample & $\begin{array}{l}\text { Texture } \\
\text { group }\end{array}$ & & \multicolumn{1}{c|}{ Description } \\
\hline 42825 & TG1 & $\begin{array}{l}\text { Vitrophyric rock with approximately } 5 \% \text { of phenocrysts, that are } \\
\text { isolated in the groundmass or in rare occasions in clusters that have } \\
\text { all the mineral phases. The ground mass has hyalopilitic texture whit } \\
\text { flow bands marked by density of the glass (eutaxitic). The } \\
\text { phenocrysts mineral phases are PI + Cpx +Opx +Mg +ill +- (Ap, Zr). PI is } \\
\text { the most abundant phase with a 10:1 ratio relative to the mafic } \\
\text { crystals, they are euhedral with polysynthetic twining and sometimes } \\
\text { zoned. The size average is 0.5 to 1mm with grains that reach over } \\
\text { 2mm in the clusters. both Opx and Cpx of euhedral to subhedral } \\
\text { habits and tabular shapes, the Cpx is slightly dominant in proportion } \\
\text { and sometimes has reaction borders. The size average of Cpx is } \\
\text { 0.25mm and up to 1mm in clusters. And for the Opx is smaller size of } \\
\text { 0.1mm }\end{array}$ \\
\hline
\end{tabular}




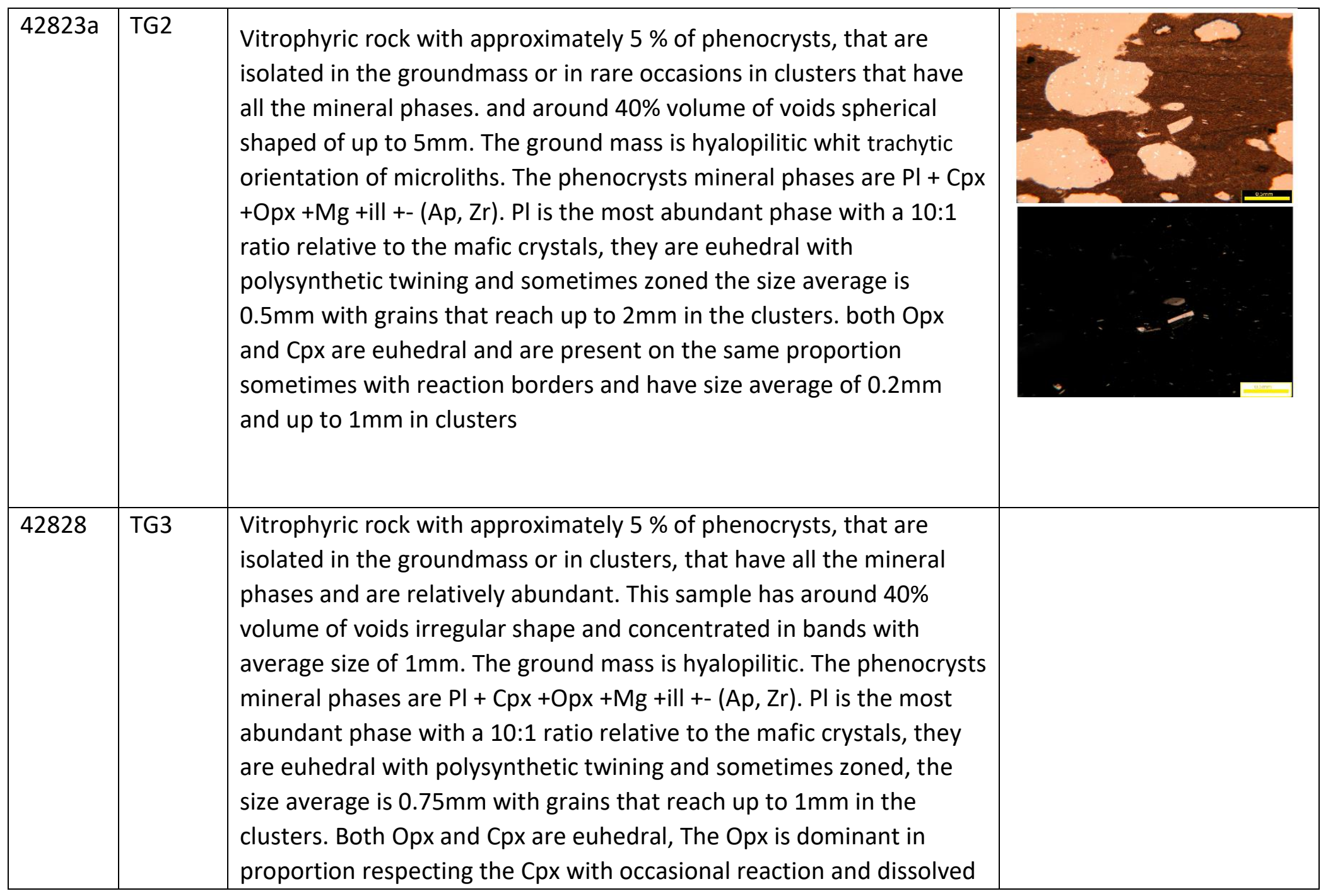




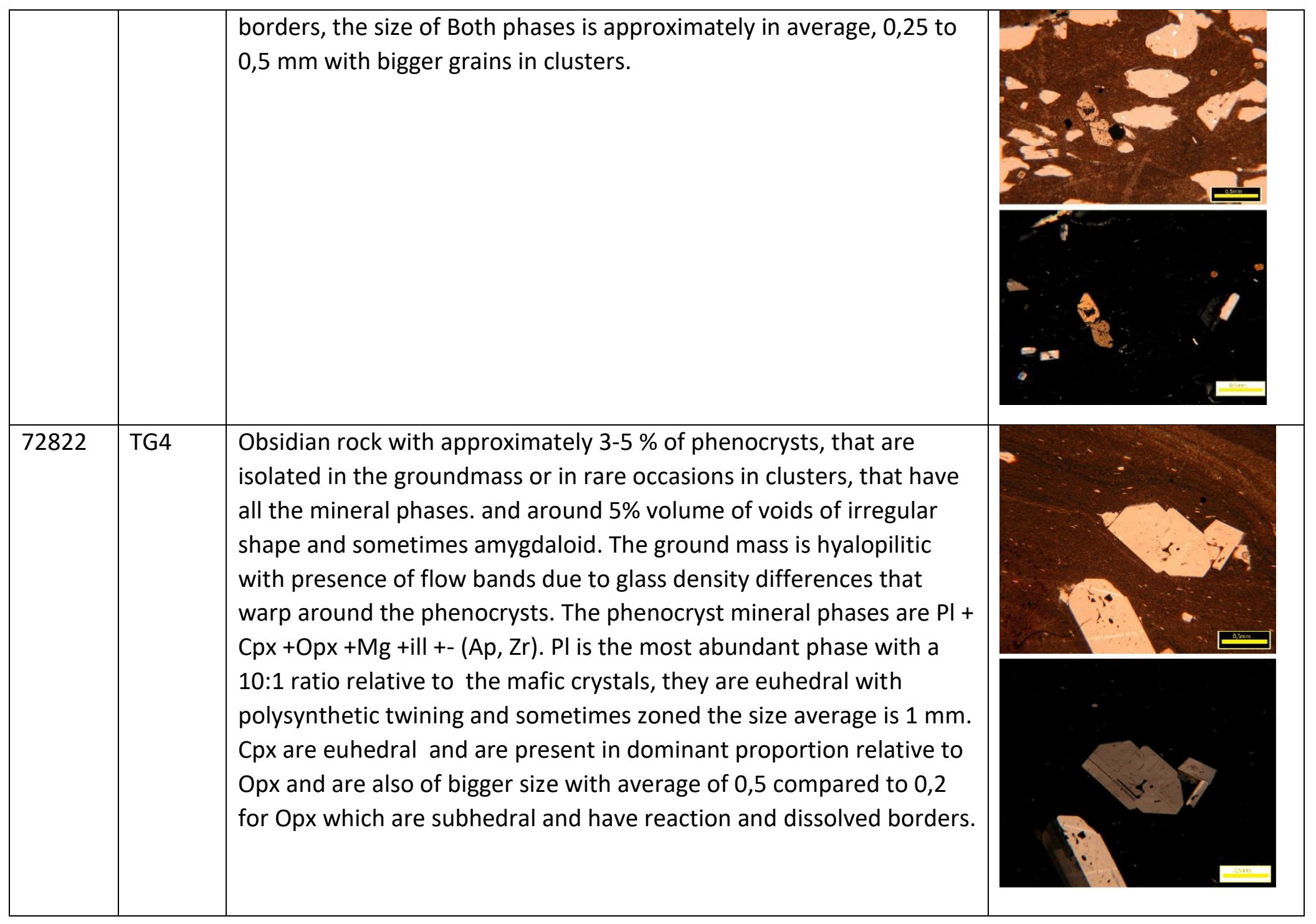




\begin{tabular}{|l|l|l|}
\hline 42823b & TG4 & $\begin{array}{l}\text { Obsidian rock with approximately } 10 \% \text { of phenocrysts, that are } \\
\text { isolated in the groundmass or in clusters making the rock almost } \\
\text { glomeroporphiric. There are spherical shape voids very isolated and } \\
\text { in less than 1\% volume. The ground mass is hyalopilitic whit trachytic } \\
\text { orientation of microliths. The phenocrysts mineral phases are } \mathrm{PI}+\mathrm{Cpx} \\
\text { +Opx +Mg +ill +- (Ap, Zr). Pl is the most abundant phase with a } 10: 1 \\
\text { ratio relative to the mafic crystals, they are euhedral with } \\
\text { polysynthetic twining and sometimes zoned the size average is } \\
0.75 \mathrm{~mm} \text {. both Opx and Cpx are euhedral and are present borders of } \\
\text { reaction with Cpx also having dissolved border, this phase is more } \\
\text { abundant and bigger in size with average of } 0.5 \mathrm{~mm} \text { compared to } \\
0.25 \text { for the Opx. }\end{array}$ \\
\hline
\end{tabular}


Table 27. Petrography of 1960 samples.

\begin{tabular}{|c|c|l|}
\hline Sample & $\begin{array}{c}\text { Texture } \\
\text { group }\end{array}$ & \multicolumn{1}{|c|}{ Description } \\
\hline 132824a & TG1 & $\begin{array}{l}\text { Vitrophyric rock with approximately 5-7 \% of phenocrysts, that are } \\
\text { isolated in the groundmass in clusters that have all the mineral } \\
\text { phases. The ground mass has hyalopilitic texture. The phenocrysts } \\
\text { mineral phases are } \mathrm{Pl}+\mathrm{Cpx}+\mathrm{Opx}+\mathrm{Mg}+\mathrm{ill}+- \text { (Ap, Zr). PI is the most } \\
\text { abundant phase with a 10:1 ratio relative to the mafic crystals, they } \\
\text { are euhedral with polysynthetic twining and sometimes zoned. The } \\
\text { size average is 0.5 to 1mm with grains that reach up to 5mm in the } \\
\text { clusters. both Opx and Cpx of euhedral to subhedral habits and } \\
\text { tabular shapes, the Cpx is slightly dominant in proportion and } \\
\text { sometimes has reaction borders. The size average, for both Pxphases } \\
\text { is around 0,5-0,2 } \mathrm{mm} .\end{array}$ \\
\hline
\end{tabular}




\begin{tabular}{|l|l|l|}
\hline 32826 & $\begin{array}{l}\text { Vitrophyric rock with approximately } 3-5 \% \text { of phenocrysts, that are } \\
\text { isolated in the groundmass or in rare occasions in clusters that have } \\
\text { all the mineral phases. and around } 30 \% \text { volume of voids spherical } \\
\text { shaped of up to } 5 \mathrm{~mm} \text {. The ground mass is hyalopilitic. The } \\
\text { phenocrysts mineral phases are } \mathrm{Pl}+\mathrm{Cpx}+\mathrm{Opx}+\mathrm{Mg}+\mathrm{ill}+-(\mathrm{Ap}, \mathrm{Zr}) . \mathrm{PI} \\
\text { is the most abundant phase with a } 10: 1 \text { ratio relative to the mafic } \\
\text { crystals, they are euhedral with polysynthetic twining and sometimes } \\
\text { zoned the size average is } 0.5 \mathrm{~mm} \text { with grains that reach up to } 2 \mathrm{~mm} \text { in } \\
\text { the clusters. both Opx and Cpx are euhedral and are present on the } \\
\text { same proportion and both have an average size of } 0.2 \mathrm{~mm} \text { and can } \\
\text { reach up to } 1 \mathrm{~mm} \text { in clusters. Reaction borders are present in Cpx. }\end{array}$ \\
\hline
\end{tabular}




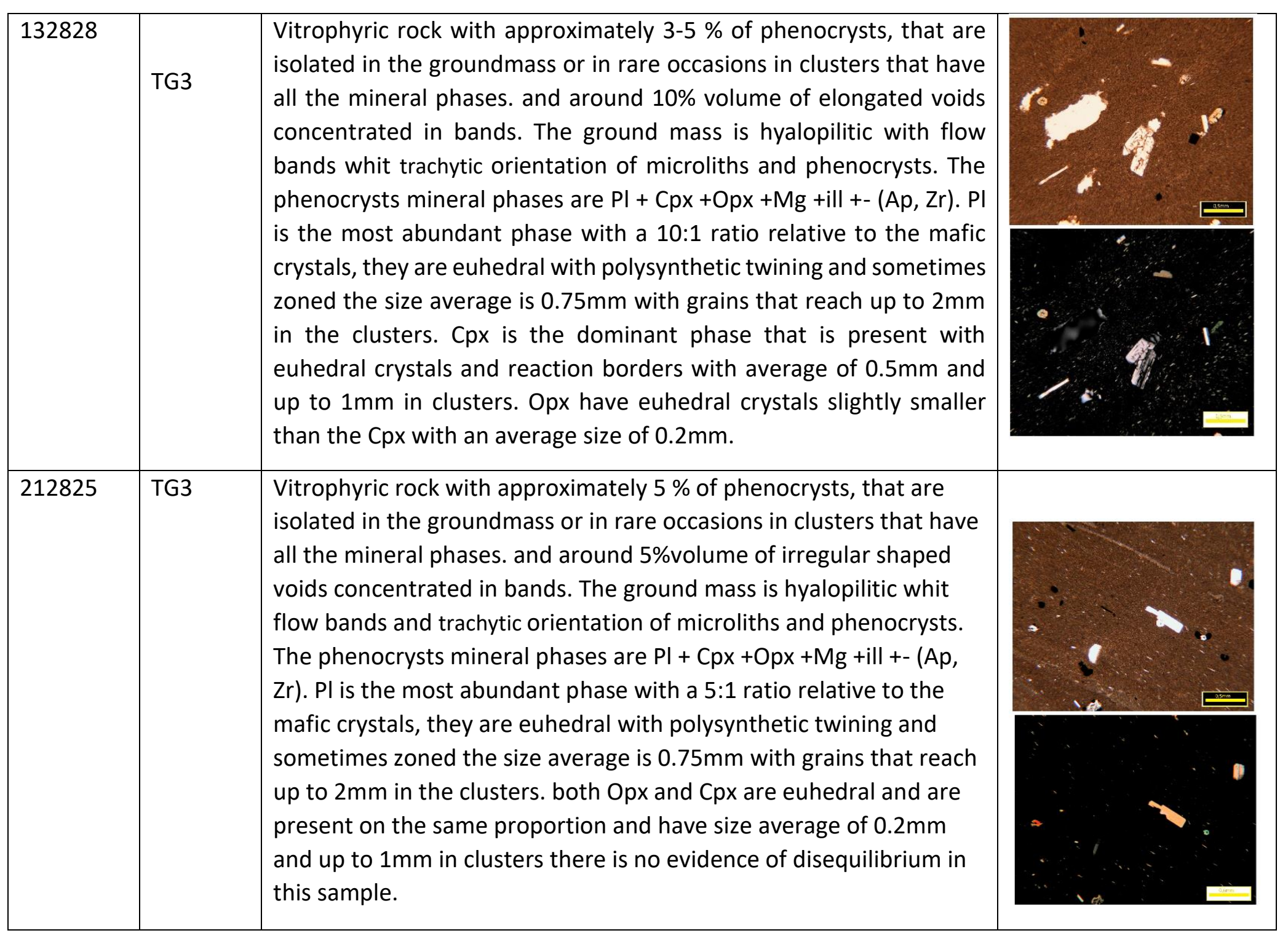




\begin{tabular}{|l|l|l|}
\hline 212823b & TG4 & $\begin{array}{l}\text { Obsidian rock with approximately 7-10 \% of phenocrysts, that are } \\
\text { isolated in the groundmass or in rare occasions in clusters, that have } \\
\text { all the mineral phases. and around 5\% volume of voids of irregular } \\
\text { shape and sometimes amygdaloid. The ground mass is hyalopilitic } \\
\text { with presence of flow bands due to glass density differences that } \\
\text { warp around the phenocrysts. The phenocryst mineral phases are } \mathrm{PI} \\
+\mathrm{Cpx}+\mathrm{Opx}+\mathrm{Mg}+\mathrm{ill}+\mathrm{Ap}, \mathrm{Zr}) \mathrm{Pl} \text { is the most abundant phase with } \\
\text { approximately 5:1 ratio relative to the mafic crystals, they are } \\
\text { euhedral with polysynthetic twining and sometimes zoned the size } \\
\text { average is 0,5 mm. both Opx and Cpx are euhedral and are present } \\
\text { on the same proportion and both have reaction and dissolved } \\
\text { borders. The size average of } 0.5 \mathrm{~mm} \text { for Cpx and 0,2mm for Opx. }\end{array}$ \\
\hline
\end{tabular}


Table 28. Petrography of 2011 lava sample.

\begin{tabular}{|c|c|c|c|}
\hline DTCCL11 & TG3 & $\begin{array}{l}\text { Vitrophyric rock with approximately } 7-10 \% \text { of phenocrysts, } \\
\text { that are isolated in the groundmass or in rare occasions in } \\
\text { clusters that have all the mineral phases. and around } 50 \% \\
\text { volume of voids irregular shaped and concentrated in bands } \\
\text { and sometimes amygdaloid filled with pl. The ground mass is } \\
\text { hyalopilitic whit trachytic orientation of microliths. The } \\
\text { phenocrysts mineral phases are } \mathrm{PI}+\mathrm{Cpx}+\mathrm{Opx}+\mathrm{Mg}+\mathrm{ill}+- \text { (Ap, } \\
\mathrm{Zr} \text { ). Pl is the most abundant phase with a } 10: 1 \text { ratio relative to } \\
\text { the mafic crystals, they are euhedral with polysynthetic } \\
\text { twining and sometimes zoned the size average is } 0.75 \mathrm{~mm} \\
\text { with grains. both Opx and Cpx are euhedral and are present } \\
\text { on the same proportion sometimes with reaction borders. } \\
\text { the average size of Cpx is about } 0.5 \mathrm{~mm} \text { and the Opx is much } \\
\text { smaller of around } 0.1 \mathrm{~mm} \text {. }\end{array}$ & $a^{-\infty}$ \\
\hline
\end{tabular}




\section{IMAGES}

Texture group 1 hand specimen

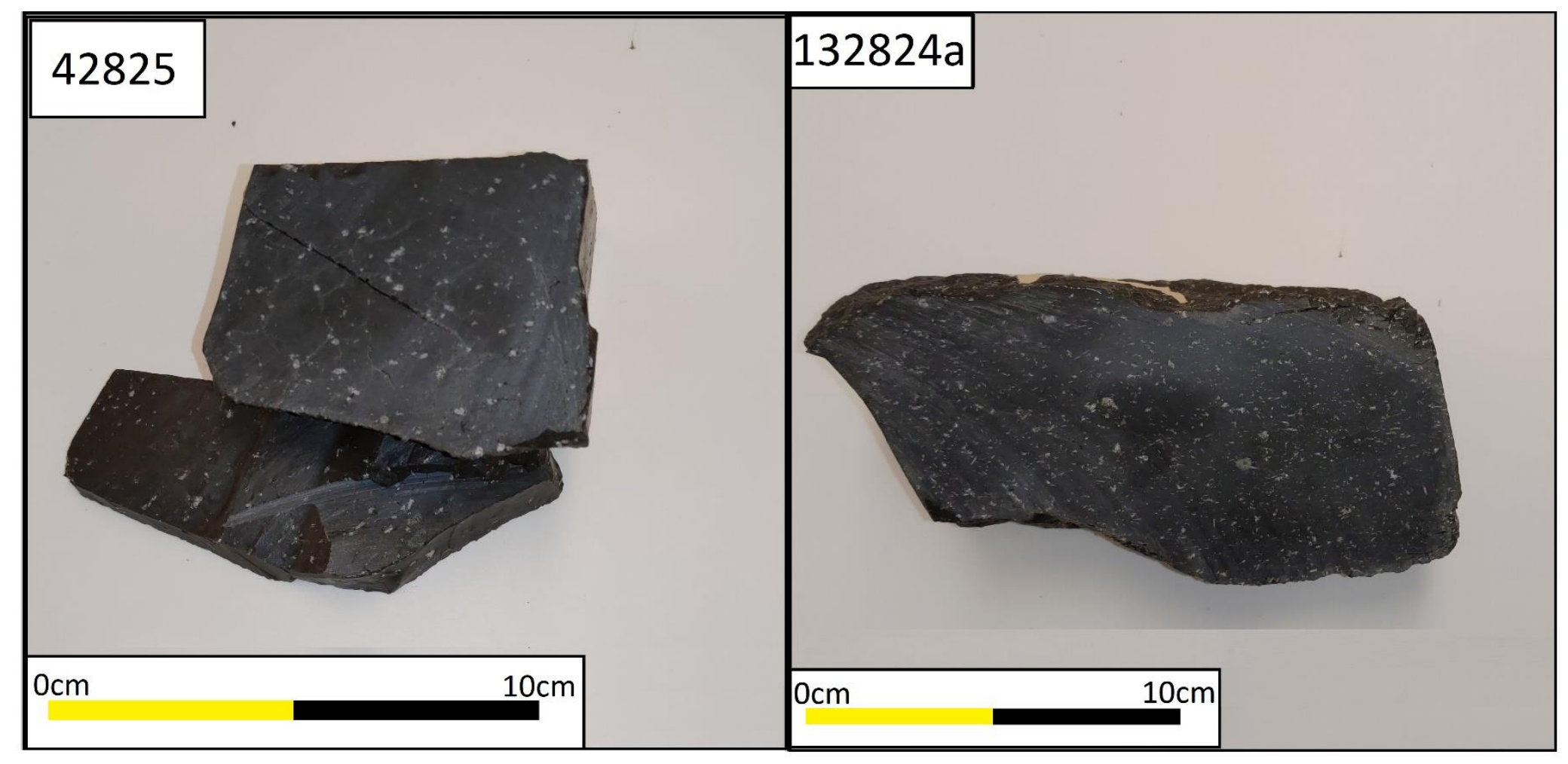


Texture Group 2 


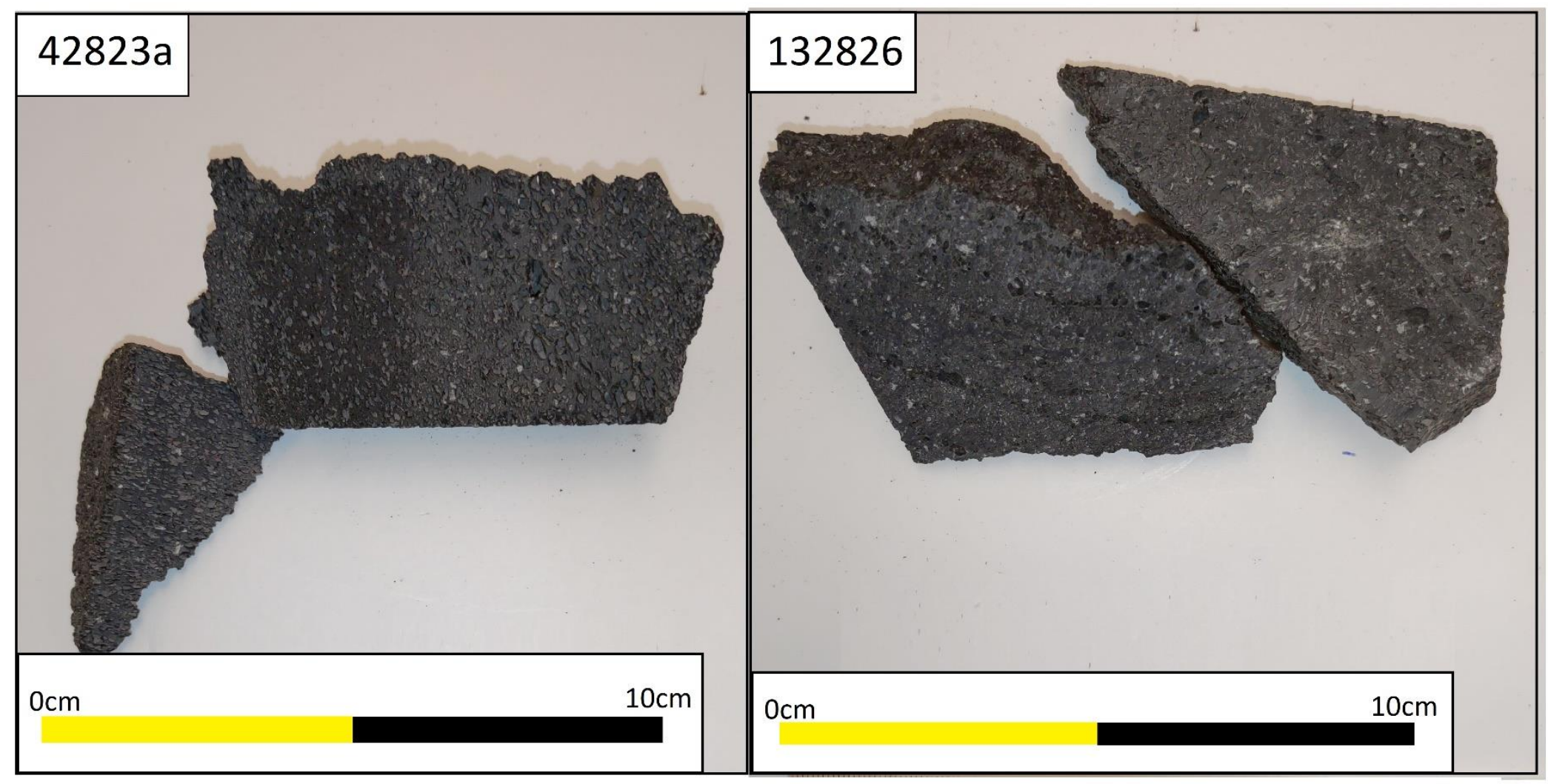


Texture group 3

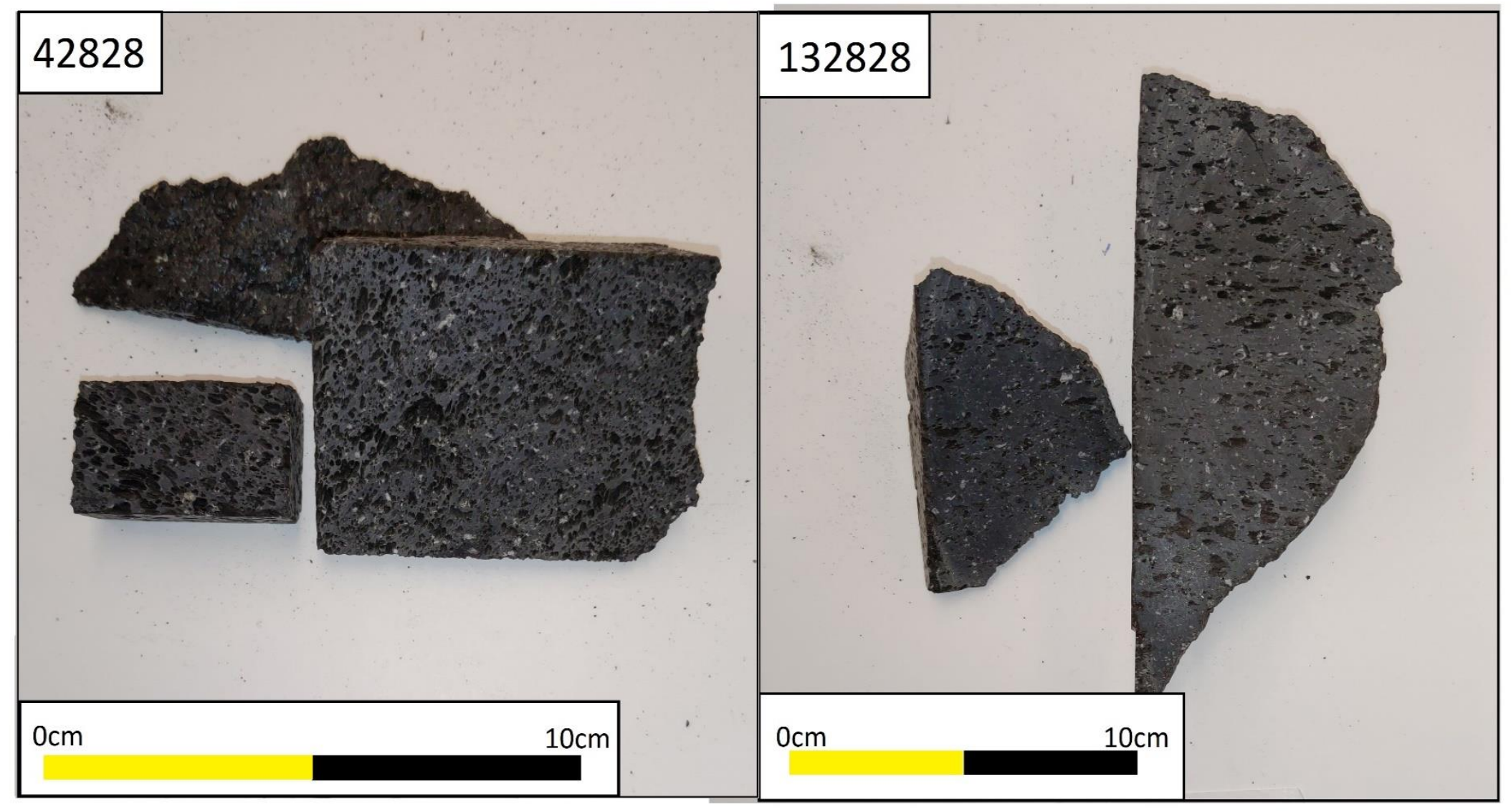




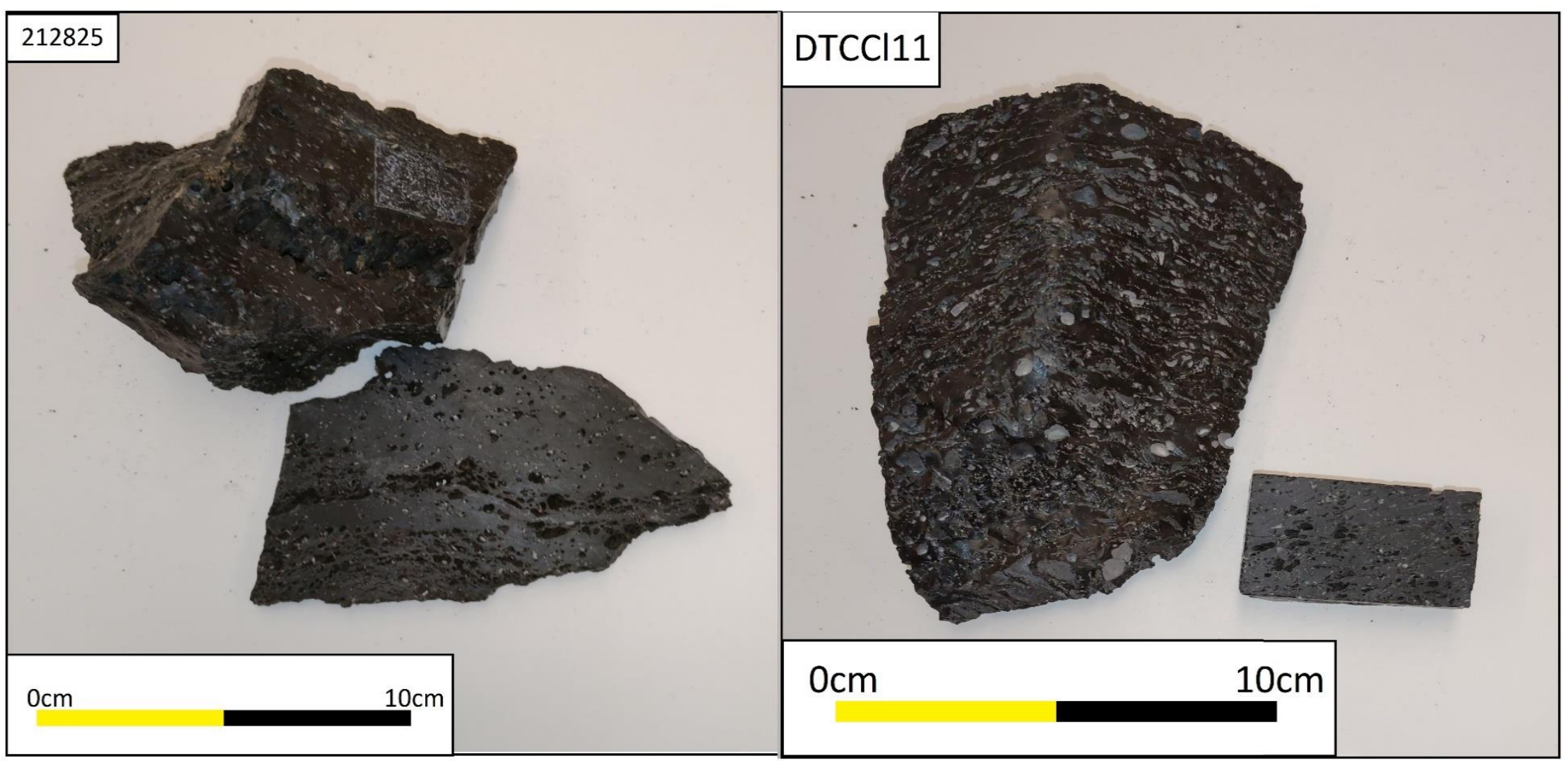


Texture group 4

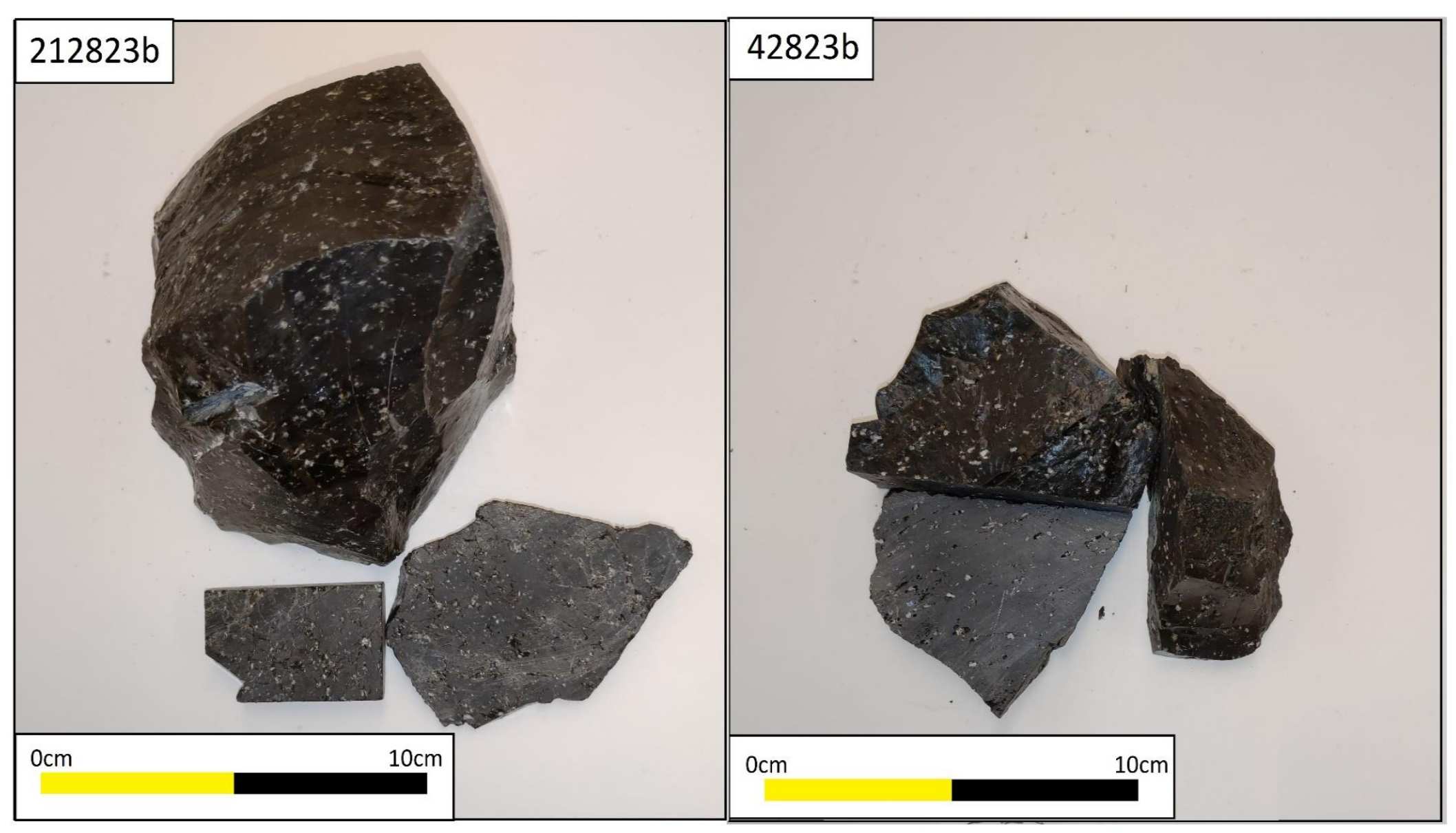


EMPA 1921 oxide pairs images

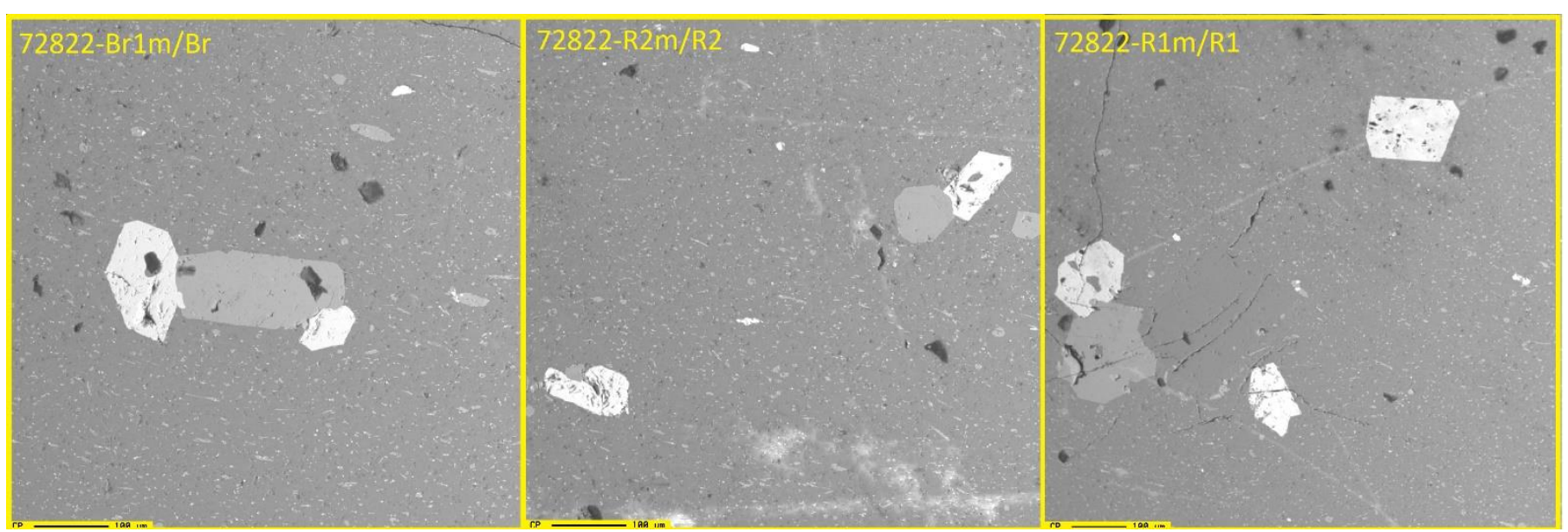




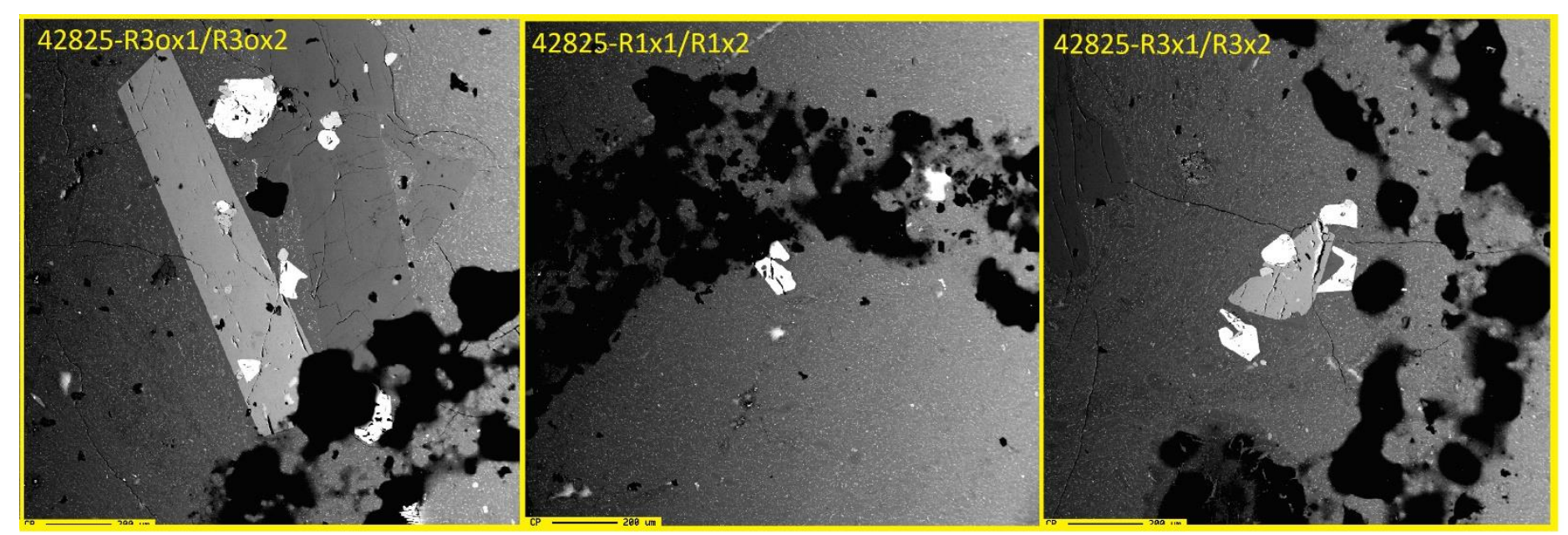




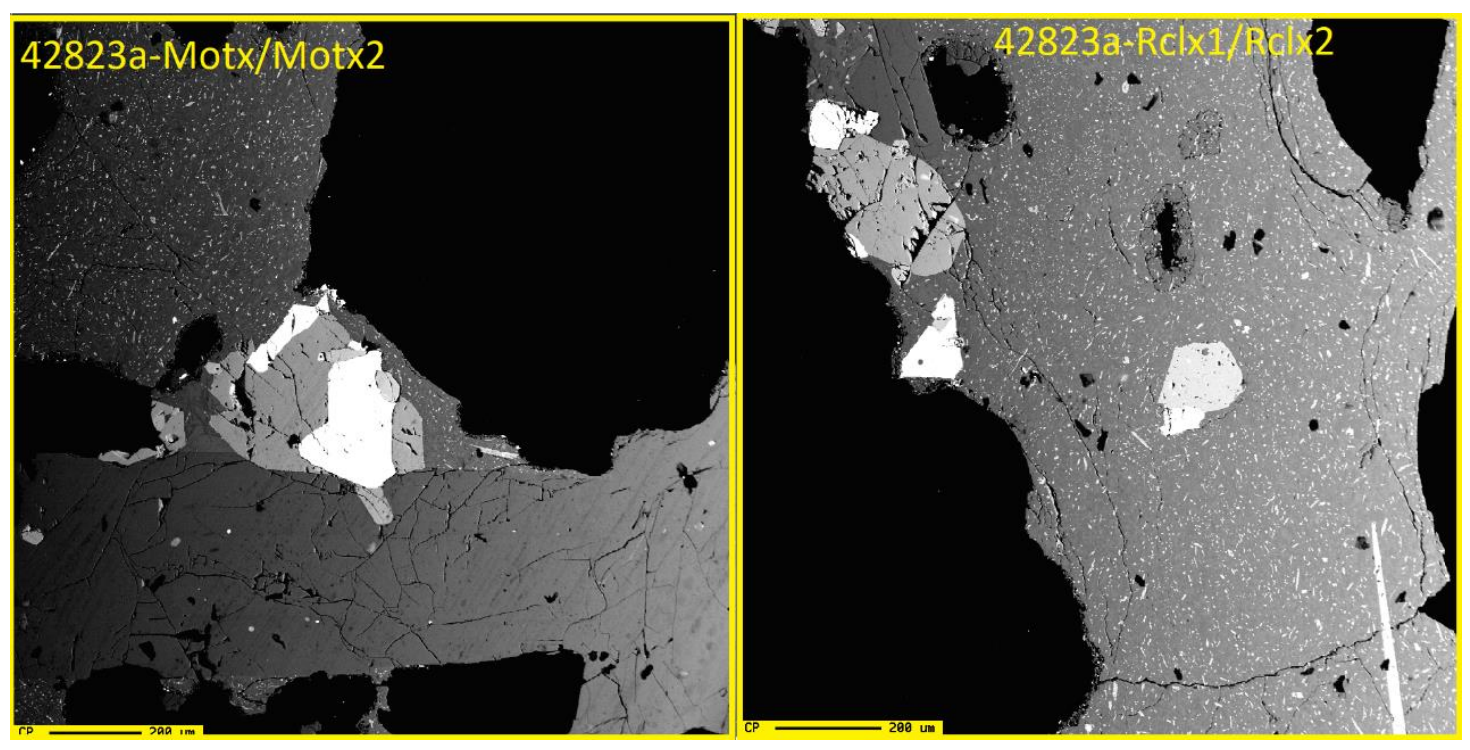




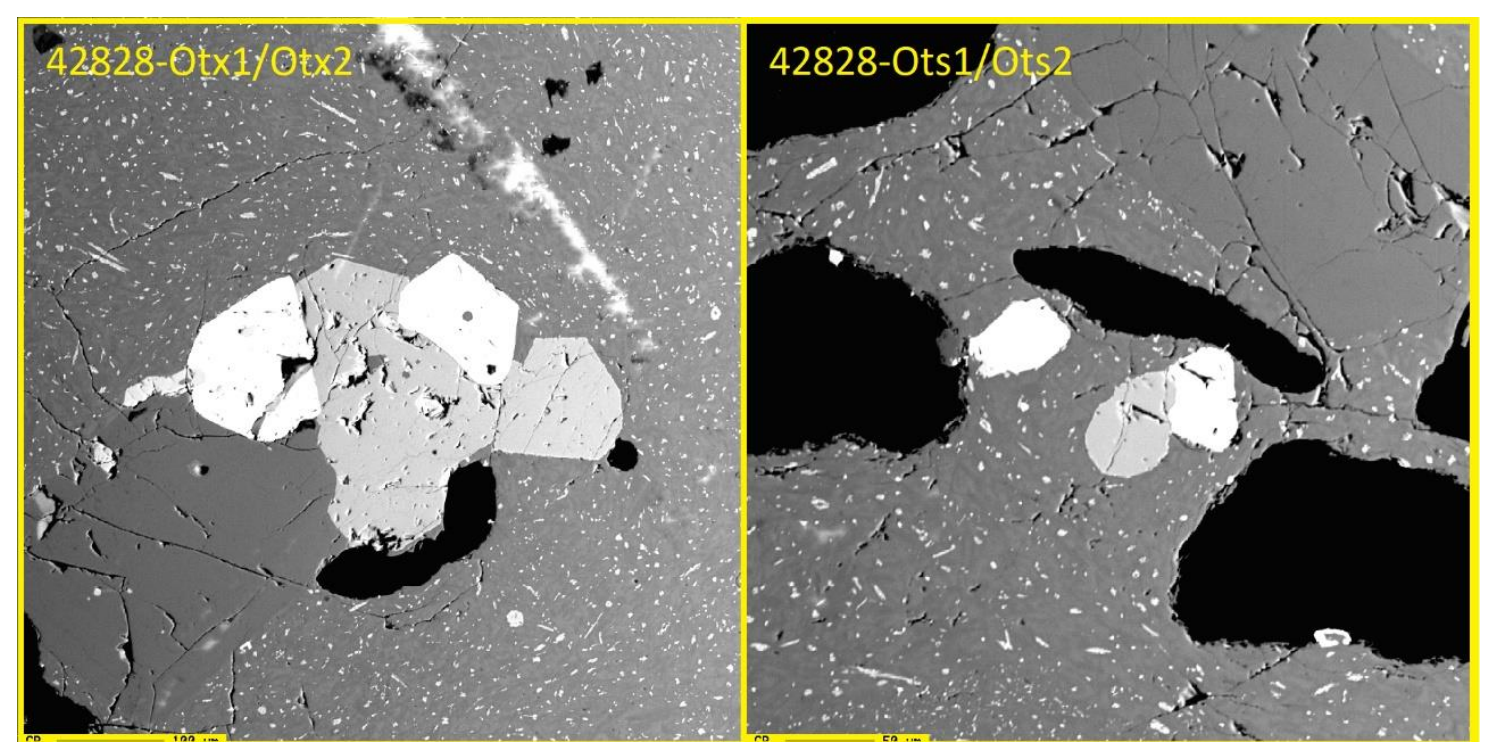


SEM 1921 Oxides pair images

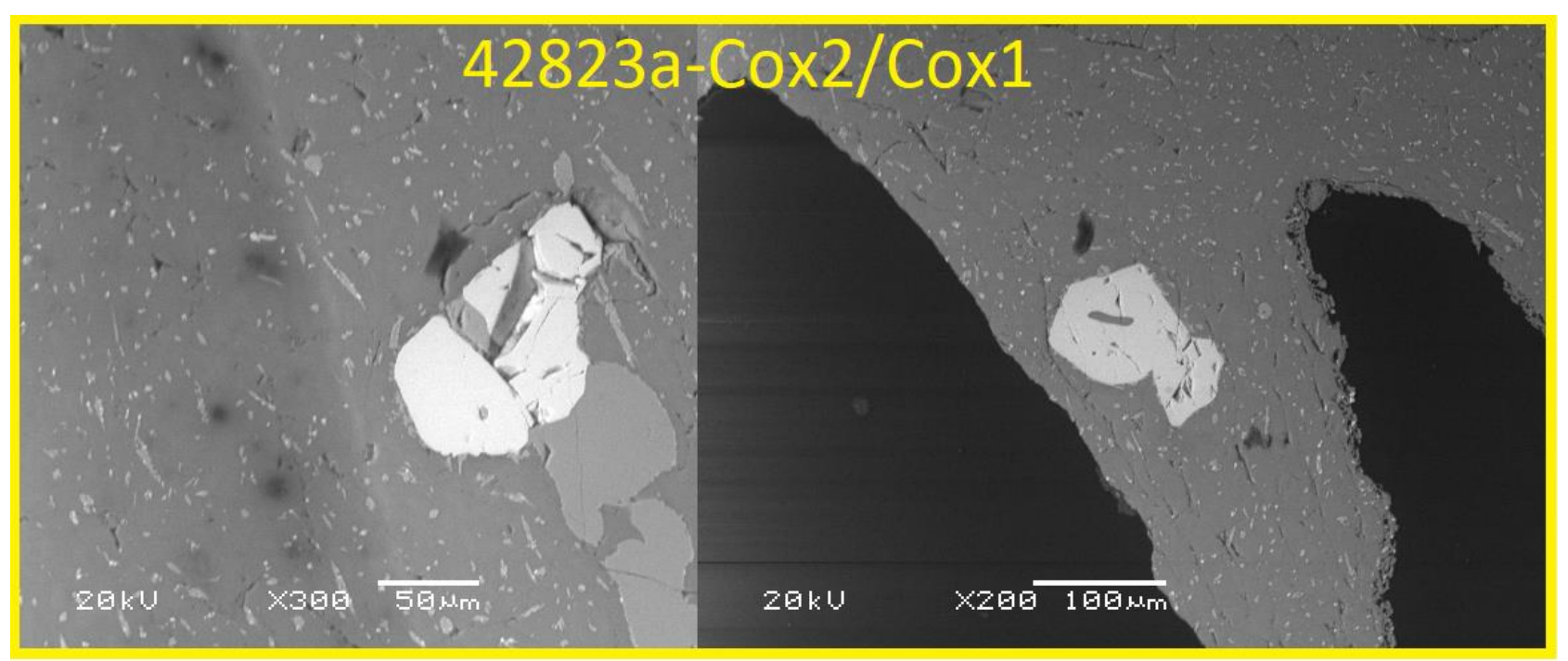




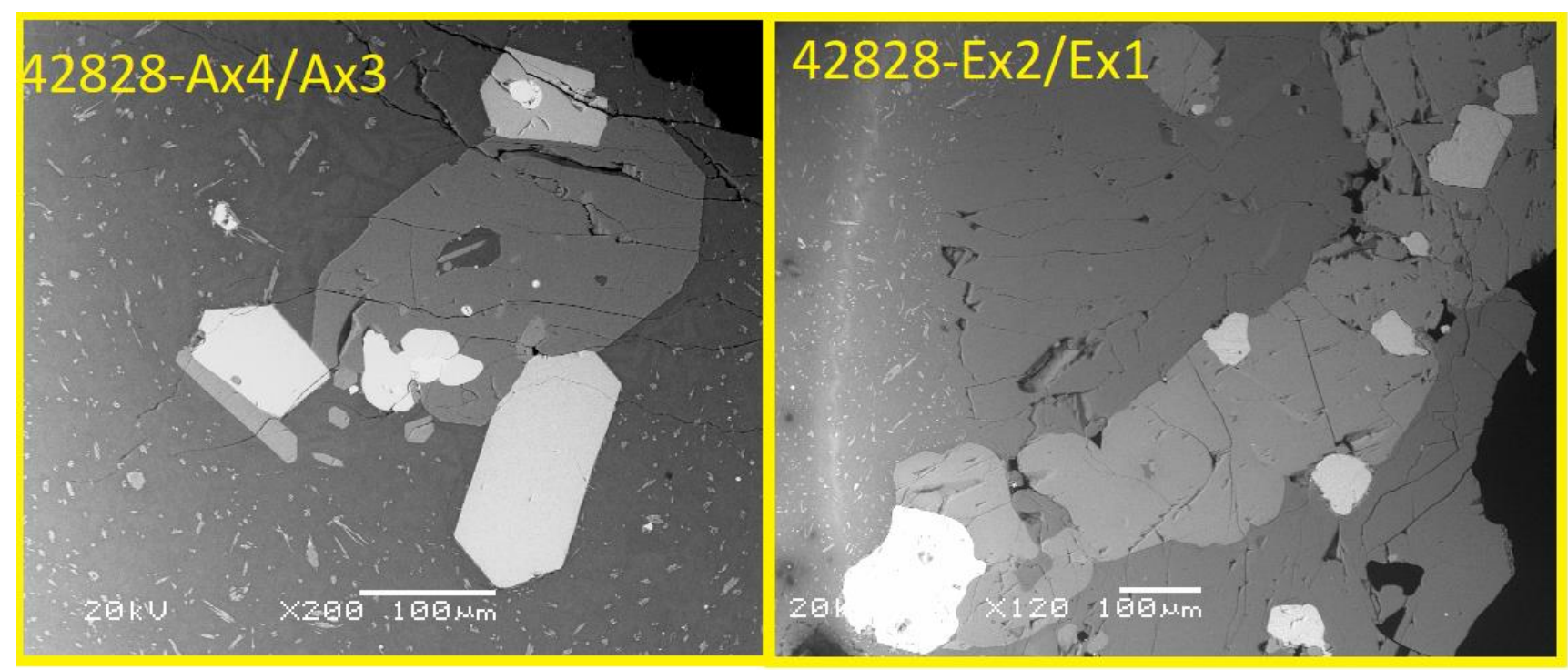




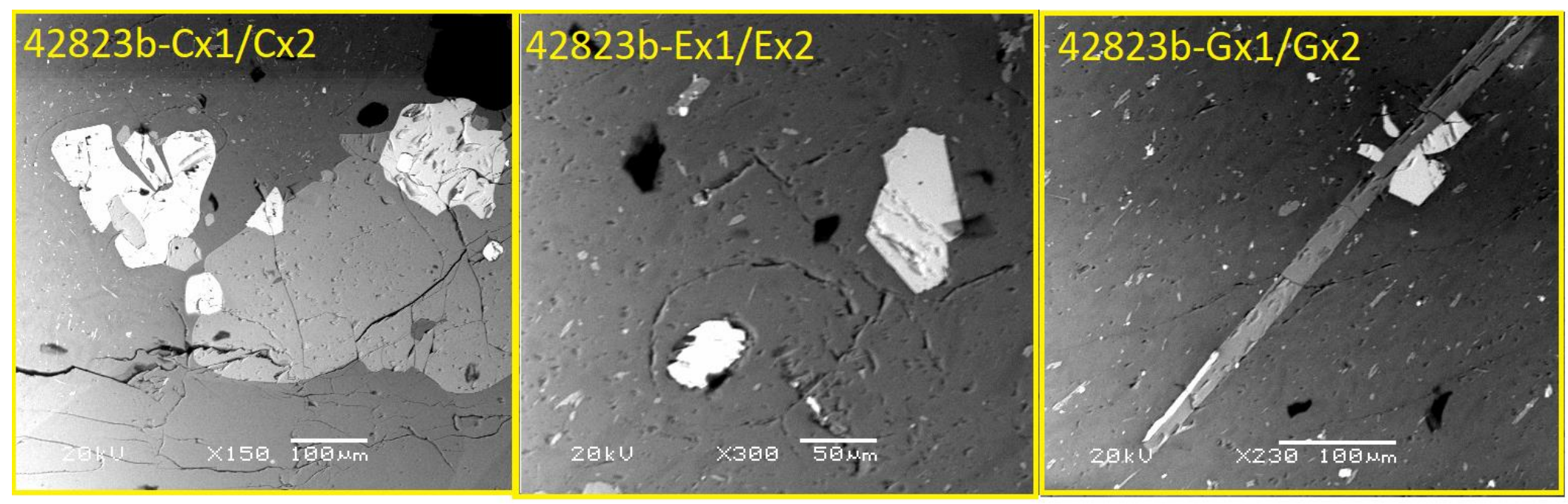


1960 EMPA oxide pairs images

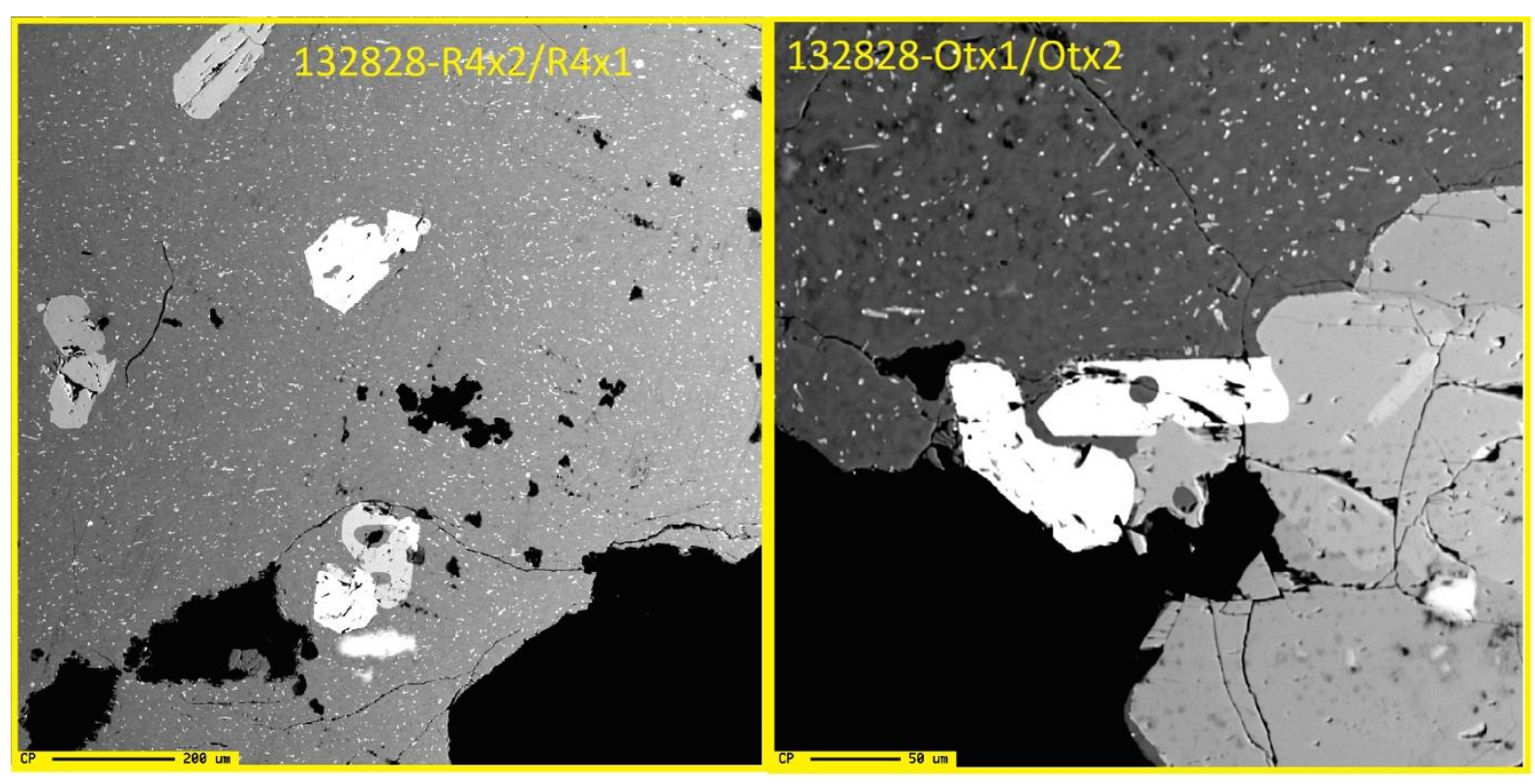


1960 SEM oxide pairs images

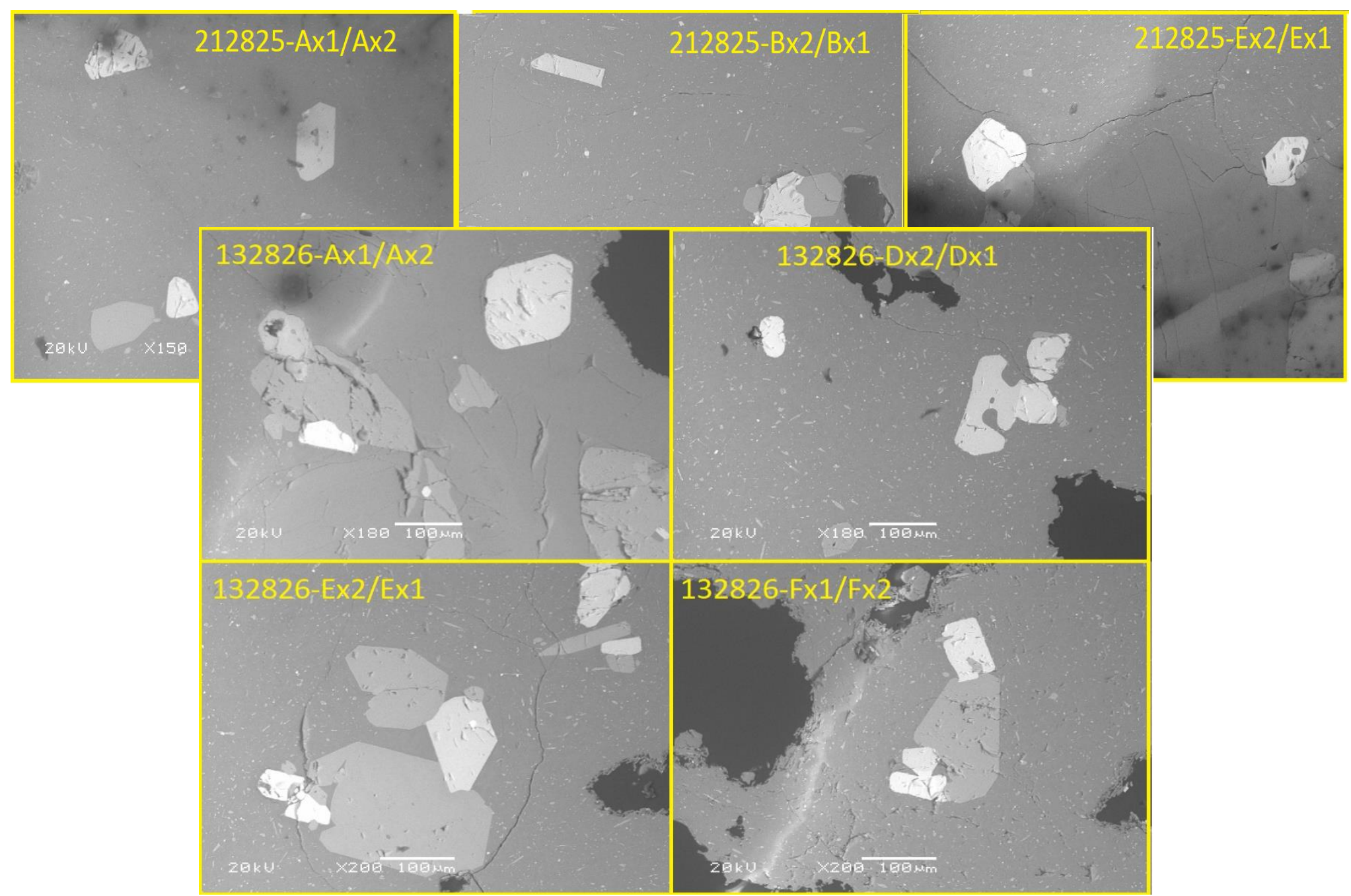



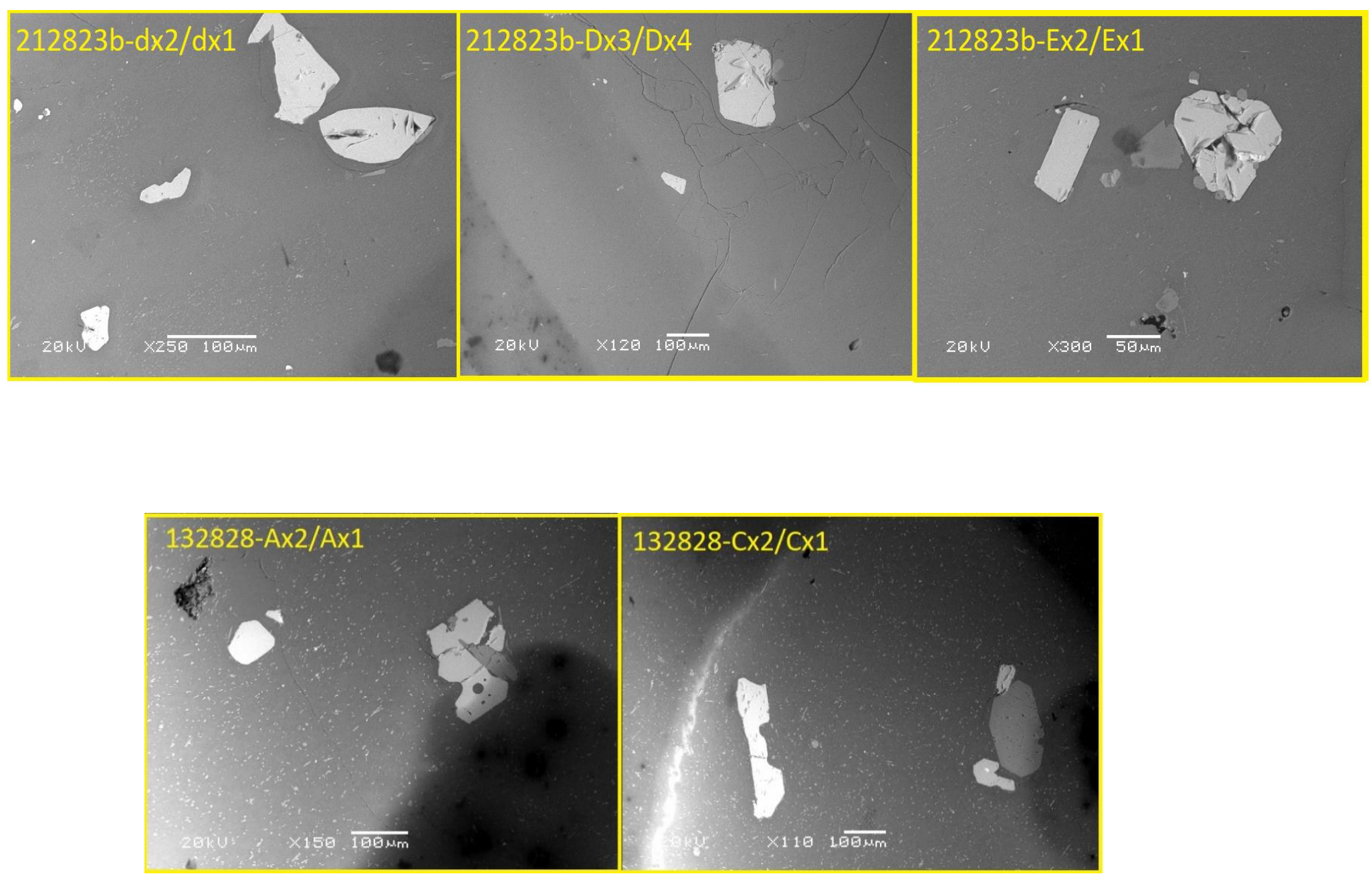


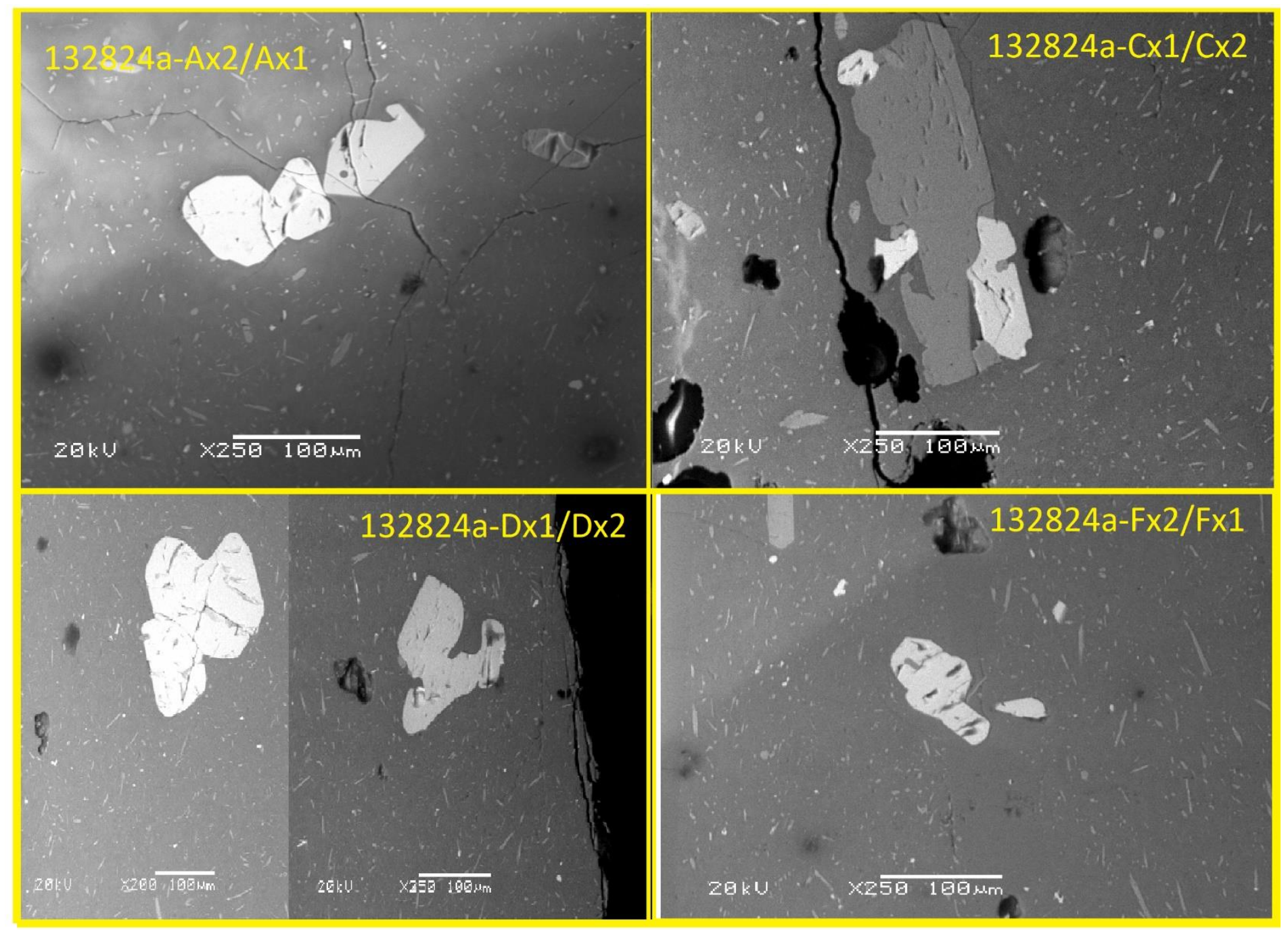


2011 EMPA oxide pairs images

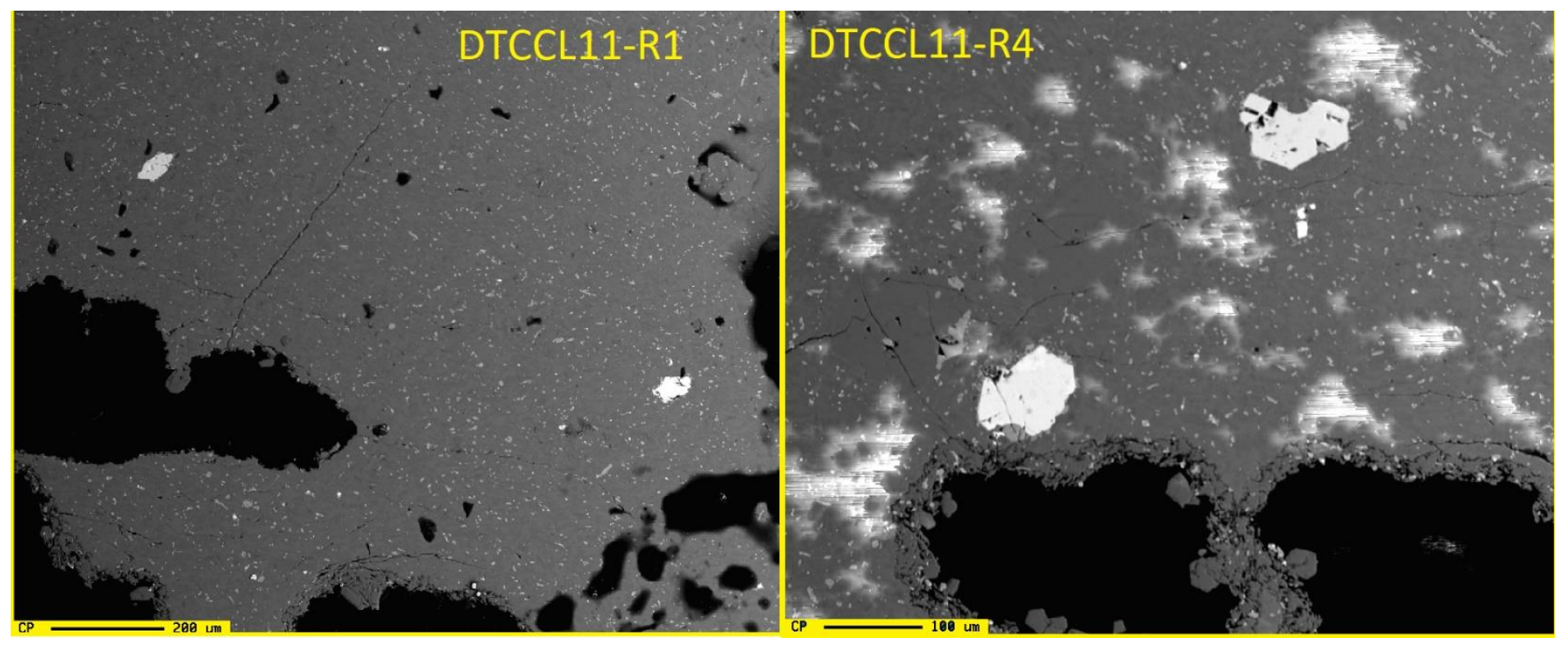




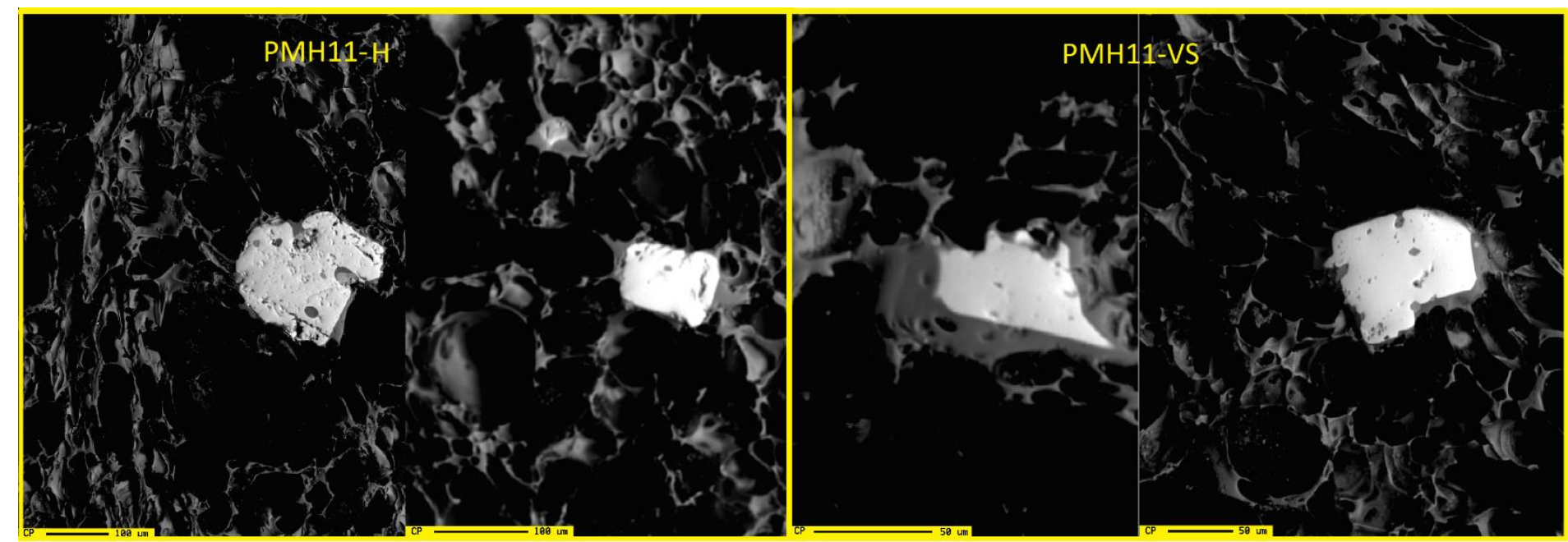

SEM oxide pairs Images 


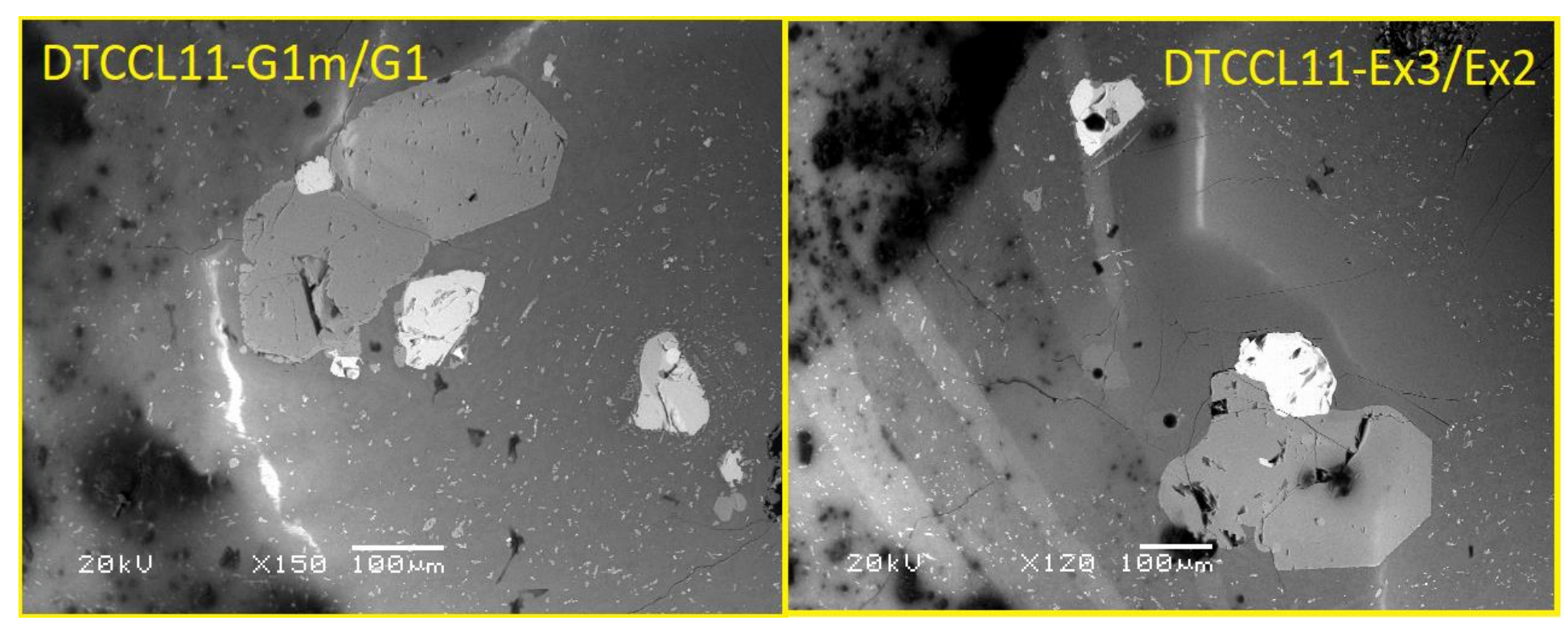




\section{Models used for variables values acquisitions}

\section{Thermometer for Fe-Ti oxide exchange (Ghiorso and Evans 2008)}

The model was used for the acquisition of pre-eruptive temperature and oxygen fugacity. This model was chosen because of the presence of the mineral phases that allowed said procedure. The two common Fe-Ti oxide phases present in intermediate and acid rocks are : rhombohedral oxides close to the ilmenite $\left(\mathrm{FeTiO}_{3}\right)$-hematite $\left(\mathrm{Fe}_{2} \mathrm{O}_{3}\right)$ and cubic oxides close to the magnetite $\left(\mathrm{Fe}_{3} \mathrm{O}_{4}\right)$ ulvospinel $\left(\mathrm{Fe}_{2} \mathrm{TiO}_{4}\right)$ if the phases are in equilibrium the temperature and oxygen fugacity can be acquired from following reactions:

1) $\mathrm{FeTiO}_{3}+\mathrm{Fe}_{3} \mathrm{O}_{4}=\mathrm{Fe}_{2} \mathrm{TiO}_{4}+\mathrm{Fe}_{2} \mathrm{O}_{3}$

2) $4 \mathrm{Fe}_{3} \mathrm{O}_{4}+\mathrm{O}_{2}=6 \mathrm{Fe}_{2} \mathrm{O}_{3}$

Equation "1" is used to estimate temperature and equation "2" for oxygen fugacity, both equations are combined in the model. For the model to work a proper calibration of activity and molar fractions of the elements is required.

The model is particularly useful for close to surface volcanic processes since the $\mathrm{Fe}-\mathrm{Ti}$ oxides have shown to recalibrate quickly in response to temperature and fugacity differences but the pressure plays a minor role since the volumes of the reactions is relatively low hence it does not affect the calculations in a significant way.

The estimated error can be up to 50 degrees Celsius but if the measurements are consistent 20 degrees is an acceptable standard error (Ghiorso and Evans 2008). As for the oxygen fugacity, the measurements are not sensitive 
to errors of instrumentation but there is a acceptable range at which the values are not too accurate tested in Blundy and Cashman (2009) the average absolute deviation is around $0.35 \mathrm{log}$ units for the NINiO buffer.

\section{Waters and Lange (2015) Hygrometer}

The Waters and Lange hygrometer/thermometer is based on the equilibrium of the following exchange reaction:

$\mathrm{CaAl}_{2} \mathrm{Si}_{2} \mathrm{O}_{8}{ }^{\text {crystal }}+\mathrm{NaAlSi}_{3} \mathrm{O}_{8}^{\text {liquid }}=\mathrm{CaAl}_{2} \mathrm{Si}_{2} \mathrm{O}_{8}$ liquid $+\mathrm{NaAlSi}_{3} \mathrm{O}_{8}$ crystal .

The crystalized phases interact with the magmatic liquid at a certain temperature and pressure therefore if the temperature is known the water content is the dependent variable of the following a regression equation: where $a, b$ and $\mathrm{X}_{\mathrm{H}_{2},}\left(-d_{\mathrm{H}_{\mathrm{O}}}\right)=x+a+\frac{b}{T}+\sum X_{\mathrm{i}} d_{\mathrm{i}} \quad \mathrm{C}$ are parameters used from calibration of experiments of plagioclase liquid equilibrium. And $x$ includes all the standard-state thermodynamic data, crystalline activity, and the ideal contributions to the liquid anorthite and albite activities. And finally, $X_{i}$ is for each oxide phase that contributes to the exchange reaction.

The model has a recommended range of $45-78 \mathrm{wt} \% \mathrm{SiO}_{2}$ in the liquid phase, and An15-95 for plagioclase compositions, with temperatures of $700-1300{ }^{\circ} \mathrm{C}$, and pressures of $0-1.2 \mathrm{GPa}$.

The Pressure is considered on the calculations but is important to note that the small volume change of the reaction leads to a minor influence on the resulting water content where an uncertainty in pressure of $\pm 100 \mathrm{MPa}$ only leads to an uncertainty of \pm 0.1 in the calculation of wt $\% \mathrm{H} 2 \mathrm{O}$. 


\section{Giordano (2008) pre-eruptive viscosity}

On the present study I use the model to estimate values for pre-eruptive viscosity, as a qualitative result, to understand the eruptive mechanics of the $\mathrm{CC}$ historic eruptions.

The model is used to predict viscosities values based on experimental measurements on over 20 years of data collection for rocks with accurately known compositions and temperature values. The model estimates the viscosity for most compositions ranges for known volcanic rocks, by considering a multi-component analysis, including the volatile species of $\mathrm{H}_{2} \mathrm{O}$ and Fluor, with an error of up to 0.45 log units pa.s. It is important to mark that the usage of the model does have its limits where the 3 major point are: 1) this model does not take into account the effect of pressure, even thou this variable does not have a big influence on the estimation, a correction based on the usage of this variable is an improvement to be made.

2) Not all the volatile phases are considered, for instance, $\mathrm{CO}_{2}$ is out of the calibration. 3) the iron oxide phase is used as total Fe therefore the effect of the different oxidation states is not accounted for. 